\title{
REPORTS RELATTING TO AFFAIRS IN THE DISTRICT OF COLUMBIA
}

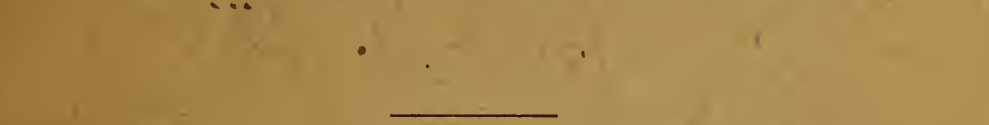

\author{
MESSAGE FROM THE \\ PRESIDENT OF. THE UNITED STATES •
}

TRANSMITTING REPORTS RELATING

TO AFFAIRS IN THE DISTRICT

OF COLUMBIA

December 17, 1908. - Read; referred to the Committee on the District of Columbia and ordered to be printed with accompanying papers and illustrations

\section{WASHINGTON}

GOVERNMENT PRINTING OFFICE 



\title{
REPORTS RELATING TO AFFAIRS IN THE DISTRICT OF COLUIBBIA
}

\author{
MESSAGE FROM THE \\ PRESIDENT OF THE UNITED STATES
}

TRANSMITTING REPORTS RELATING

TO AFFAIRS IN THE DISTRICT

OF COLUMBIA

Decenber 17, 1908. - Read; referred to the Committee on the District of Columbia and ordered to be printed with accompanying papers and illustrations

\section{WASHINGTON}

GOVERNIENT PRINTING OFFICE 



\section{To the Senate and House of Representatives:}

The rapid increase of population in the national capital within recent years has greatly altered social conditions, necessitating changes in the machinery of its administration. Greater efficiency and a better provision for the protection of both the industrial and dependent classes are required.

Recognizing these needs, I have had a special report made to me on the affairs of the District of Columbia, which I transmit herewith. I cordially approve the recommendations in the report for the substitution of a single head or governor in place of three commissioners, the establishment of District or municipal departments in place of the existing bureaus, and the creation of a new department to be known as that of housing and labor. I ask your careful consideration of the entire report. Mr. Reynolds has rendered a great and disinterested service, for which our heartiest thanks are due him.

A single executive head would increase efficiency, determine responsibility, and eliminate delays and uncertainties inevitable under the present system. Municipal departments headed by commissioners to be appointed by the governor would yield the same advantage.

In the proposed scheme of reorganization the department of education should be coordinated with other city departments.

I especially urge that the proposed department of housing and labor be established. Poverty, disease, and crime are largely due to defects of social conditions and surroundings. The need of improved sanitary inspection of dwellings, rear alleys, and small shacks (such as, unhappily, still exist in Washington), and of stores, workshops, and factories should not be left to subordinate burean chiefs, but should be brought under the direct control of a competent head of the above-named department.

An equally important public responsibility is the protection of the independent industrial class, which neither desires nor accepts charity, but whose members have often been led to misfortune, and even crime, through agencies licensed by the state, but defectively and inadequately supervised. Notable among these are pawnshops, loan and industrial insurance companies, and employment agencies. The supervision of these agencies is at present limited to the police. They should be under the direction of officials qualified to advance their efficiency and economic service to the public.

The above-named changes would vastly improve the efficiency of the District government, and would afford protection to its industrial and dependent classes which is imperatively needed.

I also transmit for the consideration of the Congress reports of the Committee on Building of Model Houses, which was appointed in accordance with the recommendation of Mr. Reynolds. 



\title{
RECOMMENDATIONS TO THE PRESIDENT REGARDING THE ADMINISTRATION OF THE AFFAIRS OF THE DISTRICT OF COLUMBIA.
}

\author{
By James Bronson Reynolds.
}

\section{The White Hodse, \\ Washington, February 24, 1906.}

Mr Dear Sir: In my message to the Fifty-ninth Congress at the beginning of the first session I said:

The National Gorernment has control of the District of Columbia, and it should see to it that the city of Washington is made a model city in all respects, both as regards parks, public playgrounds, proper regulation of the system of housing so as to do away with the evils of alley tenements, a proper system of education, a proper system of dealing with truancy and jurenile offenders, a proper handling of the charitable work of the District. Moreorer, there should be proper factory laws to prevent all abuses in the employment of women and children in the District.

To promote the above and kindred objects of good government I hereby request and authorize you to act as adviser (or special commissioner) to me, to investigate social conditions in the city of Washington and the administration of the city government in its abore-named relations to the people of the District of Columbia.

I wish your investigation to terminate in definite, practical recommendations to me with reference to the city's present needs and most notable defects measured by the highest standards of good administration in this country and elsewhere.

I will request that you present to me at your early convenience an outline of your plan of work, indicating the main lines of investigation which you find it practicable to undertake.

Very truly, yours.

James Bronson Reynolds, Esq.,

Theodore Roosevelt.

New York City.

The Highlands,

Washington, D.C., April 29, 190\%.

The President, the White Hocse,

Washington, D.C.

Sir: I present herewith my final report on the affairs of the District of Columbia. I sent to you last August my report on public education in the District, which was forwarded, under your instruction, to the board of education. The main points of the report were 
approved by the president of the board and the superintendent of education.

In your formal instructions to me you wrote: "I hereby request and authorize you to act as advisor (or special commissioner) to me, to investigate social conditions in the city of Washington and the administration of the city government. I wish your investigation to terminate in definite, practical recommendations to me, with reference to the city's present needs and most notable defects measured by the highest standards of good administration in this country and elsewhere."

It was my original plan to present a detailed programme relating to the various fields of municipal activity. My study of the situation, however, as well as the pressure of other work, determined me to make my suggestions of a more general character.

I wish to acknowledge most cordial and courteous cooperation from the District Commissioners in my work. I have also profited by the assistance and advice of many of the leading citizens of Washington, both white and colored, who have given much time and thought and aid to me, and who have expressed deep appreciation of your desire to improve conditions in the capital city.

Very respectfully,

(Signed) Jayies Broxson Reynolds.

\section{RECOMIMENDATIONS.}

CIVIL SERYICE.

No satisfactory standard of efficiency in the administration of the affairs of the District of Columbia can be secured until all minor officials are selected on merit and their retention in office and promotion depend solely on the quality of service rendered to the government. The District Commissioners on their own initiative have secured the examination by the Tational Civil Service Commission of all applicants for the police and fire departments. Medical officers and expert accountants are accepted only after a thorough competitive examination. The commissioners have also annually appealed for the extension of the civil-service law to cover all minor employees of the District, but this request has not been granted by the Congress.

The growth of the city and the increase of the number of its employees give each year added emphasis to the appeal of the District Commissioners for a well-regulated civil service. The general arguments in favor of the merit system are so well known and have so often been approved by you that I need not repeat them. I recommend that legislation be secured which will place all minor District appointments under the National Civil Service Commission.

EXECUTIVE ADMIINISTRATION.

The present administration of the affairs of the District of Columbia by three commissioners has the advantage of the intimate association and frequent conference of three executives of equal rank. But it has the inevitable defects of divided responsibility, confusion of authority, and of administration by a board instead of by a single 
responsible executive. While in certain respects the District has the government of a Territory, it is, in fact, a large city and its administration should conform to the methods adopted in other large cities in this country. After careful consideration of the subject and conference with many citizens of the District, and of other cities, I recommend a serious consideration of the substitution of a single chief executive for the present board of commissioners. For this official the title of governor has been suggested, as he would be governor of the District of Columbia as well as mayor of the city of Washington, the duties of both officers now devolving upon the three District Commissioners. He should receive compensation in proportion to the importance of the office and the arduous duties which it would impose.

I also recommend that eligibility for the office of governor be extended. Of the present District Commissioners "two must have been actual residents of the District for three years next before their appointment, and have during that period claimed residence nowhere else." The third is detailed from time to time from the Engineer Corps of the United States Army by the President of the United States. While residents of the District should naturally have preference, I believe the President should be free to consider the availability of successful and experienced mayors in other cities of the country who might be especially qualified to become the chief executive officer of the national capital.

It is, I think, generally recognized that the best governed cities of the world are those of Germany. In that country the mayors of the larger cities are selected from the mayors of smaller cities who have demonstrated their knowledge of municipal affairs and their executive efficiency. The present mayor of Berlin, for instance, served very successfully as mayor of two smaller cities before he reached his present position. The present mayors of Frankfort and Leipzig had also distinguished records as mayors in other cities. Those familiar with municipal progress in our country are aware of the increasing number of able municipal executives who are being developed in our large cities. Such executives at the end of one or two terms have no further opportunity for public service in the line of their successful experience. From them might be chosen an executive worthy of the high honor of being the chief executive of the national capital. I therefore recommend that eligibility be extended to include those who have served not less than one term as mayor in a city of not less than 50,000 inhabitants.

\section{ADMIINISTRATION OF CITY DEPARTMENTS.}

The present size of the District of Columbia imposes large and important responsibilities upon the different departments of its government and demands well-organized departments with efficient executive heads. For this reason, and in accordance with the suggestion of a single chief executive, I therefore recommend the establishment of the following departments under independent commissioners, to be appointed by the President upon nomination by the governor of the District of Columbia: Department of health, department of police and fire, department of street engineering, depart- 
ment of charities, department of corrections, department of buildings and public works, department of housing and labor.

As I have already presented to you a report regarding the department of education, and as that department has been recently reorganized by the Congress, I have thought it not wise to make any recommendations regarding it, until the present law has been more thoroughly tested, but I believe it should ultimately be brought within the proposed scheme of reorganization.

I did not include the finance and law departments in my plan of reorganization since my investigations have related primarily to problems of social reform. But I should hope that consideration would be given to the adoption of the standard system of public accounting now employed increasingly in our cities. The purpose of this system is the simplification of municipal accounts so that they may be more intelligible to the public and may furnish a basis for useful comparison between cities.

The guiding purpose in the plan of reorganization that I suggest is to define, locate, and centralize more exactly official responsibility, and to extend the power of the government of the District to better protect the health of its wage-earners and remove existing inequalities of opportunity. In the further presentation of this plan I wish to comment briefly upon the actual and proposed work of the various departments named above.

\section{The Department of Health.}

It has been urged by many citizens that this department, already rendering a valuable service, needs reorganization, increased efficiency, and an enlargement of its force. The number of working sanitary inspectors undoubtedly should be increased and the scope of the department extended.

\section{The Department of Police and Fire.}

The efficiency and good conduct of the Washington police department in the performance of regular patrol duty, and the excellence of its administration, seem to me to merit the high praise both have received. Police administration, however, in the large cities of the world has of late years extended its responsibilities beyond that of patrol service. The police force is no longer a band of civil soldiers to catch thieves and break up mobs. In the best governed cities of Europe the criminal division of the police service is a well organized detective bureau and is independent of the patrol division. Other bureaus have been added to regulate crowds, transportation, and traffic, to license cabs, carriages, express wagons, trucks, push-carts, street stands, shows, exhibitions, markets, etc. Some of these bureaus are already needed in Washington, and would locate responsibility and promote efficiency and good order in street service.

The need of a national police bureau of information at Washington has already been recognized by the commissioner and chief of are already needed in Washington, and would locate responsibility service to the whole country.

Even to meet adequately its present obligations of patrol service the police force should be enlarged. The commissioners have recom- 
mended to the Congress an increase in the number of patrolmen. To meet their recommendation, supported by numerous petitions for better protection, and to carry out the suggestions that I propose below, an addition of one hundred to the force is needed.

I suggest the establishment of the following bureaus under the police department:

\section{BUREAU OF TRANSPORTATION.}

This bureau should enforce all ordinances in relation to street traffic, licensing of cabs, carriages, express wagons, trucks, push-carts, street stands, and have care of lost articles. It should give particular attention to the enforcement of ordinances regulating the use of the public highway by carriages, trucks, automobiles, and bicycles. In the consideration of this subject I have had the aid of Mr. William P. Eno, who rendered raluable service in establishing the rules of the road in New York City. In a conference with him and with Commissioner West and Major Sylvester the importance of such regulations was recognized, and certain of them have already been put into operation.

I urge also a consideration of the introduction of taxameters to be attached to all cabs hired on the streets and at railway stations. I made a personal investigation of the use of taxameters in Berlin and Paris, questioning police officials, cab drivers, and citizens, and from all three had unqualified approval of them. The police stated that the adoption of taxameters had driven many dishonest drivers out of the cab service. The drivers declared that former conflicts between them and cab owners regarding the return of the full amount of fares had been eliminated, while citizens generally testified to the removal of irritating conflicts with cab drivers, formerly inevitable. I may add that the London authorities have recently voted to introduce the taxameter into that city, and that a private taxameter cab company has been organized in New York. I recommend that this important improvement in the cab service of the national capital be adopted. I am glad to state that Commissioner West is giving the subject consideration.

BUREAU OF THEATERS AND MARKETS.

This bureau should supervise all theaters, entertainment halls, common shows, and public markets, and see to the establishment and enforcement of all regulations concerning them.

\section{BUREAU OF IDENTIFICATION.}

The important work done by Major Sylvester in establishing a National Bureau of Identification of Criminals is worthy of the highest commendation. This bureau should be officially recognized and permanently established at Washington. I have had occasion to examine the workings of the national police bureaus at Vienna, Berlin, Paris, and London. The service rendered by these bureaus as a national clearing house for the identification of criminals has been of great value to law and order in these countries.

I wish in this connection to urge the consideration of the fingerprint system of identification now employed in England, Austria, and 
some of the British colonies, and recently adopted in several cities in this country. The testimony of officials in these countries and cities is to the effect that this system facilitates and simplifies the identification of criminals, secures more accuracy than the cumbrous system of measurements, and has enabled the police to identify a far larger percentage of suspected criminals than formerly.

\section{The Department of Buildings and Public Works.}

This department should supervise all public buildings and enforce laws and ordinances in relation to the construction and safety of private buildings, and should control all public works such as sewerage, lighting, and water supply.

\section{The Department of Charities.}

The present board of charities has performed a service of the highest value. The gradual reduction through its efforts of the number of subsidized charities has been a difficult and often thankless task. It would seem to me, however, that the time has now come when the place of this board should be taken by a commissioner of charities, who would give constant supervision to the charitable institutions maintained by the District or for which District funds are approprated. If you judge it preferable to continue the board of charities I would recommend that the president of the board be a salaried commissioner, giving his entire time to the work. It is to be hoped that in the near future no hospitals or charitable institutions will receive subsidies from the Congress unless such subsidies are indorsed by the board of charities or by the commissioner of charities, if this office be constituted.

\section{The Department of Corrections.}

An independent department of corrections is needed under the presidency of a competent, well-salaried executive. Such department should have charge of all penal and corrective institutions in the District, and penal institutions of the National Government now located in the District should be turned over to it.

The children's court recently established with probation service is meeting with general approval as a step in the right direction in the more intelligent handling of juvenile offenders. Such department of corrections should make a careful examination of all corrective institutions in the District, with a view to secure and apply such corrective methods as shall tend to educate criminals out of crime, and not as has been the history of penal institutions in the past, drive them more deeply into it.

\section{The Department of Street Engineering.}

This department should have charge of the construction, paving, and repairing of all streets, highways, and sidewalks, cleaning of the same, and the disposal of ashes and garbage. I am aware that it is customary to place the construction and repair of highways under one department, and their cleaning under another, but in my opin- 
ion it would locate responsibility more clearly and increase the intelligence and efficiency of administration to place the construction and care of the streets under one department.

\section{ViI. The Department of Housing and Labor.}

The present government of the District contains no adequate means for the collection of information in relation to housing and labor. The special supervision of their poorer quarters established in some cities, and the bureaus of labor found in most States, are also lacking. The office of the commissioner of insurance might also be organized into a bureau and appropriately, included in this department.

To meet the above requirements, I suggest that the following bureaus be constituted under this department:

BUREAU OF STATISTICS.

This bureau should obtain and publish information on such matters as child labor, women's labor, pawn shops, industrial insurance and other forms of industrial savings, hours and conditions of labor and other matters relative to the condition and welfare of wageearners. It should also collect and publish reports on housing and allied problems of the District.

BUREAU OF HOUSING.

This bureau should enforce the laws regarding tenements, small houses, alley shacks, and alleys. The recent experience of the New York City tenement house department shows that the supervision of these houses by a special department defines responsibility and brings better results than when a general building department controls all classes of private buildings.

BUREAU OF LABOR.

This bureau should have the oversight of pawnshops, loan companies, employment agencies, and the enforcement of laws relating to factories, work-shops, and stores. Such a bureau is greatly needed for the sake of all who resort to the various agencies above named, and for all those, including women and children, who should have the protection of adequate factory laws.

Pawn shops and loan companies are a necessity to people of limited means, but the former, as well as the latter, always require careful inspection. I am told that the loan companies, as they exist at present, have been the undoing of many in the public service at Washington.

The adjustment of the supply and demand of labor is of the highest importance. The public machinery for this adjustment is licensed employment agencies, which should have far more serious consideration in this country than they receive at present. A careful canvass of employment agencies of the District of Columbia last spring indicated that these agencies are no better, and probably no worse, than those of other cities, but their value is far below what it might be to their patrons, both employers and employees. They 
require more than mere police inspection, and should have especially qualified supervision to prevent abuses and to enlarge their utility.

The growth of the national capital and the increase of trade and manufacture necessitate proper factory and shop laws and definite responsibility for their enforcement.

BUREAU OF INSURANCE.

In place of a commissioner of insurance, with one or trio clerks, a fully organized bureau with a chief and adequate staff is needed. Particular attention should be given to the economic effects of industrial insurance, while other means of saving, such as banking, insurance, and postal savings, should properly come under the attention and inspection of the bureau.

It will be noted that I have made no detailed comment on the fire department beyond combining it with the police department. I have also made no comments on other existing departments, except where such comments were required as a basis for recommendations. In my survey I have found several isolated offices in the District government; such as coal inspector, inspector of weights and measures, and sanitary inspector. These offices should be joined to some appropriate department above named, to whose commissioner they should be responsible.

\section{MUNICIPAL ORDINANCES.}

In the absence of municipal council or territorial assembly, the power to díaft ordinances has been in the hands of the District Commissioners. Under the proposed plan regulations for the administration of departments might properly be intrusted to the executive head of such departments. The power to pass general ordinances might best be given to a council composed of the commissioners at the head of the various departments of the District government. Sessions of the council should be public, and ordinances when passed should be subject to the approval of the governor, after notice in the daily press of the passage of such ordinances and after public hearing.

It would be greatly to the advantage of the District and relieve the National Congress of unnecessary burdens of District administration if larger powers were granted both to the executive and legislative departments of the District government.

\section{CIVIC INTEREST IN THE DISTRICT OF COLUMIBIA.}

The importance of the service of civic organizations in the District of Columbia is emphasized, not diminished, by the absence of the right to vote. On the material side such service is rendered by the board of trade, the business men's association, the jobbers and shippers' association, and rarious sectional associations. These organizations have also shown an interest in the general civic concerns of the District. There does not, however, exist any strong organization charging itself primarily with the disinterested promotion of the general public welfare. Such an organization is greatly needed, and I suggest the propriety of your naming a committee of 100 to be composed of representatives of all elements and to express the varied 
interests of the District in relation to all questions of social reform and administration. It would differ from commercial organizations, whose primary interest is material and personal, in that its primary interest would be civic and general. The recommendations of such a body would undoubtedly have weight with yourself, with the Congress, and with the administrative officers of the District, and its conferences would furnish a forum for discussion and the expression and enlightenment of public opinion.

My recommendations summarized are the following:

1. The extension of the civil service to cover all minor offices in the District of Columbia.

2. The creation of the office of governor, at a salary of perhaps $\$ 10,000$ per annum.

3. The creation of departments of health, police and fire, buildings and public works, street engineering, charities, corrections, and housing and labor. These departments should be conducted by a commissioner at a salary of perhaps $\$ 5,000$ per annum.

4. A municipal council, composed of the above-named commissioners, should constitute a public assembly for the passage of ordinances regulating the affairs of the District.

5. A citizens' committee of 100 to represent all general civic interests.

Respectfully submitted.

JaMes Bronson Reynolds.

RECOMMENDATIONS REGARDING THE PUBLIC-SCHOOL SYSTEM OF THE DISTRICT OF COLUMBIA.

In investigating the public-school system of the District of Columbia, as directed by you, I have considered it from the point of view of the educational, social, and civic needs of the community rather than from that of the educational expert. I have, therefore, not attempted to criticise the methods of instruction, discipline, building construction, and school administration that obtain.

I have examined the Report of Hearings before the Subcommittee on the Several School Bills Relating to the Reorganization of the Schools of the District of Columbia during the long session of 1906 , the annual reports of the Commissioner of Education, the Report of the Board of Education to the Commissioners of the District of Columbia for 1903 and 1904, the Report of the Committee on Salaries, Tenure, and Pensions of the Public School Teachers in the United States, of the National Educational Association. July, 1905, and I have had many interviews with some of the best-informed men and women of the District, both white and colored, regarding its publicschool system.

The passage of the school reorganization bill at the last session of the Congress remores the necessity of considering certain problems relating to the public schools of the District, since various questions have been settled, at least for the present, and the changes required by the new law are yet to be tested.

In my recommendations I call attention to the provisions for the physical welfare of the children, believing that the first purpose of education should be the development of a sound body. 
I consider the supplementary uses of school buildings, calling attention to those found to a much less extent in the schools of Washington than in those of other large cities of our country.

I urge a large increase in school accommodations, an increase rendered imperative by the passage of the compulsory education law. The reorganization of the board of education makes timely the consideration of the much-criticised system of school supervision.

I am glad to record the successful development of the high schools, noting the importance of constant expansion.

I have examined the statistics of attendance. These reveal a startling decrease in attendance, from the lowest grades of the primary schools to the entrance grades of the high schools.

The fact that a great majority of the school children get no further than the grammar grades demands in my opinion a rearrangement of the primary and grammar grades so that a more wisely adjusted course of training may be provided.

My recommendations are as follows:

First. The physical melfare of the school children should receive more attention. Every school should have a playground, gymnasium, and shower bath. At present but few schools in the District have all of these provisions, and many have none of them. The exercise ground, the gymnasium, and the baths should be used under competent direction. This work should be as much a part of the school system as that of the class room. The playground, the gymnasium, and the baths should also be available in summer wherever there is need of them.

Second. The public-school buildings should be more extensively used. The night-school and public-school systems, which have already accomplished excellent results, should be extended. Literary societies, debating clubs, and other organizations seeking to promote the intellectual and social welfare of their members should be allowed the use of school buildings at a rental which would cover the expense of care and lighting. Such use of school buildings is now made in New York, Boston, Philadelphia, Chicago, and many other cities.

Third. A careful examination of the system of supervision of the schools is needed, in view of frequent criticisms to the effect that it is cumbersome, inefficient, and not economical.

Fourth. A large increase in the number of sittings is imperatively needed. According to the census made by the police during the last school year about 700 children are out of school. According to other authorities the number is about 7,000. The latter estimate is probably nearer the truth, as shown by a careful canvass of certain sections of the city undertaken subsequently to that made by the police.

Fifth. The status of the high, manual-training, business, and normal schools appears to be excellent, but there is a steady demand for the enlargement of the manual-training and commercial schools which should receive prompt attention. The most pressing need of these schools in the recent past, an increase in the salaries of the teachers, has been remedied by recent legislation.

Sixth. The compulsory attendance law should be strictly enforced, and parents should be urged to keep their children at school through the entire primary course and also through the grammar course when possible. According to the last annual report of the board of educa- 
tion there were in the first grade of the primary school 9,126 children. In the first high-school grade there were 1,822, a difference of 7,304 . From this it appears that only one-fifth of the children who enter the primary school reach the high school, and the entire benefit derived from the public schools by four-fifths of the children of the District is that furnished by the primary and grammar grades. It is also to be noted that there is a rapid decrease in attendance through the successive grades of the primary and grammar schools.

Seventh. The training of the children in the primary and grammar grades should be more practical. Instruction in reading, writing, and arithmetic is of permanent value, but it must not be forgotten that four-fifths, and possibly nine-tenths of the children who discontinue their education at the end of the primary or grammar grades will, if boys, earn their livelihood with their hands, and if girls, be their own housekeepers, seamstresses, and cooks. Girls should be taught plain sewing and plain cooking, and boys some of the simple forms of manual labor. Ten years of experience in New York City, when I was in constant touch with the problems of poverty and, part of the time, a school official, convinced me that those children who pursue exclusively the literary and semiliterary courses are little inclined to manual labor, and are not equipped for it. If forced by circumstances to such labor, as they usually are, they undertake it unwillingly, without pride in their work and without skill. A majority of the cases of extreme poverty due to the inability of the wageearner to obtain employment arise from his lack of any technical training. It seems to me sound public economy for the school to give its boys elementary industrial, as well as elementary commercial, training.

It has been sometimes urged that free soup and free lunches should be provided by the schools because of the half-starved condition of many of the school children. My examination of the subject leads me to believe that there is far more starvation due to badly selected and badly prepared food than to actual lack of food. In other words, the ignorance of the mothers regarding cooking and the nutritive value of foods is more frequently the cause of physical weakness than actual hunger.

The need of industrial training is emphasized by an examination of the report of the Metropolitan Police department for the year 1905. It states that 1,762 children under 16 years of age were arrested in the preceding year, of which number 1,427 were penalized or restrained. Nearly all the offenses charged were those likely to spring from idleness rather than from criminal disposition. My examination of the tenement and dwelling houses of the poor in the District showed me that large numbers of boys and girls are out of school and out of work. Conversations held with some of them showed that they had had no training for any special occupation. I submit that it would be less expensive for the District to train these children than to maintain houses of detention to punish them for misconduct during idleness, of which they are the victims quite as often as the cause.

Respectfully submitted. 
REPORT ON THE HOUSING OF THE POOR IN THE DISTRICT OF COLUMBIA, ESPECIALLY IN RELATION TO INSIDE TENEMENTS.

As you directed me to give particular attention to the housing problem, I visited and examined between 350 and 400 tenements, shacks, and small houses in various sections of Washington and Georgetown, and inspected numerous alleys. I talked with their occupants and conferred with many citizens of the District, both white and colored, including representatives of trade unions, to obtain their views regarding housing conditions.

In my investigations I found three distinct problems, that of small houses, that of alley shacks and alley houses, and that of inside alleys. There are some, perhaps many, good houses for wage-earners in Washington, but the laws and ordinances in relation to their construction are defective and incomplete, and need thorough revision. For instance, one ordinance requires that every sleeping room in a tenement or lodging house must have at least 400 cubic feet of space for each occupant above 10 years of age, but fails to place any limitation upon the number of occupants under 10 years who may sleep in such room. Hence, while but four adults might occupy a room containing only 1,600 cubic feet of space, any number of children under 10 might occupy the same room without violating the ordinance.

A second ordinance provides that hallways of tenements shall be properly lighted at night, but does not exact that such hallways shall, whenever necessary, be lighted during the day. I saw many dark hallways which required light during the day quite as much as during the night.

An ordinance passed by the District Commissioners, which went into effect December 1, 1905, marks progress in limiting the building space of an interior lot 75 per cent of its area, and of a corner lot to 90 per cent, but many other defects indicate the need of a thorough revision of the existing Code.

I found nearly all the alley wooden shacks and small brick houses that I visited in a wretched condition. The wooden shacks, as a rule, might properly be condemned on structural grounds. Their yards were apparently storage places for refuse and filth, their water supply inadequately and badly placed, and the privies frequently only open boxes, and in many instances without covers, although the latter are required by the health ordinance. I am glad to state that during the past year many of these box privies have been removed.

I had conversations with the dwellers in these inside shacks, and the comments of many may be fairly summarized in the pathetic remark of an old colored woman who exclaimed, with reference to her neglected, filthy yard and privy, "Why, my old marsa wouldn't ha' kep' his horses stabled in such a place."

No argument is needed to show that such ill-conditioned hovels are culture beds of disease, the germs of which may be carried far and wide by the flies which feed on the rotting garbage and excreta. Their number should be promptly ascertained and immediate steps taken for their complete elimination, and buildings constructed in their places should have proper sanitary appurtenances, and should open either upon a highway or small street.

In a few instances the dwellers in these shacks would probably merit temporary help in securing better quarters if the shacks were 
destroyed, but if the abolition of the shacks should result in driving their tenants from the city, an undesirable element of its population in many instances, and at present an expense to the city through its police courts and prisons, would be removed.

The small brick houses inside the squares are not usually in as unsatisfactory a condition as the wooden shacks, but a large percentage of them are withont adequate water supply and proper privies, and are often structurally defective.

A particularly undesirable and menacing feature of the poor quarters of Washington is the inside alleys. These alley are centers of disorder and crime, and they make possible the continuance of small communities uncontrolled by ordinary police inspection and unaffected by public observation and criticism. In my opinion all inside alleys, with the exception of service alleys, should be abolished, and a definite scheme for the accomplishment of this object should be adopted. While I must record these conditions as I witness them, I am glad to bear testimony to the work done since the passage of the act for the condemnation of unsanitary buildings. The board for the condemnation of unsanitary buildings was formed under this act July 1, 1906. Since that date 61 houses in alleys have been demolished and 73 houses on streets, while 7 have been repaired in alleys and 17 on streets. The condition of the alleys and the activity of the health officers is indicated by the fact that from July 1, 1905, to June 30,1906 , the sanitary inspectors reported 342 alleys in filthy condition.

A law passed by the Congress in 1906 appropriated $\$ 50,000$ for the expense of condemnation proceedings in the substitution of minor streets for alleys, but a recent decision of the supreme court of the District of Columbia has interposed fresh difficulties by declaring unconstitutional the assumption of the law that the entire cost of opening small streets as substitutes for alleys should be assessed upon the adjacent property owners. I am not prepared to make any specific recommendations to meet this new difficulty, but urge that it be not allowed to prevent the abolition of inside alleys.

For the proper inspection of small houses, shacks, and alleys, a large and efficient force of building and sanitary inspectors is neces- sary. Two additional inspectors will be available July 1, 1907, but these are not sufficient.

The pressure of regular work, the details of administration, and the amount of time required each session in preparing and presenting information to Congress make it extremely difficult, in my opinion, for the District Commissioners to give to the housing problem the time and serious attention which it demands.

Your message to the Congress on December 1, 1904, the experience of other communities, and the conditions which I have reported indicate the value of the appointment of a special commission to consider the housing problem of the District of Columbia. Recent housing commissions in other cities have not only considered questions of building construction and sanitation, but many other matters affecting the physical, social, and moral welfare of the dwellers in small houses. Questions of building, construction, and sanitation are being considered by the building commission appointed by the District Commissioners, and action on these lines may be safely

S. Doc. 599, 60-2 - 2 
delayed until this commission has reported and its report has been acted upon by the District Commissioners. On the other hand, there are many questions affecting the welfare of the dwellers in small houses which should receive the attention of a housing commission. Such are, among others, the need of recreation grounds and public baths, remedial agencies for the immoral life in the alleys, and agencies for social betterment, such as industrial education, the free public library, and the encouragement of the excellent system of model workingmen's dwellings, similar to those built by the Washington Sanitary Housing Company. This wide field merits attention from the broad point of view of social betterment, with the home, and not merely the house, as the subject of fundamental interest. I therefore recommend the appointment of a commission to be known as "The President's homes commission." If this recommendation meets your approval, I would make the following suggestions regarding it:

First. The President's homes commission should be composed of $1 \check{2}$ members, to include among others an architect, a real-estate dealer, a practical builder, and two representatives of trade unions.

Second. That the commission should be instructed to ascertain and consider the results of the best efforts of public enterprise and private philanthropy to improve the homes and better the lives of the industrial classes in other cities in the country.

Third. It should be instructed to invite the cooperation of all having interest in the housing problem and the home problem in the District, and before presenting its final report it should give public hearings on the main points of its programme so that all just criticism might be heard.

Fourth. It should be advised to recommend, so far as possible, reforms which may be accomplished by your executive order or by the action of the District government.

Fifth. The commission should serve without compensation and all expenses incurred should be borne by voluntary contributions.

The task of preparing a satisfactory housing code, of the rearrangement of the building space within the large squares of the District of Columbia, and of bettering the physical, moral, and social condition of the industrial classes, needs the serious consideration of such a body, and its work would be productive of wide-reaching and permanent benefit to the District. Thus the homes of the poor might have a consistent place in the fair aspect of the nation's capital.

Respectfully submitted.

\section{Jayes Bronson Reynolds.}

In accordance with the recommendations contained in the abore report the President appointed the following commission to be known as the President's Homes Commission:

Gen. George M. Sternberg, chairman.

Adams, Emmett L.

Baldwin, William $\mathrm{H}$.

Boardman, Miss Mabel $\mathrm{T}$.

Prennan, Patrick J.

Cook, George William

Iowney, Wiliam F.

Gaff, Mrs. Thomas T.
Kober, George M., M. D.

McKinlay, Whitefield.

Parsons, T. C.

Reynolds, James B.

Siddons, F. L.

Sleman, John B., jr.

Woodward, S. W. 


\section{PRELIMINARY REPORT OF THE PRESIDENT'S HOMES COMMISSION.}

The letter of the President designating the membership of the commission is as follows:

The Winte House,

Washington, May 4, 190\%.

I inclose you a copy of the report made to me by Mr. James Bronson Reynolds. In pursuance of the recommendations therein made, I have decided to designate a commission of 15 persons, as follows:

Gen. George M. Sternberg.

Dr. George M. Kober.

Mr. William H. Baldwin.

Mr. Frederick L. Siddons.

Prof. George W. Cook.

Mr. Whitefield McKinlay.

Miss Mabel T. Boardman.

Mrs. Arnold Hague.

Mr. James Bronson Reynolds.

Mr. S. W. Woodward.

Mr. John B. Sleman, jr.

Mr. T. C. Parsons.

Mr. Emmett L. Adams.

Mr. P. J. Brennan.

Mr. William F. Downey.

Can you serve as a member of this commission for the purpose indicated? I earnestly hope that you can accept, as it seems to me that this commission has before it a large field of usefulness.

Yours, sincerely,

Theodore Roosevelt.

All of the persons named accepted membership upon this commission except Mrs. Arnold Hague. Mrs. Thomas T. Gaff was subsequently named by the President to fill this vacancy.

The report of Mr. James Bronson Reynolds, referred to in the President's letter as the basis of his action, is as follows:

\section{REPORT ON THE HOUSING OF THE POOR IN THE DISTRICT OF COLUMBIA, ESPECIALLY IN RELATION TO INSIDE TENEMENTS.}

As you directed me to give particular attention to the housing problem, I visited and examined between 350 and 400 tenements, shacks, and small houses in various sections of Washington and Georgetown, and inspected numerous alleys. I talked with their occupants and conferred with many citizens of the District, both white and colored, including representatives of trade unions, to obtain their views regarding housing conditions. 
In my investigation I found three distinct problems, that of small houses, that of alley shacks and alley houses, and that of inside alleys. There are some, perhaps many, good houses for wage-earners in Washington, but the laws and ordinances in relation to their construction are defective and incomplete, and need thorough revision. For instance, one ordinance requires that every sleeping room in a tenement or lodging house must have at least 400 cubic feet of space for each occupant above 10 years of age, but fails to place any limitation upon the number of occupants under 10 years who may sleep in such rooms. Hence, while but four adults might occupy a room containing only 1,600 cubic feet of space, any number of children under 10 might occupy the same room without violating the ordinance.

A second ordinance provides that hallways of tenements shall be properly lighted at night, but does not exact that such hallways shall, whenever necessary, be lighted during the day. I saw many dark hallways which required light during the day quite as much as during the night.

An ordinance passed by the District Commissioners, which went into effect December 1, 1905, marks progress in limiting the building space of an interior lot to 75 per cent of its area and of a corner lot to 90 per cent, but many other defects indicate the need of a thorough revision of the existing Code.

\section{INSANITARY HOUSES IN THE ALLEYS.}

I found nearly all the alley wooden shacks and small brick houses that I visited in a wretched condition. The wooden shacks, as a rule, might properly be condemned on structural grounds. Their yards were apparently storage places for refuse and filth, their water supply inadequate and badly placed, and the privies frequently only open boxes and in many instances without covers, although the latter are required by the health ordinance. I am glad to state that during the past year many of these box privies have been removed.

I had conversation with the dwellers in these inside shacks, and the comments of many may be fairly summarized in the pathetic remark of an old colored woman who exclaimed with reference to her neglected, filthy yard and privy, "Why, my old marsa wouldn't ha" kep' his horses stabled in such a place."

No argument is needed to show that such ill-conditioned hovels are culture beds of disease, the germs of which may be carried far and wide by the flies which feed on the rotting garbage and excreta. Their number should be promptly ascertained and immediate steps taken for their complete elimination, and buildings constructed in their places should have proper sanitary appurtenances and should open either upon a highway or small street.

In a few instances the dwellers in these shacks would probably merit temporary help in securing better quarters if the shacks were destroyed; but if the abolition of the shacks should result in driving their tenants from the city, in most instances an undesirable element of its population, which is at present an expense to the city through its police courts and prisons, would be removed. 


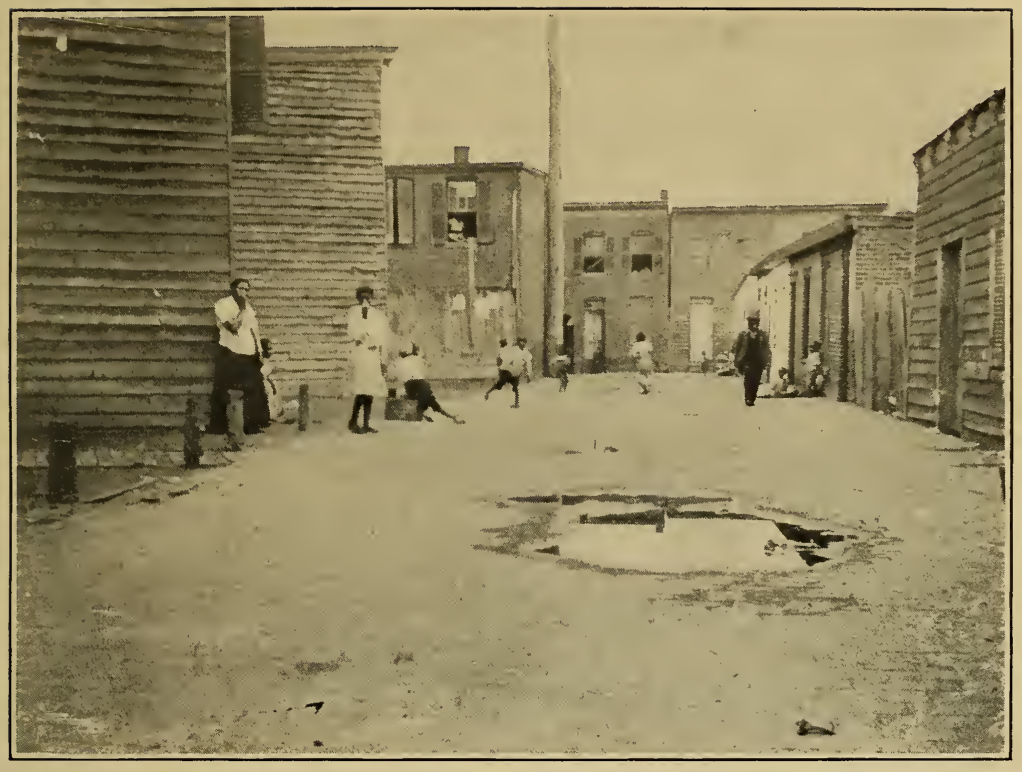

FIG. 5.-TYPICAL ALLEY HOUSES IN NORTHEAST WASHINGTON.

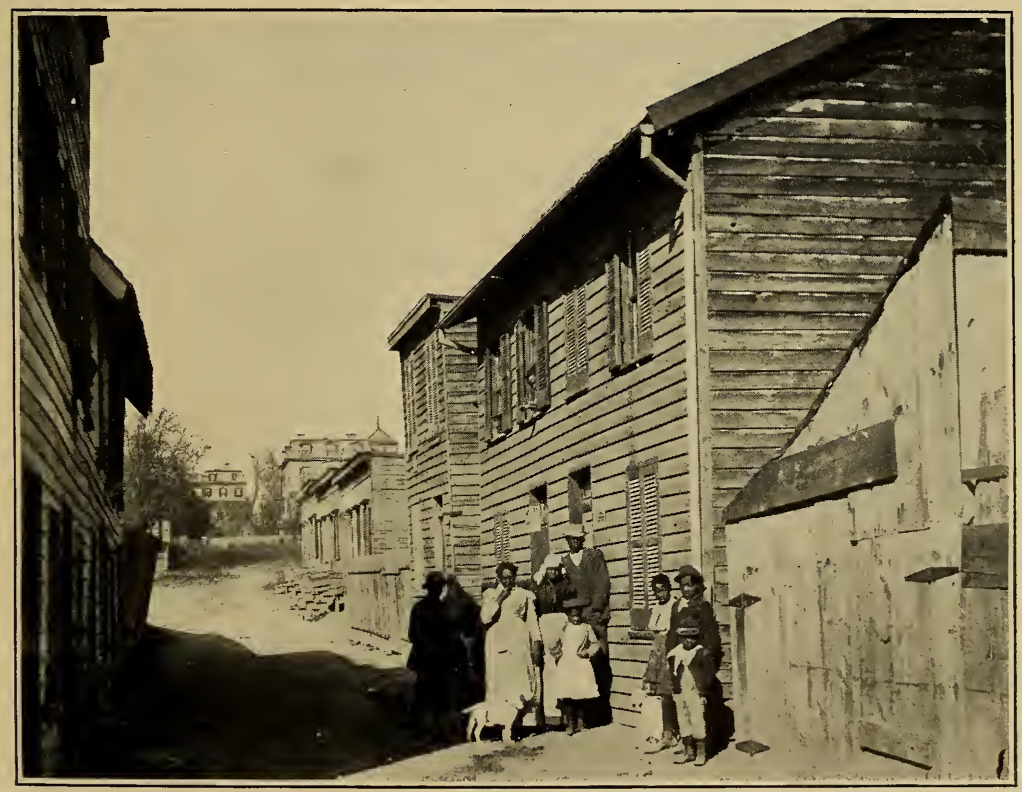

FIG. 6.-ALLEY HOUSES IN NORTHWEST SECTION OF THE CITY - "SHADD ROW." 



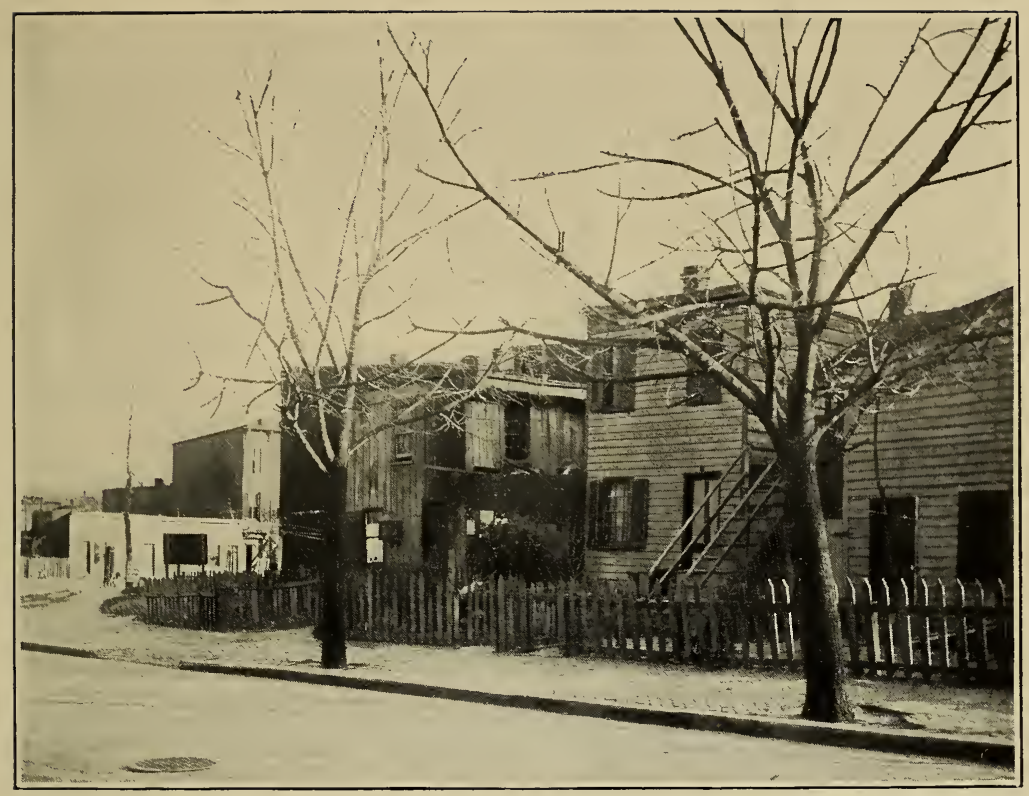

FIG. 7.-OLD FRAME HOUSES ON ELEVENTH STREET NORTHWEST

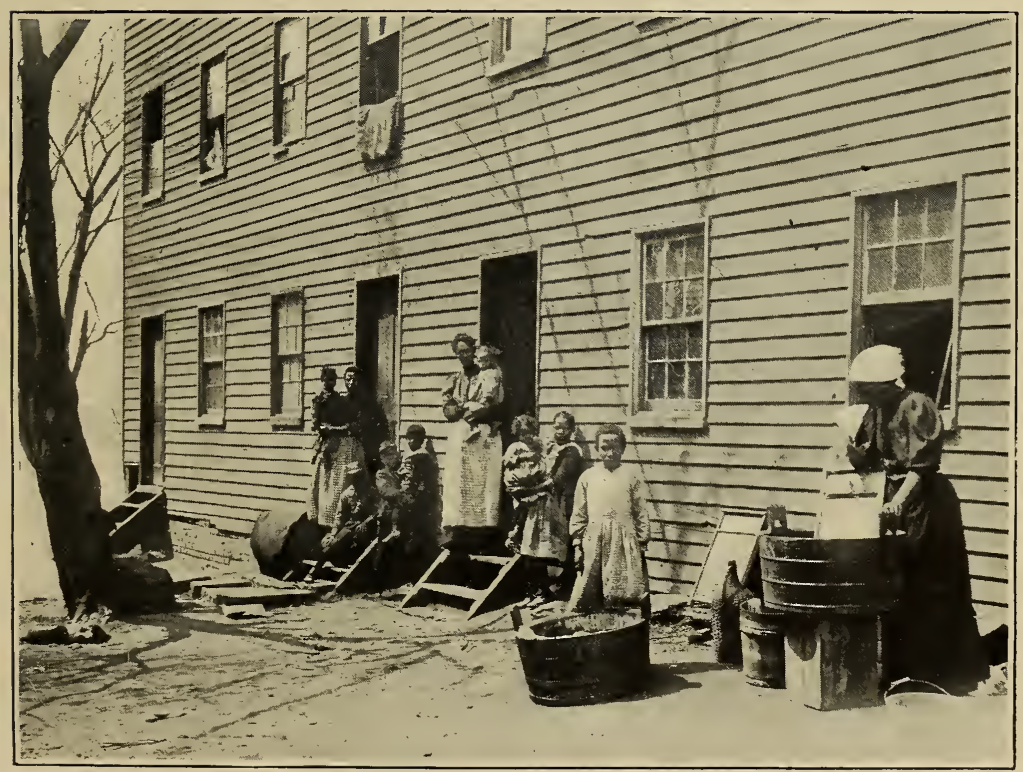

FIG. 8.-TYPICAL ROW OF FRAME HOUSES. 

The small brick houses inside the squares are not usually in as unsatisfactory a condition as the wooden shacks, but a large percentage of them are without adequate water supply and proper privies, and are often structurally defective.

\section{RESIDENTIAL ALLEYS SHOULD BE ELIMINATED.}

A particularly undesirable and menacing feature of the poor quarters of Washington is the inside alleys. These alleys are centers of disorder and crime and they make possible the continuance of small communities uncontrolled by ordinary police inspection and unaffected by public observation and criticism. In my opinion all inside alleys, with the exception of service alleys, should be abolished, and a definite scheme for the accomplishment of this object should be adopted. While I must record these conditions as I witnessed them, I an glad to bear testimony to the work done since the passage of the act for the condemnation of insanitary buildings. The board for the condemnation of insanitary buildings was formed under this act July 1, 1906 . Since that date 61 houses in alleys have been demolished and 73 houses on streets, while 7 have been repaired in alleys and 17 on streets. The condition of the alleys and the activity of the health officers is indicated by the fact that from July 1, 190こ, to June 30,1906 , the sanitary inspectors reported 342 alleys in filthy condition.

A law passed by the Congress in 1906 appropriated $\$ 50,000$ for the expense of condemnation proceedings in the substitution of minor streets for alleys, but a recent decision of the supreme court of the District of Columbia has interposed fresh difficulties by declaring unconstitutional the assumption of the law that the entire cost of opening small streets as substitutes for alleys should be assessed upon the adjacent property owners. I am not prepared to make any specific recommendations to meet this new difficulty, but urge that it be not allowed to prevent the abolition of inside alleys.

\section{ADDITIONAL INSPECTORS NEEDED.}

For the proper inspection of small houses, shacks, and alleys a large and efficient force of building and sanitary inspectors is necessary. Two additional inspectors will be available July 1, 1907, but these are not sufficient.

The pressure of regular work, the details of administration, and the amount of time required each session in preparing and presenting information to Congress make it extremely difficult, in my opinion, for the District Commissioners to give to the housing problem the time and serious attention which it demands.

\section{A SPECIAL COMMIISSION RECOMMENDED.}

Your message to the Congress on December 1, 1904, the experience of other communities, and the conditions which. I have reported indicate the ralue of the appointment of a special commission to consider the housing problem of the District of Columbia. Recent housing commissions in other cities have not only considered ques- 
tions of building construction and sanitation but many other matters affecting the pliysical, social, and moral welfare of the dwellers in small houses. Questions of building, construction, and sanitation are being considered by the building commission appointed by the District Commissioners, and action on these lines may be safely delayed until this commission has reported and its report has been acted upon by the District Commissioners. On the other hand there are many questions affecting the welfare of the dwellers in small houses which should receive the attention of a housing commission. Such are, among others, the need of recreation grounds and public baths, remedial agencies for the immoral life in the alleys, and agencies for social betterment, such as industrial education, the free public library, and the encouragement of the excellent system of model workingmen's dwellings, similar to those built by the Washington Sanitary Housing Company. This wide field merits attention from the broad point of view of social betterment with the home and not merely the house as the subject of fundamental interest. I therefore recommend the appointment of a commission to be known as "The President's homes commission." If this recommendation meets your approval, I would make the following suggestions regarding it :

PLANS FOR THE COMIMISSION'S WORK.

First. The President's homes commission should be composed of 15 members, to include among others a real-estate dealer, a practical builder, and two representatives of trade unions.

Second. That the commission shold be instructed to ascertain and consider the results of the best efforts of public enterprise and private philanthropy to improve the homes and better the lives of the industrial classes in other cities in the country.

Third. It should be instructed to invite the cooperation of all having interest in the housing problem and the home problem in the District, and before presenting its final report it should give public bearings on the main points of its programme so that all just criticisms may be heard.

Fourth. It should be advised to recommend, as far as possible, reforms which may be accomplished by your executive order or by the action of the District government.

Fifth. The commission should serve without compensation and all expenses incurred should be borne by voluntary contributions.

The task of preparing a satisfactory housing code, of the rearrangement of the building space within the larger squares of the District of Columbia, and of bettering the physical, moral, and social condition of the industrial classes needs the serious consideration of such a body, and its work would be productive of widereaching and permanent benefit to the District. Thus the homes of the poor might have a consistent place in the fair aspect of the nation's capital.

Respectfully submitted.

James Bronson Reynolds. 
MEETING FOR ORGANIZATION.

The first meeting of the commission was held at the residence of Gen. George M. Sternberg, 2005 Massachusetts avenue, on the evening of May 29. At this meeting there were present: Gen. George M. Sternberg, Dr. George M. Kober, Mr. P. J. Brennan, Mr. J. B. Reynolds, Mr. F. L. Siddons, Mr. William H. Baldwin, Mr. Whitefield McKinlay, Mr. Emmett L. Adams, Mr. William F. Downey.

The meeting was called to order at $8 \mathrm{p}$. m. by Mr. Reynolds as chairman pro tempore, and on motion of Doctor Kober, seconded by Mr. Siddons, General Sternberg was unanimously elected chairman of the commission. Mr. Baldwin acted as secretary for the evening.

General Sternberg read a letter from Mr. Reynolds suggestive of the work which the commission might take up, and considerable discussion, in which the different views of those present were given, followed.

Doctor Kober moved that a committee on finance, with power to collect the funds necessary to carry on the work of the commission, be appointed by the chairman, and this motion was carried.

On the motion of Mr. Reynolds, seconded by Mr. Brennan, it was decided that the commission have a committee on the erection of model houses.

On motion of Mr. Reynolds, seconded by Mr. Siddons, it was decided that the commission have a committee on improvement of existing houses and the elimination of alley and insanitary houses.

On motion of Mr. Siddons, seconded by Mr. Brennan, it was also decided to have a committee on social betterment.

$\mathrm{Mr}$. Baldwin moved that the chairman of the commission, with the chairman of each of these four committees, constitute an executive committee. This motion was seconded by Mr. Siddons and carried unanimously.

On motion of Mr. Siddons, seconded by Doctor Kober, it was decided to invite Mr. Charles F. Weller to serve the commission as temporary secretary.

On motion of Mr. Brennan, seconded by Mr. Siddons, the chairman was authorized to appoint the members of the four committees above provided for.

\section{FOUR COMMITTEES ORGANIZED.}

In a communication dated June 1, 1907, the chairman announced the following committee appointments, made in accordance with authority given at the meeting of the commission held May 29:

FINANCE COMMITTEE.

Mr. S. Wr. Woodward, chairman.

Mr. James B. Reynolds.

Mrs. Thomas T. Gaff.

Mr. F. L. Siddons.
Mr. John B. Sleman, jr.

Mr. P. J. Brennan.

Miss Mabel T. Boardman.

COMMITTEE ON BUILDING OF MODEL HOUSES.

Gen. George M. Sternberg, chairman. Ir. T. C. Parsons.

Prof. George W'. Cook.

Mr. P. J. Brennan.
Mr. Whitefield McKinlay.

Mr. John B. Sleman,

Miss Mabel T. Boardman. 
COMMITTEE ON IMPROVEMENT OF EXISTING HOUSES AND ELIMINATION OF INSANITARY AND ALLEY HOUSES.

Mr. William H. Baldwin, chairman.

Mr. F. L. Siddons.

Mr. S. W. Woodward.

Mr. T. C. Parsons.

Mr. Emmett L. Adams.

Prof. George IV. Cook.

Mr. William F. Downey.

SOCIAL BETTERMENT COMMITTEE.

Dr. George M. Kober, chairman.

Mr. James B. Reynolds.

Mr. Wiliam F. Downey.

Mr. Whitefield McKinlay.
Mr. Emmett L. Adams.

Mrs. Thomas T. Gaff.

Miss Mabel T. Boardman.

At subsequent meetings of the commission the following reports outlining the work of the commission were read and adopted after full discussion.

\section{Report of Comrmittee on Building Model Hotses.}

Under existing laws and building regulations no more houses can be built in the alleys of the city and the insanitary houses now existing on these alleys and on many of the streets must be improved or destroyed.

\section{INCREASING NEED OF SMALL HOUSES.}

A law was enacted May 1, 1906, establishing a board for the condemnation of insanitary dwellings, and up to June 30, 1907, this board had taken action upon 479 houses, of which 203 have been demolished and the rest are either repaired or are under notice for demolition or repair. It is evident that the continued activity of this board will, in time, remedy existing evils so far as the demolition or repair of existing houses unfit for occupation is concerned. But it is also evident that in our attempt to remedy these evils construction should keep pace with demolition and that in the absence of suitable houses to take the place of those condemned there will be a constant tendency to overcrowding of the houses left and to the exaction of rents out of proportion to the value of the available houses remaining. This is in the interest of greedy landlords, but adds to the heavy burden of the poor, and especially of unskilled laborers, who, in view of the high price of food products, must find it very difficult to supply their families with sufficient wholesome nutriment.

There is at the present time in Washington a genuine "house famine," so far as houses and apartments renting from $\$ S$ to $\$ 12$ per month is concerned, and day laborers who only receive from $\$ 1$ to $\$ 1.50$ per day can not afford to pay more than this.

The fact that there is a scarcity of houses of this class shows that the demand is not likely to be supplied by private enterprise. The cost of building materials and of skilled labor is so great that the problem of building houses with good ventilation, slumbing, etc., to rent at these figures and to pay 5 or 6 per cent on the investment is difficult of solution. Indeed, the only way in which it can be solved appears to be by "business philanthropy:" that is, by an organization which builds houses not as a money-making enterprise, but for the purpose of benefiting the people for whom they are built and promoting the general interests of the community. 
PUBLIC HEALTH AND MORALS REQUIRE MORE SMALL HOUSES.

The President's homes commission should be ready to cooperate with any organization or individual whose object it is to build homes for people of moderate means. The more houses we have, built as required by existing building regulations, and renting at from $\$ 8$ to $\$ 12$ per month, the better it will be for the health and morals of the poorer class of the community. Every citizen should feel a personal interest in this matter, for, aside from any philanthropic motive, the health and morals of our poor neighbors are of vital importance to us. The prevalence of tuberculosis, typhoid fever, and other infectious diseases among the poor of the city not only increases the general mortality rate to a degree which is not creditable to us, but furnishes foci of infection from which our own homes may be invaded by deadly disease germs. Sickness and crime add very materially to the burdens of the taxpayer and no one doubts that they are fostered by over-crowded and insanitary homes and by such an environment as exists in our hidden alleys and in many old and dilapidated houses fronting on the streets in certain sections of the city.

SUBURBAN HOMES FOR WORKING MEN.

The better class of wage-earners should be encouraged to purchase suburban homes, and organizations whose object it is to aid them in securing such homes should have the support of the commission, which can give substantial aid to such projects by furnishing plans, estimates of cost, and all data necessary for the information of those who contemplate the erection or purchase of a home. With rapid transit and cheap fares it may even be possible to provide suburban homes for unskilled laborers. But projects of this kind require careful consideration and considerable capital. A slum in the suburbs would be as bad as a slum in the city, and model sanitary homes can only be built where there is an ample supply of pure water and a sewer system for the removal of excreta.

Respectfully submitted.

Geo. M. Sternberg, Chairman.

Report of the Committee on Iniprovement of Existing Houses and Elimination of Insanitary and Alley Houses.

The committee met on the evening of June 22, 1907, all being present except Mr. Parsons, and after a full and satisfactory discussion adopted the following report:

\section{IMPROVEMENT OF EXISTING HOUSES.}

The divisions of work indicated by the title of this commission are apparently correlative and closely connected, and the law of May 1, 1906 , creating a board for the condemnation of insanitary buildings, and for other purposes, in the District has an important bearing on both. This law is well considered and carefully drawn and is a result of the earnest effort made for eight or nine years by those interested in improving the housing conditions of the city, in which the Associated Charities' committee on the improvement of housing conditions took a prominent part. 
The law provides for a board with power to examine any house in the District and to require that it be put into proper sanitary condition, or be demolished and removed. This is a practical way of improving existing houses and during the year since its passage the commissioners have shown their appreciation of the long-needed authority so conferred by securing attention to 479 houses, of which 53 , which otherwise would have received no attention and continued to be insanitary, have been properly repaired.

Since a man's house is his castle, and he can not be compelled to improve it unless it violates the ordinary rules of health or safety, it is not clear that much other improvement can be secured except through the work of social betterment. An adequate law against over-crowding might indirectly help.

The commission may properly cooperate with the authorities in the enforcement of the law, in securing an increase in the force of inspectors which is very much needed, and in procuring any amendments to the law which experience and investigation may suggest.

\section{ELIMINATION OF INSANITARY HOUSES.}

The alleys of Washington were probably laid out in their present unusual form in accordance with a plan which contemplated large, deep lots, perhaps 50 feet in width, all of which would be accessible in the rear from the branching alleys peculiar to this city. No houses on the alleys were ever contemplated, and if the original plan had been adhered to, and residences limited to the wide streets, no bad results would have followed. 'The pressure of population, however, and the proximity of the wide interior spaces led to the erection of houses, at first perhaps temporary, but certainly afterwards substantial in large numbers of cases, until they came to shelter a population amounting in 1905 to 19,076 in 286 alleys. The evils of having a population in such close contact, and yet so shut out and separated from the ordinary life of the streets of the city, have long been apparent, and since the original plan has been changed in this unfortunate way efforts have been made to correspondingly change the alleys by converting them into minor streets through which the life of the city, with its light and air and freedom, might flow as in other places.

\section{A SERIOUS OBSTACLE TO THE CONVERSION OF ALLEYS INTO STREETS.}

The law passed July 22, 1892, and amended on August 24, 1894, prohibited the erection of drellings in alleys less than 30 feet wide and imposed restrictions which hindered the building of any more alley houses. It also provided for the conversion of alleys into minor streets, but nothing of importance seems to have been done under this law until the committee on improvement of housing conditions took the matter up a year or more ago with a demand that the change be made in certain typical alleys. This led the commissioners to appoint a committee of District officials to advise them as to the opening of minor streets, and cases were taken up as rapidly as they could be properly handled until, up to the present time, the opening of 12 such streets has been recommended. Two of these have been confirmed by the courts and three other cases are pending in court. The 
commissioners are proceeding as rapidly as possible in the other cases, but tlre conflict with private interests led to litigation and a decision by the Supreme Court of the United States on March 11 last which declared it illegal to assess all the damages on certain property as the law provides unless it is found to be benefited to that extent. Although the commissioners are continuing to prepare and present cases they can not, under the law, approve the verdict in any case unless the benefits as assessed equal the damages and expenses.

The law therefore should be amended, and this may be done in one of several ways: First, by providing that the total cost shall be paid. from the general funds of the District; second, by providing that any excess over benefits shall be paid out of this general fund; third, by providing that the damages shall be assessed upon all property benefited without confining it to any given area. This last will probably be the best way if compatible with the decision, as it will permit the commissioners to continue the work without requiring an application to Congress in each case, or an appropriation from the general funds, as must be done if all or part of the expense is to be provided for in that way.

Under such proceedings the alley houses which remain will be changed by bringing to them a street connected with the common life of the city. Any other houses built will be likely to be better because the increased value of the land will demand it.

The commission should carefully study the situation here and also inform itself as fully as possible of what has been done to remedy any similar conditions in other cities, so that it may not only cooperate with the District Commissioners in securing such an amendment to the law as will best meet the difficulty above referred to, and in promoting the enforcement of the law in all other proper cases, but may also be able to suggest any other steps which investigation and experience indicate.

Respectfully submitted.

\section{Wrr. H. BaLdwin, Chairman.}

\section{Report of Committee on Social Betterment.}

The committee on social betterment is of the opinion that in order to suggest appropriate and effective remedies, it is essential to determine, as far as practicable, the causes which are responsible for the many deplorable conditions found in the homes of our least resourceful people.

It is generally held that the primary causes of poverty and distress are physical, mental, and moral, and while there is much reason for assuming that this is true, nothing short of a critical inquiry will reveal the exact causes, and when these and the extent to which they operate shall have been determined the way for preventive and remedial measures may be pointed out.

So, for example, there is probably a very intimate relation between the causes of diseases and disease as a cause of poverty, and it may prove of practical value to determine the prevalence of certain diseases among certain classes of the population with special reference to wage-earners. 


\section{DISTRESS AND DEPENDENCE AS RELATED TO DISEASES.}

It is beliered that a rery interesting and profitable study could be made to determine how many of the persons who annually fall rictims to tuberculosis and pneumonia are inmates of one, two, or three room tenements and otherwise exposed to insanitary environments. A similar inquiry might well be directed to typhoid fever, infantile diarrhea, and other preventable diseases, for it must be remembered that sickness, eren if the "chief breadwinner" is not incapacitated for work, is always a source of extraordinary expense, and that funerals are financial burdens which often weigh quite heavily upon the shoulders of our neglected neighbors. An earnest effort should also be made to promote the speedy convalescence of wage-earners recovering from acute diseases. It should likewise be the aim of this committee to determine the number of physically defective children and ascertain how existing medical charities may be utilized for the cure of ruptured and deformed children of the indigent classes, to prevent permanent disabilities and dependency.

Another topic well worthy of consideration is to determine more clearly the causes of alcoholism, and to what extent bad food, improperly cooked, and the cold dinner or lunch pail and other factors, such as wages, long hours, dirty work, etc.. are responsible for the growing evil and one which doubtless incapacitates many for work.

The prevalence and extent of the drug and cigarette habits and how they may be acquired will likewise suggest preventire and remedial measures. An effort should be made to determine the prevalence of venereal diseases with their evil and far-reaching consequences; indeed, the question of social and moral prophylaxis should be considered in its manifold phases, and an earnest effort made to combat vice and disease by effective educational methods.

\section{MORAL STANDARDS-RECREATION AND SOCIAL CENTERS.}

It should be the duty of this committee to learn what determines existing moral standards in poorer neighborhoods, and how they may be improved; to plan for the organization of social forces which will improve home life on its moral and social sides; to consicler open spaces, parks, playgrounds, public baths, and bathing facilities in the home and the use of schools as social centers. and the possible development of other centers for wholesome community life, and the creation of innocent amusements in connection with schools, churches, and other agencies calculated to counteract the alluring influences of saloons and evil resorts.

\section{EARNING POWER AND LIVING EXPENSES.}

To study means of saring the earning porrer nom wasted through preventable diseases, idleness, morbid and vicious habits, lack of opportunity, inefficiency, and degrading influences.

To study food and domestic economy, and ascertain the minimum expenditures now necessary to maintain efficiency. To study occupations and wages available for the working classes, public means of promoting industrial efficiency and increasing earning power. To. 
ascertain what improvements of home life are possible in view of present incomes and expenses, and to generally improve the standard of life of poorly paid wage-earners.

WAGES, THRIFT, EIPLOYIIENT, BENEFICIAL ORGANIZATIONS, SCHOOLS.

How to promote thrift and the more effective use of present earnings. Methods of enlisting and the more effective use of present earnings are found to be insufficient. To make recommendations in reference to employment agencies, life insurance, sick benefits, and loan societies.

The committee belieres that while valuable information is already a vailable much remains to be done in order to aroid erroneous conclusions.

A careful collection and critical analysis of facts should enlighten us as to the fundamental causes of poverty and distress, and when these are more accurately determined, it may be found that as in disease, so in sociological problems, preventive measures are the most effectire and economic remedies in the end.

A radical change can not be expected until the results of research and experience are made accessible to every child in the land, and it is hoped that the time is not far distant when uplifting influences will be the theme of education in every home, school, and church. The human race is now living in an intellectual and spiritual age and has a right to demand that the facts concerning the preservation and promotion of health and morals should be made a matter of public education, which should not cease in the primary schools. It is to be deplored that questions concerning the health, happiness, and eren the soul or spirit of man should have received, upon purely sentimental grounds, absolutely no attention in the public schools, and it is hoped that the work of the committee will serve to emphasize the importance that during the period of education and formation of character, greater attention must be giren to the consideration of such vital questions as have been referred to in the foregoing prospectus of the committee's work.

Respectfully submitted.

\section{George M. Kober, Chairman.}

\section{Expenses, Estimated-Contributions Needed.}

The chairman of the finance committee at a meeting held June 19 reported that he had been absent in the Orient and had just returned to the city, and that in his opinion it would be wise to postpone the collection of funds for carrying on the work of the commisison until October 1, as many of those to whom we might look for assistance were now absent from the city. After a full discussion upon the financial needs of the commisison it was decided that to fully carry out the work as outlined by the several committees an effort should be made to secure at least $\$ 10,000$.

WORI AND PROGRESS IN THE PAST-PRESENT NEEDS.

In concluding this preliminary report the commission desires to call attention to the fact that the District Commisioners, prominent members of the committees of Congress on the District of Columbia, 
and many public-spirited citizens of the city of Washington have long recognized many of the evils referred to in Mr. Reynolds's report, and that earnest efforts have been made to remedy these evils by legislation, revision of the building regulations, and the organization of companies for building sanitary homes at reasonable rentals. Much has already been accomplished in the way of securing necessary legislation for the condemnation of insanitary houses and in the construction of model houses. But to remedy the evils still existing is a task which will require the combined efforts of the District authorities, of Congress, of public spirited citizens, of philanthropists, and of the President's homes commission. It will be our aim to cooperate, so far as may be practicable, with all organizations and agencies having in view the social, moral, and physical betterment of the wageearners of the city of Washington; and especially to promote the building of sanitary homes to take the place of the insanitary and orercrowded houses now occupied by a considerable proportion of the population.

Respectfully submitted.

\section{The President's Hones Conmission.}

This preliminary report, after being submitted to President Roosevelt, is published with his permission. 


\title{
REPORT OF COMMITTEE ON BUILDING OF MODEL HOUSES.
}

\author{
By Gen. George M. Sternberg, M. D., LL. D., Chairman.
}

The President's Homes Commission, Appointed by President Theodore Ronsevelt.

Gen. George M. Steruberg, U. S. A., President.

George M. Kober, Secretary.

John B. Sleman, jr., Treasurer.

William H. Baldwin.

Frederick L. Siddons.

Prof. George W. Cook.

Whitefield McKinlay.

Miss Mabel T. Boardnan.

Mrs. Thomas T. Gaff.
James Bronson Reynolds.

S. W. Woodward.

T. C. Parsons.

Emmett L. Adams.

P. J. Brennan.

William F. Downey.

EXECUTIVE COMMITTEE.

George M. Steluberg, Chairman.

George M. Kober.

William H. Baldwin.
Frederick L. Siddons.

S. IV. Woodward.

Miss Mabel T. Boardman.

COMMITTEE ON BUILDING OF MODEL HOUSES.

George M. Sternberg, Chairman.

T. C. Parsons.

George IV. Cook.

P. J. Breunan.

COMMITTEE ON IMPROVEMENT OF EXISTING HOUSES AND ELIMINATION OF INSANITARY AND ALLEY HOUSES.

William H. Baldwin, Chairman.

S. W. Woodward.

T. C. Parsons.

George W. Cook.
Whitefield McKinlay.

John B. Sleman, jr.

Miss Mabel T. Boardman.
F. L. Siddons.

Emmett L. Adams.

William F. Downey.

SOCIAL BETTERMENT COMMITTEE.

George M. Kober, Chairman.

James B. Reynolds.

Tilliam F. Downey.

Whitefield McKinlay.

\section{COMMITTEE ON BUILDING REGULATIONS.}

Frederick L. Siddons, Chairman. William H. Baldwin. George M. Sternberg.

FINANCE COMMITTEE.

S. W. Woodward, Chairman.

James B. Reynolds.

Mrs. Thomas T. Gaff.

F. L. Siddons.
Emmett L. Adams.

Mrs. Thomas T. Gaff.

Miss Mabel T. Boardman.

John B. Sleman, jr.

P. J. Brennan.

Miss Mabel T. Boardman.

H. C. Macatee, Assistant Secretary.

Gustarus A. Weber, Statistician. 


\section{INTRODUCTION.}

The very notable reduction in mortality rates which has occurred in the principal cities in this country and in Europe during the past thirty years is without doubt largely due to the enactment and enforcement of sanitary regulations, based upon reliable information as to the causes of disease; to the purification of water supplies; to the construction of sewers, and to the improvement in housing conditions. It may be safely predicted that this reduction in mortality rates will continue until something like ideal conditions are attained. But there are many practical difficulties in the way of the attainment of such ideal conditions. It is necessary not only that sanitary officials should be informed as to the proper measures to secure the desired result, but that the public generally should be educated with reference to the causes of the preventable diseases and the best methods of combating them; and especially that legislators should appreciate the importance of sanitary legislation and should learn to give as earnest consideration to questions relating to the public health as to those concerning commerce, taxation, the administration of justice, etc.

In the present state of our knowledge it is quite possible to formulate sanitary regulations, which, if enforced, would bring about ideal conditions and reduce mortality rates to the minimum. But there are practical difficulties to contend with which to some extent, at least, appear to be insurmountable. Thus we know that epidemic influenza, or grip, is an infectious disease which causès, directly or indirectly, a considerable number of deaths, especially among the aged. But to stamp out this disease by isolation of the infected individuals appears to be quite impracticable. The same is true of tuberculosis, although the difficulties in this case are not quite so great, and segregation of the sick in hospitals and sanatoria is being carried out to an increasing extent. So, too, with reference to housing conditions. It is easy enough to enact laws requiring substantial and fireproof construction, bathrooms .with sewer connections, well-ventilated bedrooms having a given air space for each occupant, etc. But the practical question at once presents itself as to who will build such houses for the poor if they can not afford to pay rents which will yield a reasonable interest on the cost of construction.

The slums of our great cities have developed, partly because the absence of suitable building regulations has permitted the erection of cheap structures with small, dark rooms, inadequate toilet facilities, etc., and partly by the decadence of localities where the houses were originally good enough, but where dilapidation and decay have necessitated a lowering of rents and have brought them within the reach of the poor, on condition that overcrowding to the limit possible is permitted. It is evident that when, in a growing city, building regulations are enacted which prevent the profitable investment of capital in houses for the laboring classes a house famine is bound to occur, and there will be a constant tendency to overcrowd the old houses a vailable for occupancy. Regulations to limit this overcrowding will be difficult to enforce, for shelter of some kind is a prime necessity for everyone. And in a growing city a considerable proportion of the population must consist of unskilled laborers, whose ability to pay for shelter is limited strictly by the amount of wages they receive. It is commonly, and we think justly, estimated that a workman should not be 
obliged to pay more than one-fifth of his income for rent. For the clerk and the mechanic whose pay is better and who works but eight hours a day it is quite practicable to establish a home in the suburbs. where land is cheap and a frame cottage can be built at a comparatively small cost. But cities need many unskilled laborers to work upon the streets and upon buildings under construction, as porters, drivers, etc., and these laborers need shelter as near their place of work as is practicable. It is the business of the municipality to see that the houses in which these laborers live are sanitary in their construction and in their surroundings, and that they are not orercrowded; but whose business is it to build such houses, and who will do it unless it can be shown to be a safe and reasonably profitable investment? In some European countries, and especially in England, an attempt has been made to solve this problem by governmental action, general or municipal, and in many instances there has been cooperation between the municipality and private corporations. Space will not permit me to give a review of the extensive housing enterprises which have been carried out in Europe and on the Continent, but the English method of financing such enterprises is worthy of special attention. I quote from "Housing-Up-to-Date" (1907), by W. Thompson, author of the "Housing Handbook."

The public works loan commissioners.-This body gets its funds from the national debt commissioners, supplemented by the proceeds of local loan stock, $£ 20,000,000$ of which has been borrowed from the sarings bank, which gives $2 \frac{1}{2}$ per cent to its depositors.

The commissioners are supposed to assist minor housing authorities with loans, and also housing companies and societies, as well as individuals willing to erect dwellings for the working classes. The total amount advanced for housing purposes up to March 31,1906 , is $£ 3,938,604$, viz, $£ 2,318,765$ to local authorities on the security of local rates and $£ 1,619,929$ to companies and private persons on the security of property.

The period for repayment is limited as follows: Local authorities, England and Wales, fifty years; companies and private persons, England and Wales, forty sears; local authorities, Scotland, thirty years.

The rates of interest are fixed by treasury minute from time to time. From April, 1904, to September, 1907, they were as follows for local authorities:

Loan period not exceeding twenty years, $3 \frac{1}{2}$ per cent per annum.

Loan period not exceeding thirty years, 33 per cent per annum.

Loan period not exceeding forty years, 4 per cent per annum.

Loan period not exceeding fifty years, $4 \frac{1}{4}$ per cent per annum.

On September 13. 1907, a treasury minute reduced these rates to $3 \frac{1}{2}$ per cent for thirty years and $3 \frac{3}{4}$ per cent for fifty years. The fees payable to the board vary from $£ 1010 \mathrm{~s}$. for a loan of $£ 1,000$, and $£ 22$ s. for a loan of $£ 3,000$ to $£ 31$ for a loan of $\{10,000$, in addition to fees for services by the office of works and for out-of-pocket expenses. The mean rate of interest for the last thirty-two

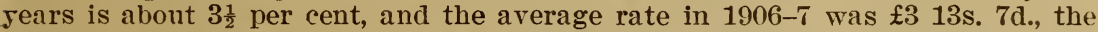
highest rate for twenty-one years. The amount advanced has averaged about $£ 2,637,322$ per annum, and the amount now outstanding is $£ 49,636,955$, of which

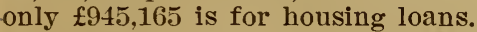

Housing loans to societies of public utility and to individuals.-In lending money for housing purposes under section 67 of the act of 1890 it has been the practice of the public works loans commissioners to discriminate between those borrowers who will agree to restrict the dividends to not more than 5 per cent and those not so agreeing.

The treasury minute of 1904 provides for lending to the companies and indiriduals who will agree to restrict their dividends to not more than 5 per cent at the same rate of interest as that charged to local authorities.

The London County council up to March 31, 1906, had provided accommodation for $.33,853$ persons, calculated on the basis of two persons to a room, in 6,326 dwellings of one to six rooms each, and 1,147 cubicles in lodging houses. The cost of buildings and the housing valuation of the land amounted to about

S. Doc. $599,60-2-3$ 
$\pm 1,900,000$, and the gross rental value of the dwellings completed and opened was approximately $\mathfrak{f} 136,000$ per annum, or 7 per cent on the estimated outlas, the net rental being $£ 121,5 S 3$, and working expenses and interest, $£ 101,690$, leaving $£ 11,106$ for sinking fund, $£ 5,411$ for repairs, renewals, and reserve, and $£ 3,346$ net surplus.

In addition to the schemes carried out under the housing acts, the council has provided dwellings capable of rehousing 11,198 persons, in place of dwellings of 10,988 persons displaced in connection with the construction of tunnels, the widening of streets, and other public works.

In Germany large sums have been lent by the Imperial Government and by several of the States to corporations organized for the purpose of building houses for the working classes. In France savings banks, hospitals, and benevolent institutions are authorized by law to invest their funds in similar corporations, and the State exempts such companies from paying two of the heaviest taxes, namely, that of ground rent and that on doors and windows, the exemption to be for a period of twelve years. To profit by this exemption the highest rent of such buildings must not exceed $\$ 110$, or if these dwellings be in the form of separate houses, $\$ 132$. In America the problem of building sanitary homes for the laboring classes has been left entirely to philanthropy and private enterprise.

Mr. Thompson, in his Housing Handbook, says of private enterprise:

It has been assumed by thousands who ought to have known better that private enterprise, unstimulated, unregulated, unassisted, undirected, has hopelessly failed. It has left us face to face with a very deficient supply; it has given us the old slums; it has giren us only often acres and acres of new slums in the suburbs, jerry-built "brick boxes with slate lids" dumped down on dust heaps and put up mainly with the object of getting a quick profit in the few rears which will elapse before they degenerate into slum dwellings almost as bad as the old ones in our midst. Where the new houses are well built and on good sites they are of an unsuitable tyle, and the rents are so unreasonably high as to be beyond the means of one iamily, so they have to be sublet to other families, and thus by orercrowding, with the increased wear and tear following in its train, they rapidly deteriorate and leare the housing of the mass of the people as bad in many respects as it was before. The product of private enterprise then is insufficient in quantity and inferior in quality.

These remarks are no doubt applicable, to some extent at least, to the results of private enterprise in our own cities, except in those cases where men of means have built model houses from philanthropic motives, rather than as an investment.

It is hardly necessary to insist upon the importance of supplying the laboring classes of a city with sanitary homes at reasonable rentals. A house famine and excessive rentals must infallibly result in overcrowding, with all the evil consequences to the health and morals of the occupants which attend such overcrowding. Upon. this subject I desire again to quote from the Housing Handbook:

Taking England and Wales as a whole, the census of 1891 shorred three and one-fourth million people living in overcrowded dwellings, while 660,000 people had only one room to live in. Unfortunately, the census returus in England do not give the total number of rooms a vailable in working-class dwellings; but in Scotland we see by the census of 1901 that there were only $3,022,077$ rooms for 969,318 families, including all classes, or an average of three rooms to each family, the total population thus housed being 4,4i2,000. In 189150 per cent of these were "overcrowded" on the basis of the census definition.

Two-thirds of the present population of London hare houses containing not more than four rooms, and these in most cases without adequate sanitary conreniences, open spaces, sunlight, and air. In 1891 about 900,000 people (equal to the entire population at the beginning of the nineteenth century) were living 
in orercrowded rooms. At least 386,000 had to sleep, wash, dress, cook, eat, live, and die in that abomination, the "one-room dwelling."

In Glasgow, the second city of the Empire, and the modern municipality, things are worse. Not less than one-fifth of the people live in one-room dwellings; more than half the people have houses with not more than two rooms; 87 per cent have three rooms and less, while 90 per cent of the new houses built during the last three years have not more than three rooms.

In Edinburgh, the modern Athens, more than half the homes consist of one and two rooms, while in some districts, such as the Canongate and South Giles, this proportion is as high as 70 per cent.

This enormous amount of overcrowding not only enables high rents to be obtained, but by increased wear and tear of the houses, by the strain it imposes on inadequate sanitary appliances and resources, by the dirty and insanitary habits it engenders, quickly drags down even those houses which in themselves are structurally sanitary when not orercrowded, and thus creates new slums faster than the old ones can be improved, besides establishing among numbers of young people a low standard of home life and sanitation which years of education will be required to eradicate.

Not only the United Kingdom, but in most of the great cities of the world, the people are overcrowded on areas as well as in rooms. This arises in two ways. In the first place, especially in England, an inadequate amount of open ground space is left round each building; and, in the second place, by means of piling up rooms several stories high light is obstructed and the air is polluted much more quickly than it can be removed or purified. The latter system prevails more in Glasgow and in continental cities than it does in London, and this partly explains why Paris, with only 44 per cent of its population orercrowded in rooms, has a higher death rate than London, with 20 per cent overcrowded. It is a rery significant fact that in spite of strict supervision, careful structural sanitary arrangements, and a picked population, the death rate in model block dwellings in London is often as much as 30 per cent higher than the average of all classes of dwellings in the adjoining county of Surrey, while deaths from phthisis, scarlet ferer, and diphtheria have been often higher in these model blocks than the arerage of London-slums and overcrowded rooms and old houses included.

It is a well-established fact that infant mortality is very much greater in overcrowded houses. Mr. Thompson says: "Infant mortality varies almost arithmetically with housing conditions. Although children under 5 years are only one-ninth of the population, they furnish one-third of the deaths.'

That the death rate in cities is largely influenced by the number of occupants to a room has been repeatedly demonstrated by sanitary statistics. Mr. Russell in his statistics of Glasgow (187i to 1880) found that the general mortality was 21.7 per thousand, when the average occupancy per room was 1.31 ; when the average was 2.05 for each bedroom the mortality increased to 26.6 per thousand. It can readily be understood that the closer people are crowded together the greater will be the liability for the transmission of infectious diseases, such as diphtheria, scarlet fever, tuberculosis, etc. And when they live in an atmosphere which is vitiated by the emanations from the lungs and bodies of human beings, with insufficient rentilation and a deficient supply of sunlight - nature's great disinfecting agent-their susceptibility to infection is greatly increased. In his investigations made in Budapest, Korosi found that the mortality from infectious diseases was 20 per thousand when there were only two occupants per room; where the number was from three to fire the mortality was 29 per thousand, and where it was from six to ten the mortality increased to 32 per thousand.

In the city of Washington the death rate among the colored population in 1875 was 42.86 per thousand. In 1906 it had fallen to 28.81 per thousand. Among the whites it was 21.04 in 1875 , and in 1906 it 
had fallen to 15.16. To what extent this decline in the death rate is due to improvement in housing conditions it is impossible to say, but no doubt there has been some improvement, and this is one of the factors which accounts for the gradual reduction of our death rate from the disgracefully high figures of twenty-five or thirty years ago.

We can not do better than to quote here the forceful language of President Roosevelt in his message to Congress in December, 1904:

In pursuing the set plan to make the city of Washington an example to other American municipalities, several points should be kept in mind by the legislators. In the first place, the people of this country should clearly understand that no amount of industrial prosperity, and, above all, no leadership in international industrial competition, can in any way atone for the sapping of the vitality of those who are usually spoken of as the working classes. The farmers, the mechanics, the skilled and unskilled laborers, the small shopkeepers, make up the bulk of the population of any country; and upou their well-being, generation after generation, the well-being of the country and the race depends. Rapid development in wealth and industrial leadership is a good thing, but only if it goes hand in hand with improvement and not deterioration, physicial and moral. The overcrowding of cities and the draining of country districts are unhealthy and even dangerous symptoms in our modern life.

We should not permit overcrowding in cities. In certain European cities it is provided by law that the population of towns shall not be allowed to exceed a very limited density for a given area, so that the increase in density must be continually pushed back into a broad zone around the center of the town, this zone having great arenues or parks within it. The death-rate statistics show a terrible increase in mortality, and especially in infant mortality, in overcrowded tenements. The poorest families in tenement houses live in one room, and it appears that in these one-room tenements the average death rate for a number of given cities at home and abroad is about twice what it is in a two-room tenement, four times what it is in a three-room tenement, and eight times what it is in a tenement consisting of four rooms or over. These figures vary somewhat for different cities, but they approximate in each city those given above; and in all cases the increase of mortality, and especially of infant mortality, with the decrease in the number of rooms used by the family and with the consequent overcrowding is startling. The slum exacts a heavy total of death from those who dwell therein; and this is the case not merely in the great crowded slums of high buildings in New York and Chicago, but in the alley slums of Washington. In Washington people can not afford to ignore the harm that this causes. No Christian and civilized community can afford to show a happy-golucky lack of concern for the youth of to-day; for, if so, the community will have to pay a terrible penalty of financial burden and social degradation in the to-morrow.

* * $*$ * *

Several considerations suggest the need of a systematic investigation into and improvement of housing conditions in Washington. The hidden residential alleys are breeding grounds of vice and disease, and should be opened into minor streets. For a number of years influential citizens have joined with the District Conmmissioners in the rain endeavor to secure law's permitting the condemnation of insanitary dwellings. The local death rates, especially from preventable diseases, are so unduly high as to suggest that the exceptional wholesomeness of Washington's better sections is offset by bad conditions in her poorer neighborhoods. A special commission on housing and health conditions in the national capital would not only bring about the reformation of existing evils, but would also formulate an appropriate building code to protect the city from mammoth brick tenements and other evils which threaten to develop here as the have in other cities. That the nation's capital should be made a model for other municipalities is an ideal which appeals to all patriotic citizens everywhere, and such a special commission might map out and organize the city's future derelopment in lines of civic social service, just as Major I'Enfant and the recent park commission planned the arrangement of her streets and parks.

\section{HOUSING CONDITIONS IN WASHINGTON.}

The national capital was evidently intended to be a city of homes. The original lots are of generous dimensions and front upon broad 
streets and avenues. These lots provided ample room for separate houses, with space for yards in the front and rear, and the squares were laid out in such a manner as to give access, by alleys, to the rear of each lot. This plan probably had in view the location of stables on the alleys, in rear of each house. As the city grew the original lots were subdivided, and as land became more valuable a majority of the residences were built in blocks, with party walls, instead of being detached villas with light on all sides. Naturally, in the portions of the city deroted to business, this was the usual method of building from the outset, and these dwellings and stores were, as a rule, brought to the very front of the lot, thus leaving a considerable space in the rear, as the original lots were generally from 100 to 200 feet in depth. The owners of property, as land values increased, sometimes sold off the rear portions of their lots, and sometimes built small houses, facing the alleys, which they were able to let at rentals which gave them a high rate of interest on their money. These houses were often cheap frame structures, which paid for themselves within a few years. In other cases they were of brick. As a general rule, the rooms were small, and the first floor was on a lerel with the ground, without any ventilation under it. As a result of this, the sills soon became rotten, and dampness from the ground came through the floors. As a rule, also, there was no water in the house and no sewer connections. Water was often obtained by all of the residents of an alley from a single hydrant at the corner, and box privies were in general use. Many cheap frame and brick houses Trere also built upon the streets and arenues of the city prior to the adoption of proper building regulations, and these exist to-day, in a more or less dilapidated condition, often in proximity to handsome new dwellings. Many of these old houses are on valuable ground, and they serve to pay taxes until such time as the owner can sell his ground at a figure which he considers satisfactory.

The erection of dwellings in the alleys of the city was arrested in July, 1892 , by a law prohibiting the building of houses in alleys less than 30 feet wide and not supplied with sewers and water mains. Under the provisions of this law it became necessary to transform the alleys into minor streets before a permit could be obtained to build upon them. The wording of the law is as follows: "That no dwelling house hereafter erected or placed in any alley shall in any case be located less than 20 feet back, clear of the center line of such alley, so as to give at least a 30-foot roadway and 5 feet on each side of such roadway for a walk or footway, and that it shall be unlawful to erect or place a dwelling house on or along any alley which does not run straight to, and open at right angles upon, one of the public streets bordering the square in which such alley is located, with at least one exit 15 feet in the clear." Unfortunately, in Washington, as in many other cities, regulations designed to prevent the erection of insanitary dwellings were not enacted until the city had reached considerable proportions and the neglect had already given rise to conditions discreditable to the city and injurious to the sanitary interests of its inhabitants. Not only the dilapidated alley houses, but many of the old frame houses on streets and avenues are to-day crowded to a very undesirable extent, owing to the fact that the construction of houses which can be rented to the poorer 
classes of our citizens-unskilled laborers-has been practically arrested by existing building regulations. This matter will be considered more fully in a subsequent chapter of this report.

Fortunately for the national capital, we have an ample area upon which to build, and the extension of street railways in all directions makes it unnecessary to build tenement houses of three or more stories for the housing of the poor. The acute stage of overcrowding in this city was probably reached during and immediately after the civil war. It is estimated that from 30,000 to 40,000 negroes from neighboring States came to this city at that time. These unfortunate and ignorant people were obliged to avail themselves of any kind of shelter they could find. In many cases rough board shacks with leaky roofs were occupied for years by growing families, and rents were paid out of all proportion to the value of the property or the means of the tenant. Industrious colored men, whose labor would only command from $\$ 1$ to $\$ 1.50$ a day, and hard-working colored women, whose lives have been spent over a washtub, have been obliged to pay year after year, for shelter of the most indifferent kind, an amount which has yielded the landlord 20 per cent or more on his investment.

The following extracts from the report of the health officer will show the conditions existing ten years after the civil war:

Leaky roofs, broken and filthy ceilings, dilapidated floors, overcrowded, below grade, having stagnant water underneath, no drainage, no pure water supply, no fire protection, having filthy yards, dilapidated, filthy privy and leaky privy box, in bad sanitary condition generally and unfit for human habitation, described, with few exceptions, the conditions of these hovels where the poorest class of our population stay out their miserable existence, and for which ther pay rents varying from $\$ 2.50$ to $\$ 10$ per montl.

In the report of the health officer for 1875 it was noted that during the year 699 houses were reported as unfit for human habitation and 198 condemned by the board. In 1876,424 houses were reported and 371 condemned, and in the report of the board of health for 1877 , page 46 , we find:

No meaner cabins for temporary or permanent shelter can be found than some our wretched poor are born and exist and die in here at the capital of the United States. And, strange as it may seem, none so mean that they have not an owner mean enough to charge rent for them. Down in the alleys, below grade, with combination roof of tar, felt, shingles, rags, tin, gravel, boards, and holes; floors damp and broken; walls begrimed by smoke and age; so domiciled are families with all the dignity of tenants having rent to pay. The board has condemned 153 such during the past year and 958 during the past four years, of which probably 300 have been entirely demolished. But many owners still cling to the wrecks.

Our experience in dealing with filth, crowd poison, and disease among these people during the past four years has taught us that the greatest public economy, viz, the preservation of public health, is defeated by allowing these filthy, worthless, dependent classes of humanity to congregate in the alleys and byways out of sight, and, therefore, out of mind, until direful epidemic, incubated and nourished among them, spreads its black wings over the homes of the whole city. Better far to provide for the aged and sick in public institutions of charity, the vagrant in the chain gangs, let the cost be what it may, than to allow them to remain, propagators of public disease, an incalculable expense to the District.

As specific examples of overcrowding at a later date, I quote from the report of Miss De Graffenried, published in 1896:

One conclusion at least is evident, that rents in these alleys are dear, considering the accommodations and envilonment. Moreover, the moral conse- 
quences of such narrow quarters are often disastrous. Crowded sleeping rooms contribute to vice and indecency. Indeed, crowding goes on to an extent not acknowledged to the can vasser by the tenants. At night these poor roofs shelter manx more people than are here reported.

I have no doubt that lodger's are harbored in these allers whose presence, for many reasons not creditable to the occupants, is always concealer. The confessed facts are startling enough. We have here accounts of seven persons living in two rooms-the mother and her sons 21, 17, and $\tau$ years of age, occupying one bedchamber. Again, nine individuals live in two rooms; eleven people in four rooms. Fire, almost all adults, sleep in one room-the mother 43 , a son 21, and daughter's 19,17 , and 14; and four persons use another rooma mother 45 , an aunt 70 , a son 22 , and a baby 9 months old.

In the Preliminary Report of the President's Homes Commission will be found the report of Mr. James Bronson Reynolds, made to the President, and which served as the basis of his action in organizing this commission. In this report Mr. Reynolds says:

I found nearly all the alley wooden shacks and small brick houses that I visited in a wretched condition. The wooden shacks, as a rule, might properly be condemned on structural grounds. Their yards are apparently storage places for refuse aud filth, their water supply inadequate and badly placed, and the privies frequently only open boxes and in many instances without covers, although the latter are required by the health ordinance. I am glad to state that during the past year many of these box privies hare been removed.

I had a conversation with the dwellers in these inside shacks, and the comments of many may be fairly summarized in the pathetic remark of an old colored womin, who exclaimed with reference to her neglected, filthy yard and privy, " Why, my old marsa wouldn't ha' kep' his horses stabled in such a place."

No argument is needed to show that such ill-conditioned hovels are culture beds of disease, the germs of which may be carried far and wide by the flies which feed on the rotting garbage and excreta. Their number should be properly ascertained and immediate steps taken for their complete elimination, and buildings constructed in their places should have proper sanitary appurtenances and should open either upon a highway or small street.

In a few instances the dwellers in these shacks would probably merit temporary help in securing better quarters if the shacks were destroyed; but if the abolition of the shacks should result in driving their tenants from the city, in most instances an undesirable element of its population, which is at present an expense to the city through its police courts and prisons, would be removed.

The small brick houses inside the squares are not usually in as satisfactory a condition as the wooden shacks, but a large percentage of them are withont adequate water supply and proper privies, and are often structurally defective.

Of housing conditions in the suburbs, Dr. H. C. Macatee reports as follows:

In risiting suburban communities and recently opened subdivisions for the inspection of frame dwellings erected in the past five years opportunity was had at the same time to make general observations upon the character of dwellings which obtained prior to 1903 and to note how the laboring man fares outside the city limits.

So diverse are conditions in the various suburban communities that it is difficult to summarize the results of investigations. It may be said at once, howerer, that two causes underlie suburban building-real estate enterprise seeking to convert agricultural land into more remunerative building sites and the independent spirit of thrifty people seeking home ownership and healthful surroundings for their children. ${ }^{a}$ There is in it no morement to supply the demand for good homes for the overcrowded, badly housed class.

In those sections of the suburbs of comparatively recent development there are no homes for laboring men's families. There may be seen here and there a shack, about as ill conditioned as those to be seen within the city, a relic of the agricultural days of the vicinity, where the farm laborers dwelt. There are.

${ }^{a}$ For the purposes of the present study, suburban growth as a result of the building of summer homes for the well-to-do may be disregarded. 
however, sereral communities, apparently long in existence, where a considerable number of the laboring class live. In Harlem, a rillage lying along the Conluit road, between the limits of Georgetown and the distributing reservoir, there are a good many small frame houses, containing fire rooms, having both front and back porches, and surrounded by a yard. These houses are heated by stores and have no water nor gas supply. Box privies and outhouses abound. They are occupied by white tenants, many of whom own their homes. The building of such dwellings appears to have nearly ceased. This was the only community where white laborers were found, except in a row of old frame dwellings at Fort Reno.

Iry City is a negro village situated near the railroad tracks back of Kendall Green, far from any car line, and reminds one of "Mrs. Wiggs' Cabbage Patch." IVhen the city reaches out and surrounds this settlement there will be a new slum district to contend with. New dwellings are occasionally erected here by the colored people themselves, but there is no active building going on. The dwellings here do not differ much from those described as existing within the city; thes have more ground around them, however, and the structural deficiencies are somewhat compensated by the unaroidable sunlight and fresh air.

Deanwood, East Deanwood, and Burrville are scattered villages, merging into each other, and situated along the Chesapeake Beach Railway; here dwell colored people almost entirels. The villages are for the most part coniposed of new and respectable cottages owned by their occupants. Here and there may be seen dilapidated shacks occupied, while alongside stands a new cottage empty and for rent.

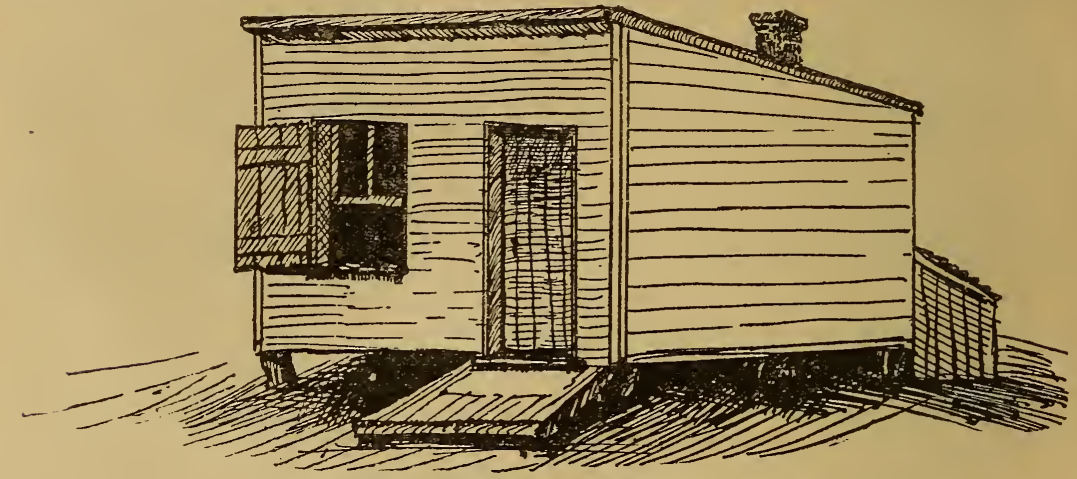

FIG. 1.-Shack in Barry Farm; one room, 10 by 15 feet; rent, $\$ 5$.

Barry farm is situated on the outskirts of Anacostia. This is another negro settlement, and is a curious mixture of comfortable cottages-eren handsome homes owned by well-to-do colored people-and tumble-down hovels that bring exorbitant rents.

Garfield and Good Hope are also colored communities on the order of Barry farm. These villages are situated on the hills to the east of Anacostia. The majority of the houses here are owned by their occupants. There are no public service advantages in these outlying regions, with the exception of public-water supply in Iry City; but even here the people do not have water within their houses, nearly always obtaining it from the street hydrant.

The communities just described are the only considerable aggregations of people of the laboring class to be found without the city limits. The character of old dwellings located in them is little better than we would condemn within the city. Nothing is being done to improve the quality of dwellings, and the new dwellings are of the cheapest kind. Moreorer, the people who live in these suburban places are not the pick and shovel men, the cart drivers, the hod carriers, the stable men of the city. They are for the most part more independent folk, such as messengers and skilled laborers in the departments ; colored men who work from place to place as porters, waiters, or house servants, and who keep their wives and children in these little homes. They are the kind who will not rest until they own "a little place in the country." It matters little what sort of dwelling may be upon the "place." The worst hovels are occupied by driftwood; widows who subsist by doing laundry work for the neighbors in 



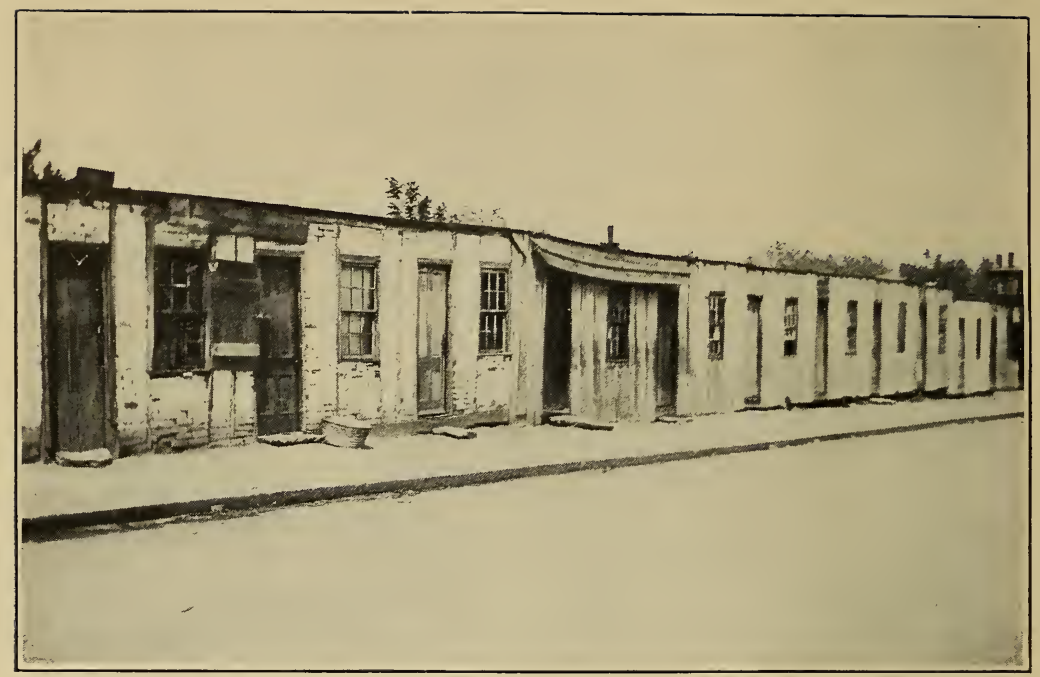

FIG. 3-SHACKS ON VAN STREET SOUTHWEST.

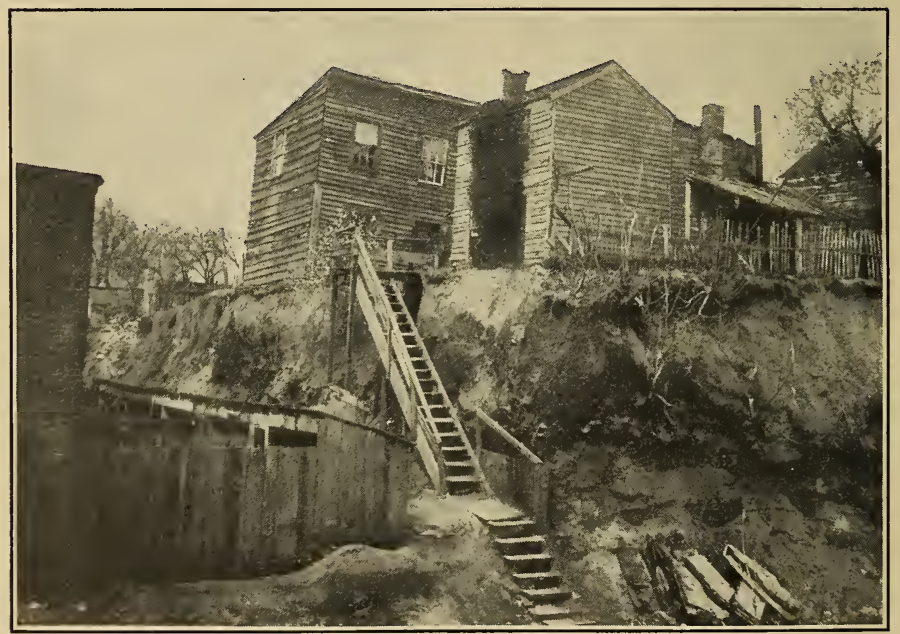

FIG. 4.-VIEW OF INSANITARY SHACKS WITH BOX AND BARREL PRIVIES, SIX SQUARES FROM DUPONT CIRCLE 
better circumstances, old people supported by sons and daughters in the city, and the children of the sons and daughters.

It appears that suburban dwellings are rery sellom built with the intention of renting them. Suburban houses as a rule are built for sale; are built by the promoters of a subdivision for the purchaser of a lot, payments made monthls, or are built by lot owners, the money obtained from building associations frequently. The inquiry, "Do you own your house or rent it?" very frequently elicited the answer, " Well, we're trying to own it." Unfortunately, if the information had is reliable, in some of the colored communities, notably such as East Deanwood, Burrville, and Garfield, "trying to own a home" frequently meets with failure. House and lot, it is said, may change hands three or four times, in default of installments of purchase money, before title is secured by the purchaser. Thus the profit of the real-estate promoter or of the building association is augmented several times before, the property is finally relinquished.

The total impression gained by the survey was that there is as little, or less, benerolence in the suburban real-estate business as elsewhere; that the laboring man has nothing to gain by seeking a residence outside the city limits, and that only grim determination will succeed in securing a home by mechanics, clerks, and the like with a better and more certain income.

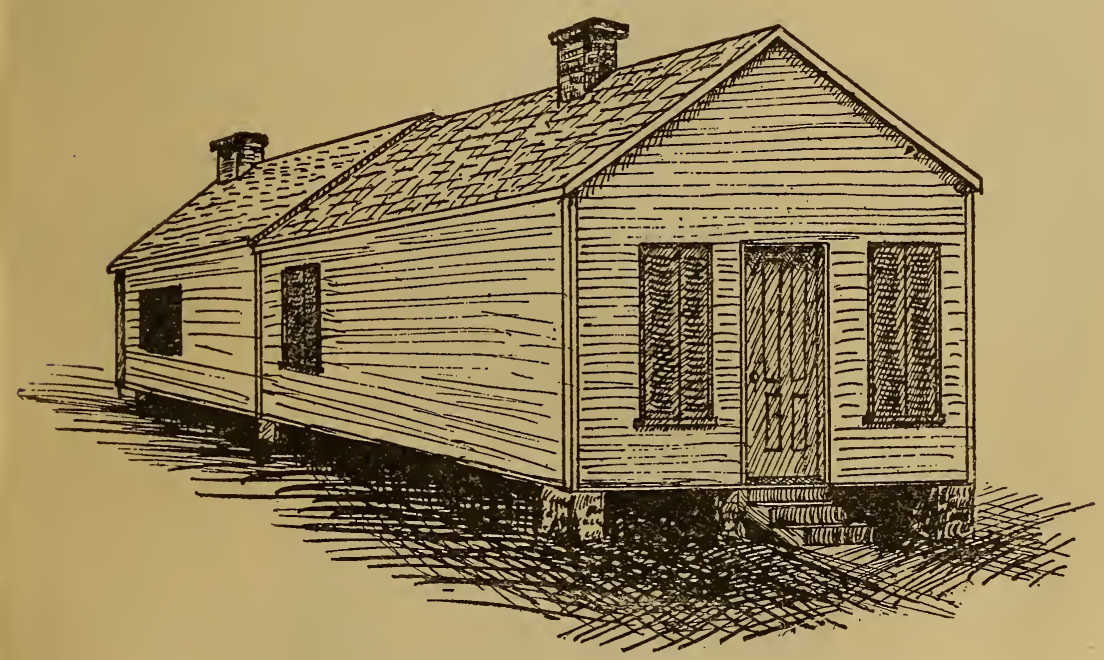

FIG. 2.-Garfield, D. C. ; three rooms ; rent, $\$ 8$.

\section{TYPES OF WASHINGTON HOUSES OCCUPIED BY THE LABORING CLASSES.}

The shacks shown in figure 3 were erected during the civil war as temporary barracks for soldiers, and have been occupied since by colored people of the lowest class until the year 1905, when they were demolished, after the erection of a row of two-story brick houses on the opposite side of the street by the Washington Sanitary Housing Company. There are many other frame structures in the alleys of the city, and even facing upon the streets, which are little if any better than these shacks. While such apologies for shelter are to a great extent occupied by idle and dissolute colored people, some of the tenants, although ignorant and low in the scale of intelligence, are honest and hard-working. Day laborers may go from such hovels to their long day of toil, returning to them for shelter and the necessary sleep which kind nature bestows upon the tired brute, but often refuses to the pampered child of wealth and fashion. Laundresses bring to such 
places baskets of soiled clothes from the houses of the well-to-do and return them to the owners apparently clean, but possibly soiled with the germs of some infectious disease. Children grow up in such shacks, and a certain proportion of the girls no doubt go into domestic service and learn something of civilized methods of living. But the tendency of such surroundings is of course in the direction of vice and immorality.

Figure 4 illustrates another type of which there are numerous examples. Frame houses originally on the outskirts of the city, dilapidated by age and, sometimes, as in figure 4, left far above the street level, often furnish shelter for several families and swarm with children.

Again we have rows of cheap brick or frame dwellings, built on speculation prior to the enactment of suitable building regulations. These have a narrow frontage (12 to 14 feet); they usually have no ventilation under the ground floor, which is not infrequently below the street level; the rooms are small; a narrow, dark stairway leads to the upstairs bedrooms; the roofs are often leaky and the plastering falling; a lean-to kitchen in the rear, 8 or 9 feet square, often counts as a room, and in some cases there are cellar-like basement rooms, which may be occupied as bedrooms.

For the better class of wage-earners, who are able to pay from $\$ 15$ to $\$ 20$ monthly rent, there are of course better houses and, as is shown in Section VI, their needs are being met to some extent by new buildings, constructed with due regard to sanitary requirements. For the man who can pay from $\$ 20$ to $\$ 30$ a month for, a house or apartment there is a reasonable supply, and the demand is likely to be met by private enterprise. But for those who can not afford to pay as much as $\$ 12$ to $\$ 15$ the only resource is to occupy an alley house, or one of the old frame houses, such as are shown in figure 7 , or one of the cheap brick houses built prior to the enactment of proper building regulations. And, even then, he will usually be compelled to sublet one or more rooms in order to meet his rent.

It is no uncommon thing to find that the rent is paid by an industrious colored woman, who spends her days at the washtub (see fig. 8), and also manages in some way to provide food and clothing for several children. Sometimes she is the sole support of her family, because she is a widow or deserted wife, and sometimes because she has an idle and worthless husband.

A new type of houses was introduced in the city of Washington in 1897 by the Washington Sanitary Improvement Company, an organization having for its object the construction of sanitary homes for working men at reasonable rentals. This is the two-flat type. Each house is of two stories, and each floor consists of an independent flat of three, four, or five rooms. Each flat has a separate entrance from the street, a back yard, a small cellar, and an exit to the alley in the rear. That is, there are two independent homes under one roof, which have nothing in common. The plan, which was devised by the present writer, was intended to eliminate all the unpleasant features of tenement houses as they exist in other cities. A good range, with waterback, is placed in the kitchen, and each flat has a well-lighted bathroom, with hot and cold water. The following photographs and drawings will serve to illustrate this type, which has proved very popular. 


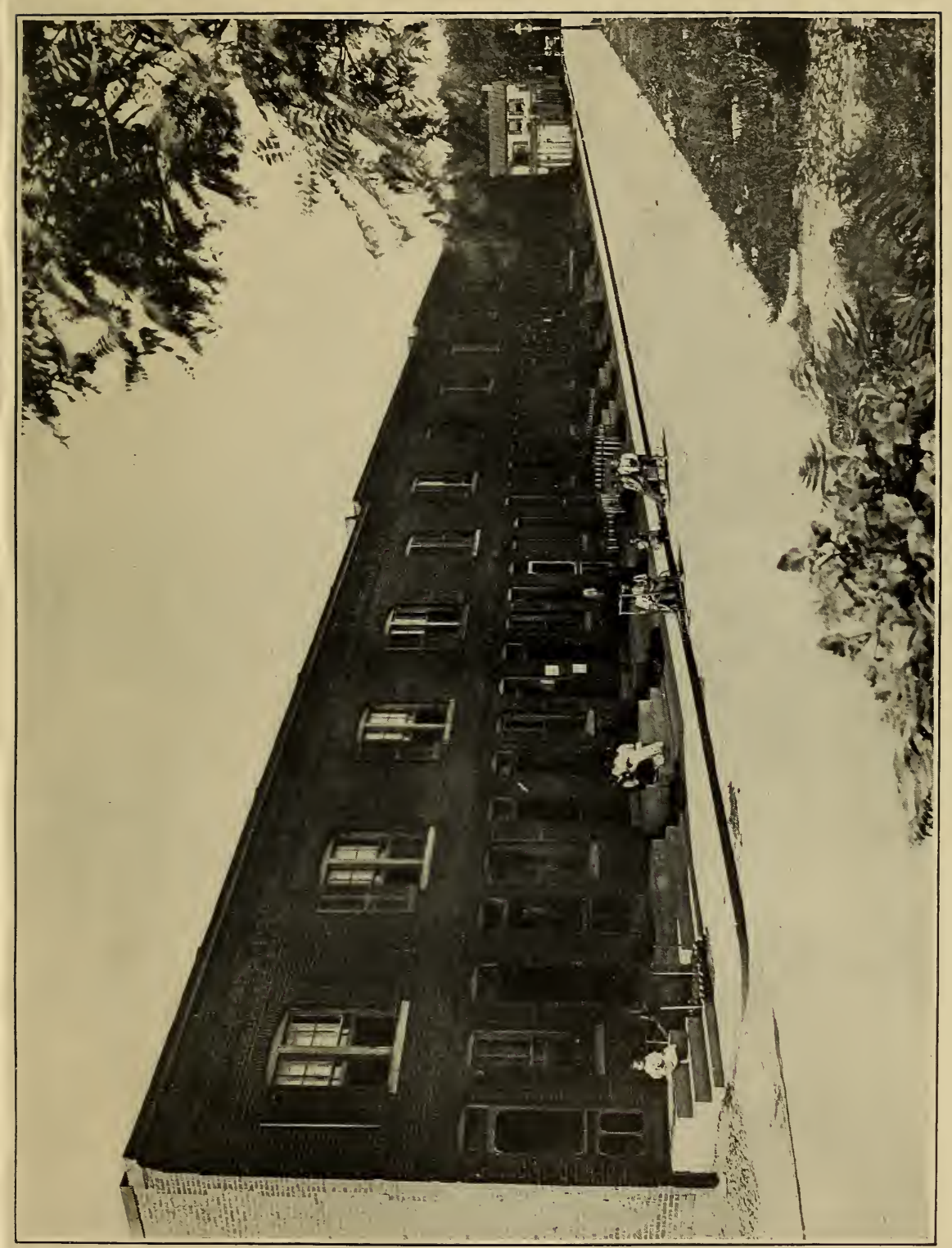

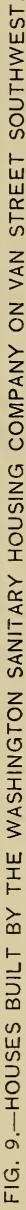




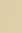




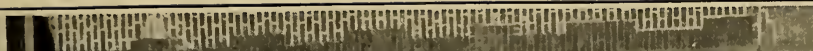
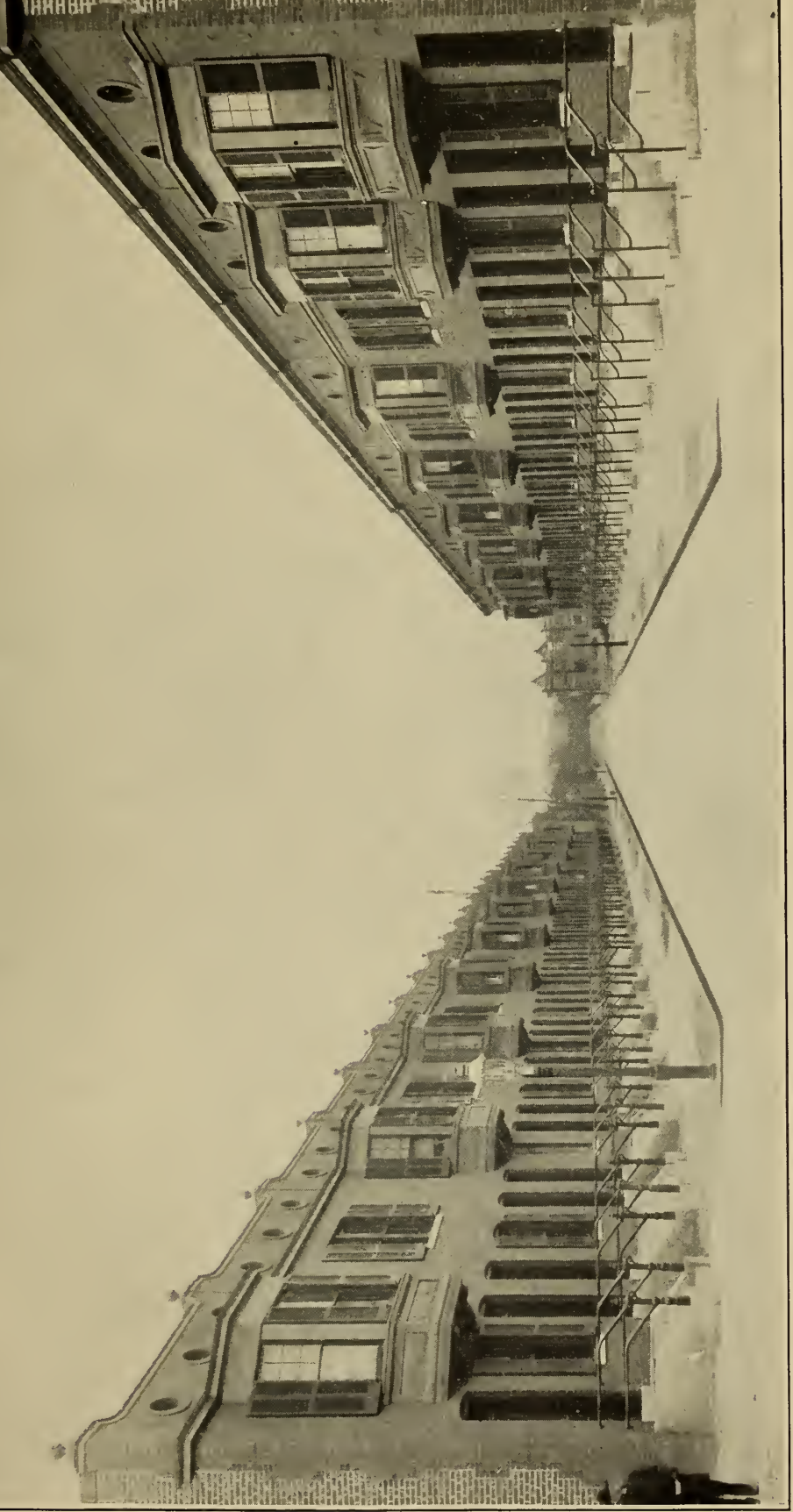

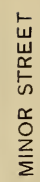

$\stackrel{ }{-}$

岂

占

崩

它

แ

苑

1

음

ज़ 



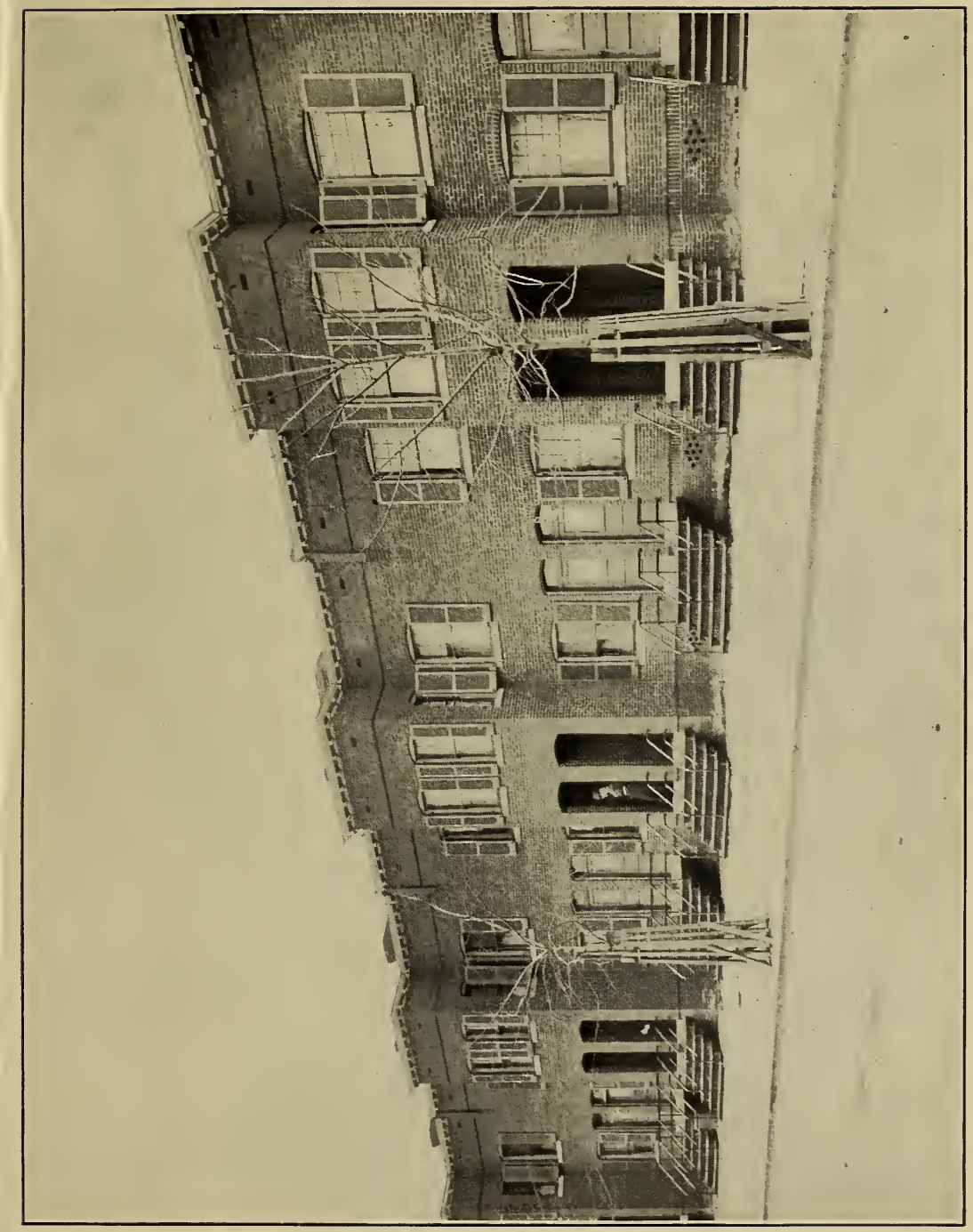

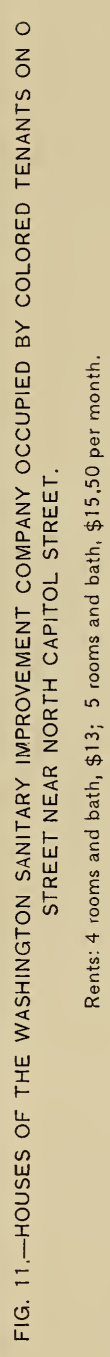





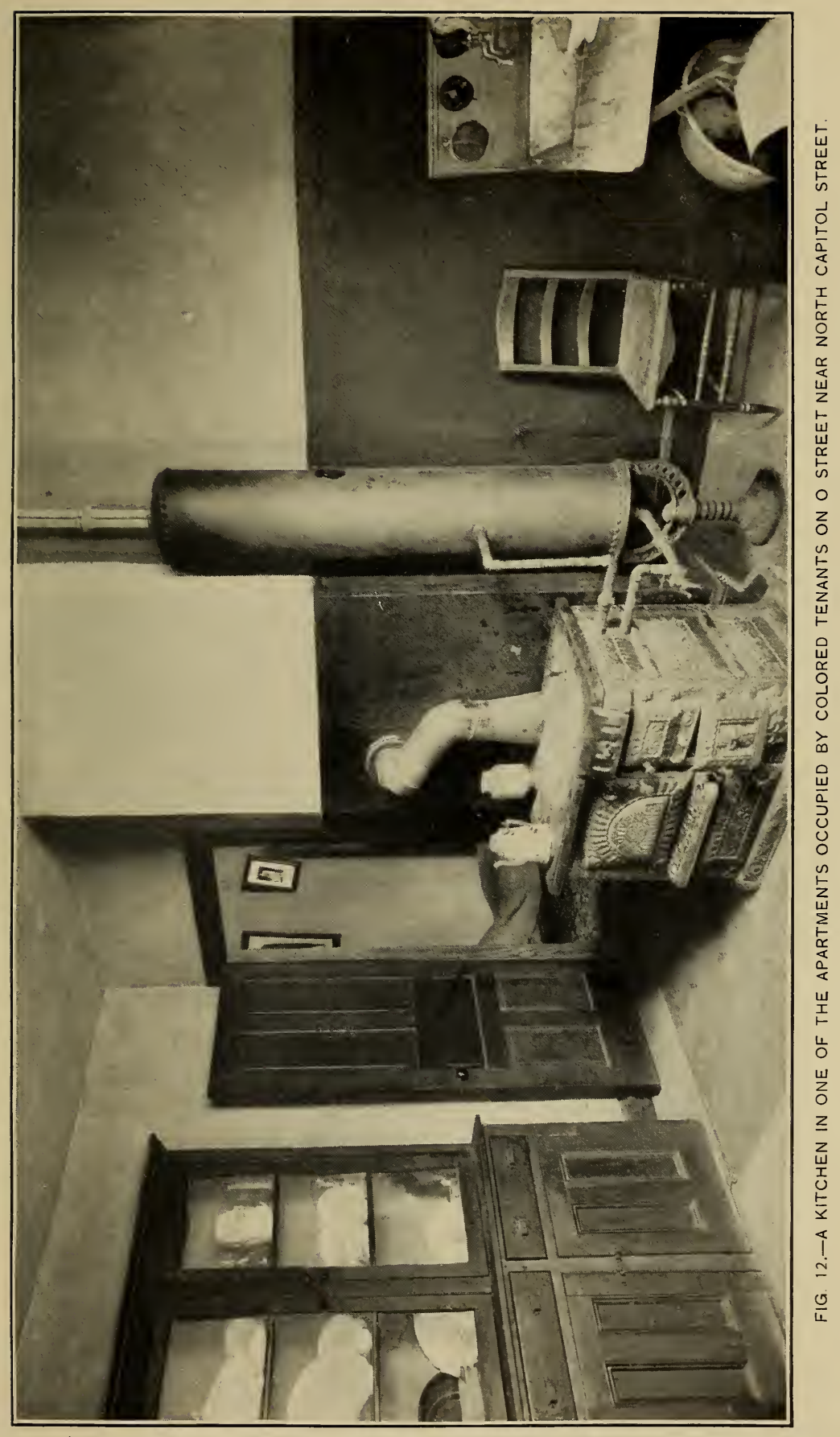



The Washington Sanitary Improvement Company has built 200 houses upon this plan, the Washington Sanitary Housing Company 40 houses, and various builder's who have copied the plan at least 1,200 more. The first eight houses of this type were completed and rented by November 15, 1897, the four-room flats renting for $\$ 12$ or $\$ 12.50$ per month, and the three-room flats for $\$ 9.50$ and $\$ 10$, with a rebate of one month's rent every year to tenants whose apartments have not required any repairs. In the houses built by the Sanitary Housing Company the cellar is omitted and, as the dividends in this company are limited in its charter to 4 per cent, it has been possible to give the tenants the benefit of still lower rentals. The three-room flats on Van street SW., shown in figure 9, are rented for $\$ 7.50$ per month, and four-room flats at $\$ 8.50$. Each of these flats also has a bath, with hot and cold water. All are occupied by colored tenants.

Owing to the increased cost of land, of material, and of labor, the Sanitary Improvement Company in subsequent building operations was unable to give rentals as low as those fixed for the houses built in 1897. But the company has recently acquired a large square of land in southwest Washington at a very moderate cost, and has commenced building houses of the same type, which will be rented to colored tenants at $\$ 3$ or less per room, including bath and back yard, but without cellars. The Sanitary Housing Company will gladly continue its building operations as soon as additional subscriptions to its capital stock can be obtained, but in the present state of the money market it is difficult to obtain subscriptions to a 4 per cent stock.

The latest floor plans of the Sanitary Improvement Company are shown in figures 13 and 14, and the specifications for these houses are given in full for the benefit of those who may wish to copy them.

Specifications of the labor and materials to be used in the erection and completion of 29 two-family houses facing on One-half street between is and $\mathbf{N}$ streets SW., for the Washington Sanitary Improvement Company, according to plans prepared by A. P. Clark, jr., architect, Union Trust Building, Washington, D. C.

MAY 22, 1908.

GENERAL.

The contractor to take out and pay for all permits; locate the lots, walls, fences, etc., by official surveys at his expense, and perform the work in accordance with the regulations and ordinances of the District of Columbia.

The plans and specifications are intended to cooperate and things shown or mentioned in one and not in the other are to be executed the same as if shown or mentioned in both and are intended to include everything requisite and necessary to the entire finishing of the work, notwithstanding every item necessarily inrolved is not particularly mentioned.

The contractor will make all of the houses complete in erery respect as may be shown on the drawings or mentioned in the specifications, and everything applying to one house of the same class.

The drawings of the floor plans, and the details indicated are only for the purpose of showing the type of house of each respective kind. The details of some of the houses being omitted for the sake of brerity and to aroid needless repetition.

All of the work to be delivered at completion in a perfect and undimaged state, the houses to be thoroughly cleaned, floors and glass washed.

The contractor will insure the buildings for at least the amounts paid on the contract from time to time, and the policies to be made parable for the benefit of whom it may concern.

The contractor will give a bond for the performance of all of the (onditions of the plans and specifications and contract. 
The contractor will state in his proposal the cost for additional foundation work as follows:

Excavation per cubic yard.

Concrete per cubic yard.

Brickwork per thousand.

The contractor wili make estimates on each block of houses, also for fences. as follows :

First. According to the plans and specifications as drawn and shown by sheets Nos. 1 to 6 , inclusive, 10 and 11 which provide for the buildings to have red brick fronts, 13-inch party walls, and back porches of wood.

Second. The amount to be deducted if the party walls from the first story up are built 9 inches thick instead of 13 inches.

Third. Amount for rear fences and gates of wood.

\section{EXCEPTIONS.}

The owner will furnish and set the following:

Ranges, stores, and gas fixtures.

\section{EXCAVATION AND SODDING.}

Excavate for foundations of the sizes and depths required to carry out the purposes of the plans.

Fill in around walls and tamp the earth in solid and grade from the buildings.

The space below the first floor will be cleaned out level and free of all débris.

Remove surplus earth and deposit same on the eastern half of the square near South Capitol street.

Sod the entire parking spaces with good clover and grass sod on bed of rich soil 3 inches thick.

The rear yards will be graded.

\section{CONCRETE FOUNDATIONS.}

Lay concrete foundations near all walls, piers, etc., as indicated on the plans 12 inches thick, composed of one part fresh natural cement, two parts clean sharp down river sand, and four parts of clean broken stone not orer 2 inches in diameter, thoroughly mixed and rammed in place.

WALKS AND STEPS.

Use high-grade Portland cement, clean sharp sand, and clean washed gravel not over $1 \frac{1}{2}$ inches in diameter.

Lay the walks in the front parkings, build the steps, cheeks and platforms, and foundations thereof, bases of light shafts; build the steps and platforms from the first-floor kitchen doors to the yard, and build the walks across the rear of the house, and provide bases 6 inches high to receive the wooden posts of the porches.

All to be composed of a base not less than 4 inches thick or a body formed of concrete, composed of one part cement, three parts sand, and five parts gravel, thoroughly rammed and compacted.

Build bolts into the concrete work to secure railings, balustrades, and posts in place.

Finish all of the above work with coat 1 inch thick, composed of equal parts l'ortland cement and clean sharp sand, troweled to smooth eren surfaces.

\section{BRICKWORK.}

The street fronts of buildings and yard walls of each house the width of the porch and chimneys above roof of house will be faced with select red brick of a uniform color.

The exterior walls elsewhere to be faced with hard red brick.

All brickwork for the interior facing of the exterior walls, and all brickwork below the first-floor joist, will be hard red brick.

The party walls above the first-floor joist may be built of merchantable brick, but if salmon brick are used they must be of first quality. 
All brickwork up to the first floor level and chimneys above roof, except the exterior facing, will be laid in one part natural cement and two parts clean sharp sand.

All other brickwork to be laid in rich lime mortar, composed of best Washington lime and clean sharp sand.

Walls and piers to be carried up perfectly straight and plumb, worked in regular bond and tied in every sixth course, joints to be laid solid throughout and neatly pointed where exposed.

Lay a double course of heavy black slate in all walls and piers at the ground line.

Turn arches over all openings and in walls where sewers pass under, the brick in the street fronts to be cut accurately to the radius of the arches, straight arches will be cambered.

Line the flues from beginning to top with terra-cotta pipes, the pipes to be set in place and the brickwork built around them, and joints struck smooth inside.

Place terra-cotta thimbles to each flue, making two to each apartment.

Place 5 by 9 inch cast-iron vents in walls to roof space and below the firstfloor joist in both front and rear walls and walls at base of light shaft.

Build wood blocks in walls to attach frames, baseboards, etc., to.

Place wood lintels over all openings and sills to windows.

Anchor the exterior end walls at second floor joist with $T$ anchors set 6 feet apart and two anchors into the front and rear walls of each house at the second floor joist.

Anchor wall plates with $\frac{1}{2}$-inch bolts, 2 feet 0 inches long.

STONEWORK.

The front door sills to be of Ohio stone $7 \frac{1}{2}$ by 14 inches.

All window sills in the street fronts will be of Ohio stone 5 inches thick.

The sills of all rear doors and windows will be of Ohio stone 3 inches thick.

All of the foregoing stonework will be stock pattern, the sills to have beveled upper surface.

IRON WORK.

Put up balustrades to the front platforms on each exterior coping and the intermediate coping between doors, composed of 2 -inch standards and $1 \frac{1}{2}$-inch rails with cast-iron top to the standard, to be securely and firmly anchored to bolts in the cement work.

SHEET-METAL WORK.

The cornices of the street fronts will be of sheet copper of the designs shown, the sheets thoroughly soldered and riveted and fastened to wood furring set in brickwork.

Run hanging gutters to main roofs in the rear with down spouts from each house to the sewer connections of galvanized iron.

Place skylights over hallways where indicated with galvanized framework and glazed with ribber glass 5-18-inch thick.

Place a panel in the end of each skylight controlled by cords from below.

ROOFING.

Cover fire walls, scuttle curb, and covers and do all necessary flashing with sheet zinc.

The main roofs of the buildings and porches and roofs of fuel bins will then be covered with a standard four-ply slag rooflng, as follows:

The rosin-sized sheathing paper or unsaturated felt to be used shall weigh not less than 5 pounds per 100 square feet.

The tarred felt shall weigh not less than 14 pounds per 100 square feet, single thickness.

The pitch shall be of the best quality of straight run coal-tar pitch, distilled direct from American coal tar, and there shall be used not less than 120 pounds (gross weight) per 100 square feet of completed roof.

The nailing shall be done with three-penny barbed wire roofing nails driven through tin disks. 


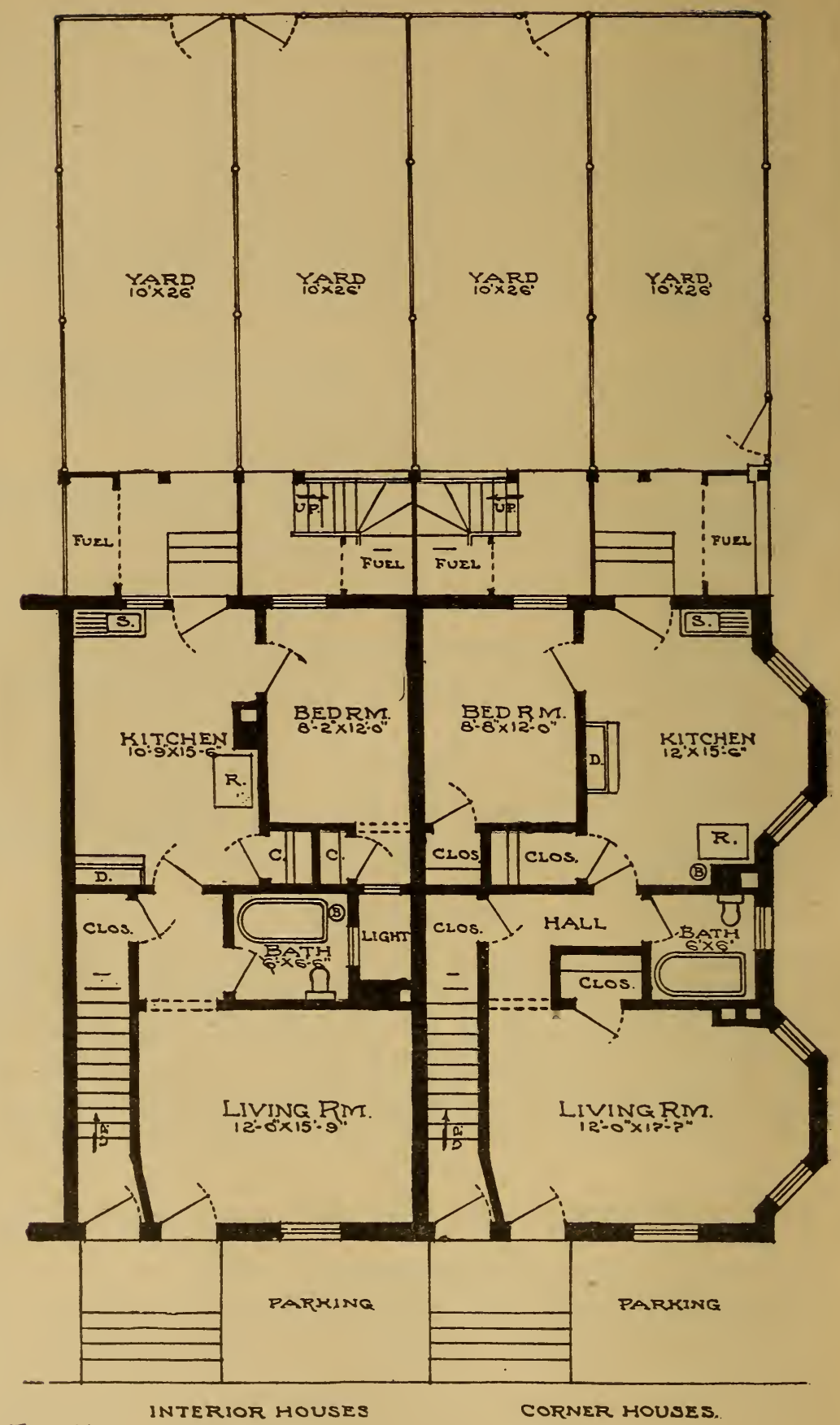

Fig. 73.

- firstfloor plan. 


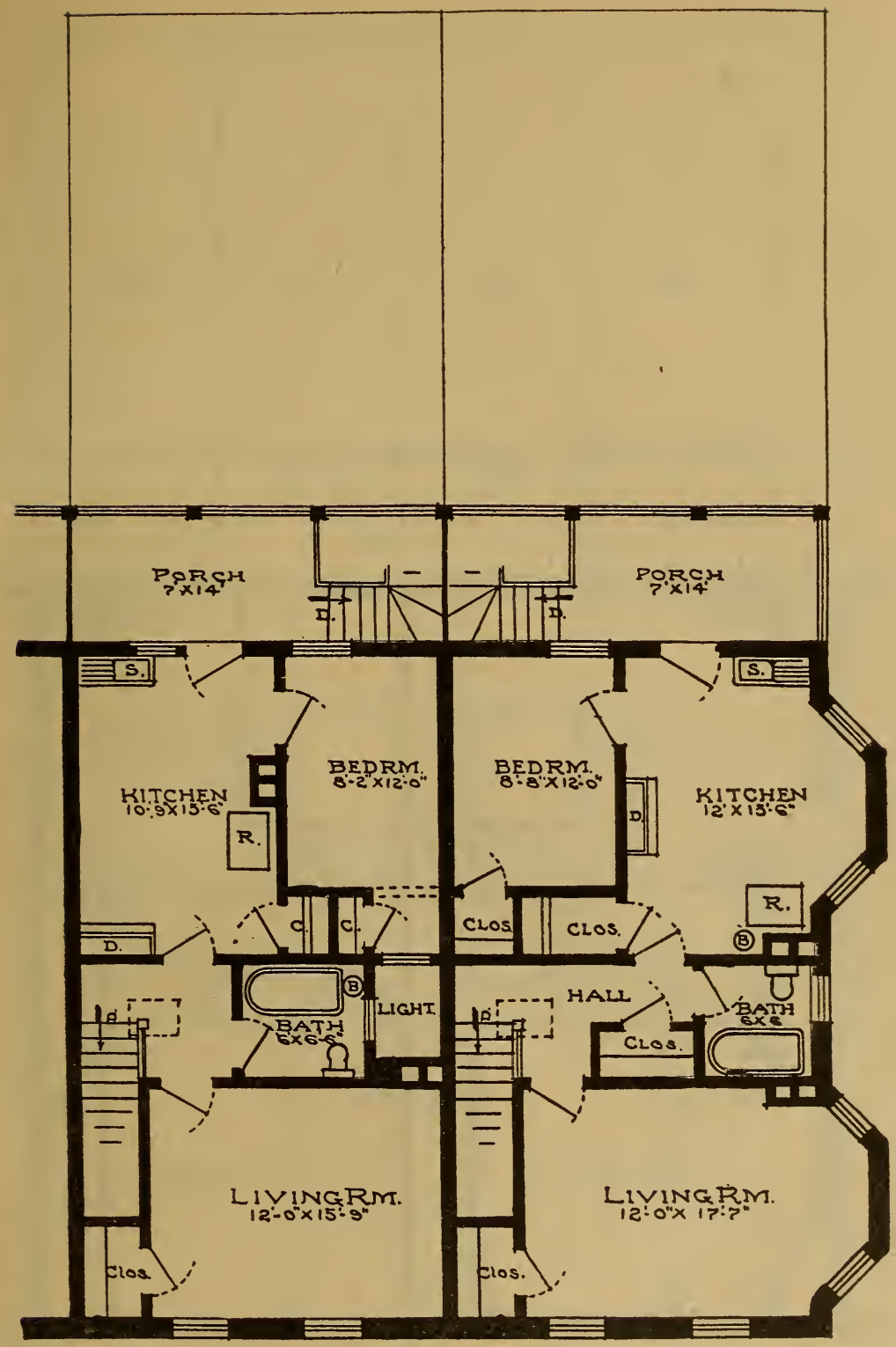

Fig. 13. -SECOND FLOOR.PLAN.

- THREe Room two family Houses.

- For Washington sanitarylmprovementCo. - HALFST. BET.M\&N.STS. S.W.$\operatorname{SCALE⿱⺌兀冖\zh13 g~}=1 F T$. 


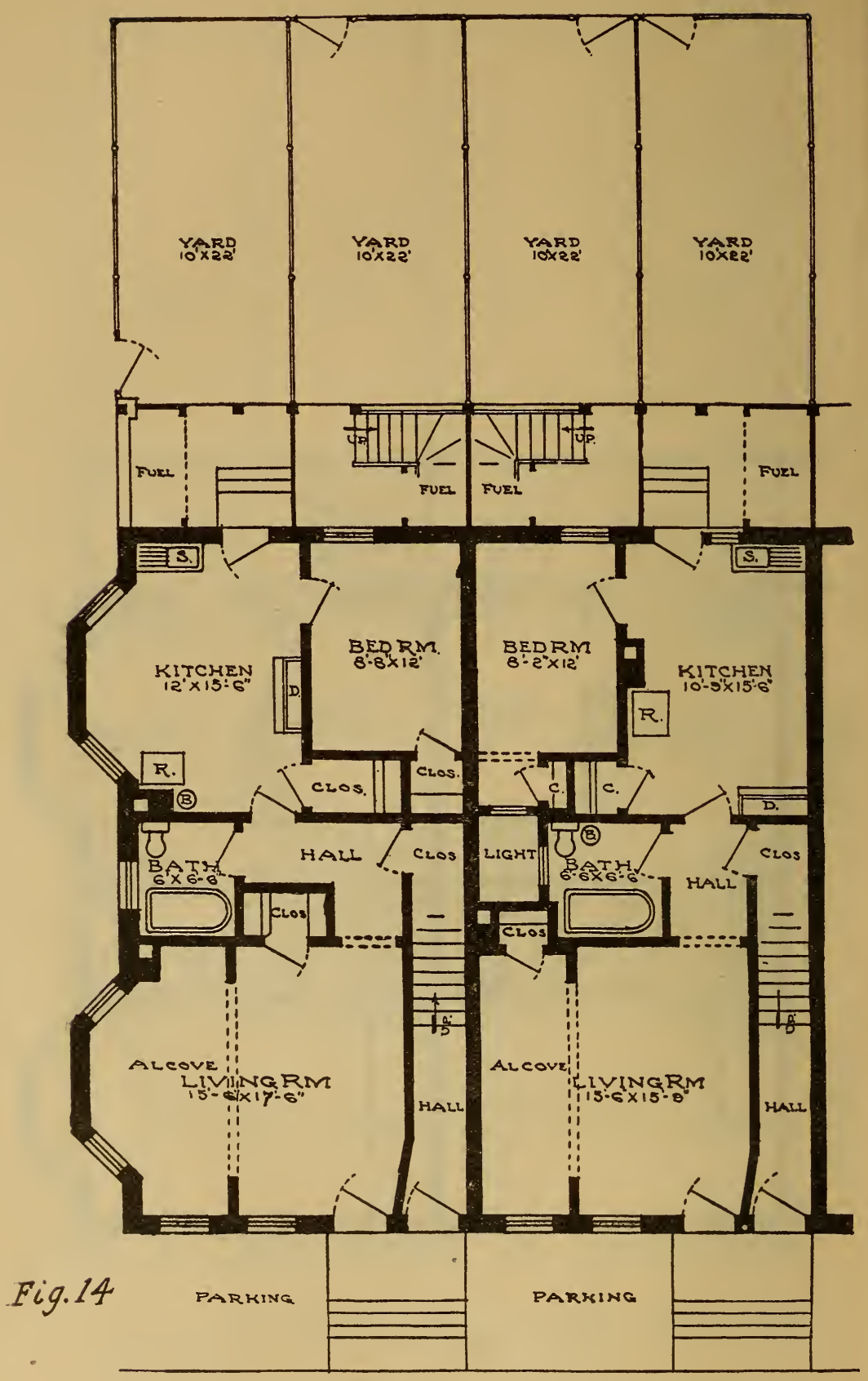

CORNER HOUSES

INTERIOR HOUSES

- firstfloor plan. 


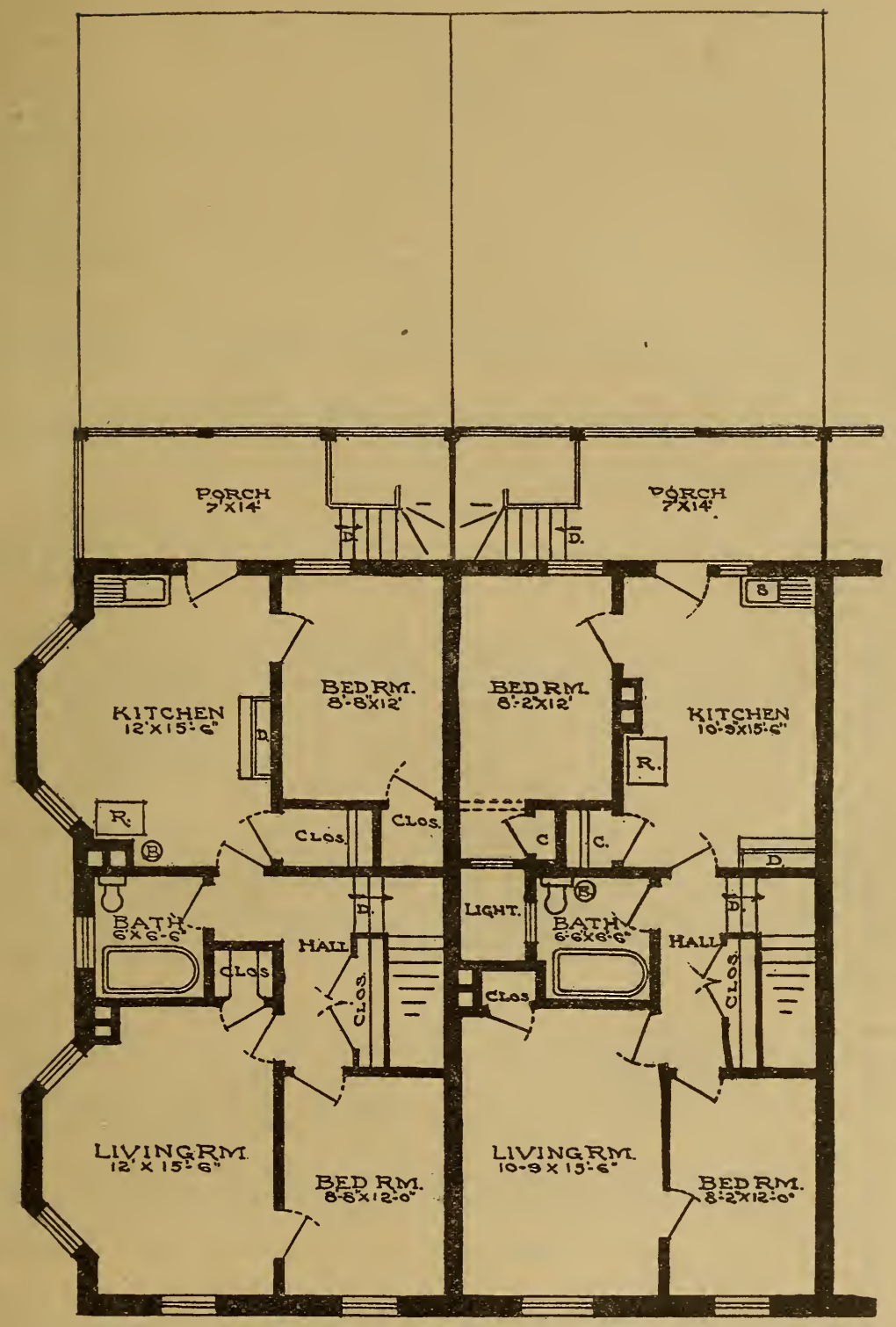

Fig. 14 .

-SECOND FloORPLAN.

- Four room two family Houses.

- For WASHINGTON SANITARYIMPROVEMENTCO. - HalFST. BET.M.\&N.STS. S.W. •

S CALE $\frac{1}{8} 3 N=1 F T$.

S. Doc. $599,60-2-4$ 
The slag or gravel shall be of such a grade that no particles shall exceed $\frac{5}{8}$-inch or be less than $\frac{1}{4}$-inch in size. It shall be dry and free from dust or dirt. In cold weather it must be heated immediately before using. Not less than 300 pounds of slag shall be used per 100 square feet.

The materials shall be used as follows:

First. Lay one thickness of rosin-sized sheathing paper or unsaturated felt lapping, each sheet 1 inch over the preceding one, and nailing only so often as may be necessary to hold in place until covered with the tarred felt, and the nailing may be omitted entirely if practicable.

Orer the resin-sized sheathing paper or unsaturated felt lay two full thicknesses of tarred felt, lapping each sheet 17 inches over the preceding one and nailing along the exposed edges of the sheets only so often as may be necessary to hold the sheets in place until the remaining felt can be applied.

Orer the entire surface of the felt thus laid spread a uniform coating of pitch, mopped on. Then lay three full thicknesses of felt, lapping each sheet 22 inches over the preceding one and nailing as laid every 3 inches not more 10 inches from the upper edge.

When the felt is thus laid and secured, mop back with pitch the full width of 22 inches under each lap. Then spread over the entire surface of the roof a uniform coating of pitch, into which, while hot embed the slag.

\section{WOODWORK.}

All of the woodwork herein specified to be of the best of the several kinds, well seasoned as the market affords, and free from defects impairing its strength and durability.

The girders below the first floor, posts in first story below porches, and carriages of outside steps will be of prime Georgia pine.

All of the other framing lumber to be of No. 1 Virginia pine, except that porch timber such as posts in the second story and balustrades, steppings, etc., will be of North Carolina pine.

The interior of the buildings throughout will be finished in bright Virginia pine, free from blue or white sap, except that doors will be of white pine for the exterior and of stock pattern.

The doors for the interior will be of No. 1 stock pattern white pine or stock pattern veneered birch, either of four, five, or six panels.

Provide girders of Georgia pine under the first floor as indicated on the basement plans, and from them erect posts of Virginia pine carrying the girder which will assist in supporting the second-floor joist.

The floor joists in first and second stories will be 2 by 10 inches, set 16-inch centers.

These floor joists will have 4 inches bearing on walls, double framing, and under partitions, leveled up with slate chips, and shall be brought to a perfect level along the upper edges. Each span to have two rows of cross bridging 1 by 2 inches of Virginia pine.

Ceiling joists and rafters to be 2 by 8 inches, set 16 inches on centers.

Put up studding throughout and about the light shaft with 2 by 4 inch studs set 16-inch centers.

Do all necessary furring to cover pipes, from arches, etc.

Sheath all roofs with Virginia pine boards 1 inch thick, securely nailed to each bearing.

The sheathing over the exposed eaves, if such is used, will be dressed and beaded face downward.

The rafters in projecting eaves, if such are used, will be dressed and sawed to simple patterns.

Frame the porcl with 6 by 6 inch posts in the first story and 4 by 4 inch posts in the second story.

Frame the second-story floor with 3 by 10 inch cross sills and 2 by 8 inch joists set 18 -inch centers.

The rear porches will have the flooring of the second story of heart Georgia pine $\frac{7}{8}$ inch thick by $2 \frac{1}{2}$ inches wide, laid with white-leaded joints.

Put up balustrades of North Carolina pine with 2 by 4 inch rails and $\frac{7}{8}$ by $1 \frac{1}{4}$ inch balusters.

Construct the steps to the rear yards with 2 by 12 inch carriages and $\frac{7}{8}$-inch North Carolina pine treads.

Put up balustrades of two 2 by 4 inch hand rails on sides of steps where open. 
Put up partitions between yards and between porches of each house and each apartment, $\tau$ feet high set in place as a panel, tongued-and-grooved boards 3 inches wide, with screws.

The partitions between the apartments where there are staircases coming together will extend from the liead of balustrade above the steps down to the ground.

The rear porches under roofs will be ceiled with Virginia pine boards $\frac{1}{2}$ inch thick by 4 inches wide, set $\frac{1}{4}$ inch apart.

Build fuel bins in the first story of the rear porches with sides and roofs as indicated on the plans.

All lumber in porch framing, including posts, balustrades, ceilings, steps, etc., will be dressed.

WINDOWS.

Box frames to be of stock yattern, with $1 \frac{3}{8}$ by $1 \frac{3}{4}$ inch hanging stiles, $1 \frac{3}{8}-$ inch subsills, $\frac{7}{8}$-inch pulley stiles, have steel axle wheel pulleys, the pulley stiles to be of North Carolina pine.

All sash to be $1 \frac{3}{8}$ inches thick hung with best hemp cord to cast-iron weights, evenly balanced.

Sash in the alcoves of the first stories of the four-room houses will be pivoted.

All windows will have outside blinds $1 \frac{3}{8}$ inches thick of white pine, panels filled with stationary slats, except the small windows in the alcoves, the windows to bathrooms on light shafts, and kitchen windows of all houses except the corner houses.

DOORS.

Frames to be $1 \frac{3}{4}$ inches thick of white pine.

Exterior doors to be $1 \frac{3}{4}$ inches thick of white pine, sash doors, as indicated.

Interior jambs to be $1 \frac{3}{8}$ inches thick of bright Virginia pine.

All interior jambs will be stock patterns from four to six panels and may be either No. 1 white pine, or of reneered birch.

FLOORS.

Lay finished floors throughout the buildings of No. 1 Virginia pine, $\frac{7}{8}$ inch thick, $2 \frac{1}{2}$ inches wide, well driven up, and blind nailed to each bearing.

The first-story flooring will be laid after plastering and second-story flooring will be covered with paper during plastering, and due care must be exercised to keep floors covered during the plastering.

Strike joints smooth throughout on completion of work.

STAIRS.

The stairs will be built of three 2 by 12 inch carriages, treads to be of North Carolina pine $1 \frac{1}{8}$ inches thick, risers of North Carolina pine $\frac{7}{8}$ inch thick, plowed together, treads nosed and molded.

Cut the baseboard down to the line of the steppings.

Put up balustrades where indicated in the second story with 2 by 4 inch hand rails, 4 by 4 inch posts, and $\frac{7}{8}$ by $1 \frac{1}{4}$ inch balusters, set 2 inches apart.

Put up 2 by 2 inch hand rails to all staircases supported by iron brackets set 4 feet apart.

INTERIOR.

Trim openings throughout with $\frac{7}{8}$ by 4 inch moldings.

Window jambs $\frac{3}{4}$ inch thick, window sills $1 \frac{1}{4}$ inch thick, baseboards to be $\frac{7}{8}$ by 7 inches with $\frac{3}{4}$ by $1 \frac{1}{4}$ inch shoe.

Furnish and set up in the kitchen, securely attached to the building, No. 1855 modified McDougall cabinets (get price from architect).

Plovide shelving in all closets as indicated on the plans.

Put up $\frac{3}{4}$-inch molding above cement wainscoting in kitchens, bathrooms, and hallways.

HARDW ARE.

Numbers are taken from the Yale \& Towne Manufacturing Company catalogue; finishes to be bronze or bronze plated, as designated by the number called for. 


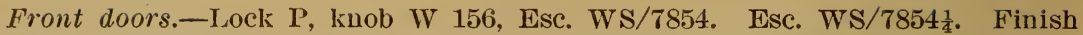

BZ 10. Hinges $241 \frac{1}{2}, 4$ by 4 inches. Finish SBZ 10 .

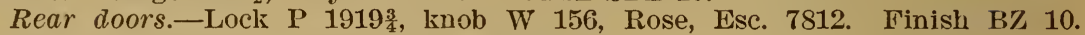

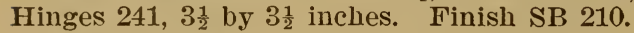

Interior doors.-Lock P 719, knob WT 50, Esc. W 2/1862. Finish B7 10.

Hinges $241,3 \frac{1}{2}$ by $3 \frac{1}{2}$ inches.

Closet doors.-Lock P 719, knob W 50, Esc. W 2/7862. Finish BZ 10. Hinges $241,3 \frac{1}{2}$ by $3 \frac{1}{2}$ inches.

Pivoted window sash. -1 1186-catch. 1 set W 52 pivots. $1 \frac{3}{8}$ inch by 3 foot lifter SBZ 10.

Transoms.--Spring pivots, SBZ 10. Transoms wd. adjusters.

Hooks.-No. 2513. Finish FBV/10. Set 8 inches apart in closets and 2 inches in bathrooms.

Door stops. $-2 \frac{1}{2}$ inches, plain.

Dressers. - No hardware.

\section{PLASTERING.}

The first and second stories are to be plastered throughout.

Put up union galvanized-metal corner beams on all projections.

All exterior walls to be thoroughly pitched on the inside or covered with other damp-proof compound.

Lath all partitions and ceiling with sound spruce laths, put up with good keys to suit either cement or lime mortar as hereinafter specified.

The walls of bathrooms, kitchen, hallways, and staircases to the secondstory apartments, from the entrance door up, to the height of 4 feet 6 inches in each case, will be plastered with one coat on lath work of one part Portland cement, two parts clean, sharp sand mixed with long cattle hair, with small quantity of hydrated lime therein.

Plaster all of the above work, both lath and brick, with second coating of Portland-cement mortar, to which a $\frac{1}{5}$ portion of marble dust will be added. and which is to be floated up true and troweled down perfectly smooth and even.

All of the plastering will be with the first coat of rich lime mortar mixed with best cattle hair, put on with sufficient force to secure strong keys and to be well scratched.

Plaster all work with second coating of rich brown mortar floated up true and even at all points.

Finish with lime putty gauged with best plaster, troweled to smooth, even surface to prevent checking.

In the finishing coat, use hydrated lime.

PAINTING AND GLAZING.

Clean-down woodwork to be finished.

Cover knots with shellac; prime frames on delivery at the building; do all necessary puttying in a careful manner.

All interior woodwork throughout will have one coat of oil filler, two coats of gutta-percha varnish, and one coat of flattine.

All exterior woodwork to be painted four coats of paint of best white lead and pure linseed oil.

Galvanized-iron work to have one coat of metallic paint and three coats of white-lead paint.

Tin work to be painted with two coats of metallic paint.

Ironwork to have one coat of metallic paint and two coats of white-lead paint. Place the number of houses on front doors of each apartment in black figures. Glaze all street-entrance doors with double-thick syenite glass.

Glaze the windows of the first-story rear bedroom with single-thick syenite glass.

Glaze the lower sashes of all windows and of sash doors with No. 1 American double-thick glass.

All other glazing to be of first quality single thick American glass.

BELLS.

Place bells about the center of each apartment with mechanical pulls at each front floor, having stamped gold-bronze pulls. 
FENCES.

Make estimate for fences of wood constructed as follows:

Posts of cedar not less than 6 inches in diameter, set not over 8 feet apart. Two rails of Georgia pine 2 by 4 inches.

Boarding of Virginia pine 1 inch thick, 6 feet high. Boarding of street fronts to be dressed and painted three coats.

Place one gate to each yard, hung with strap hinges and have hooks inside.

The following account of houses costing less than $\$ 2,500$, which have been built in Washington during the past five years, has been prepared for the committee by Dr. Henry C. Macatee:

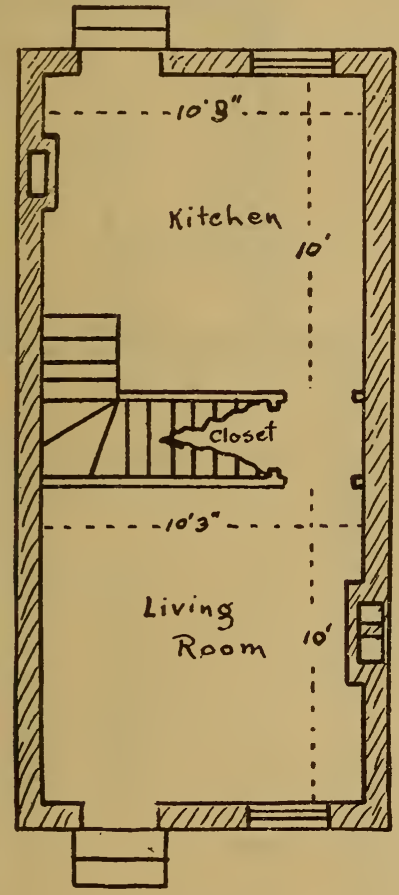

1st. Fioor.

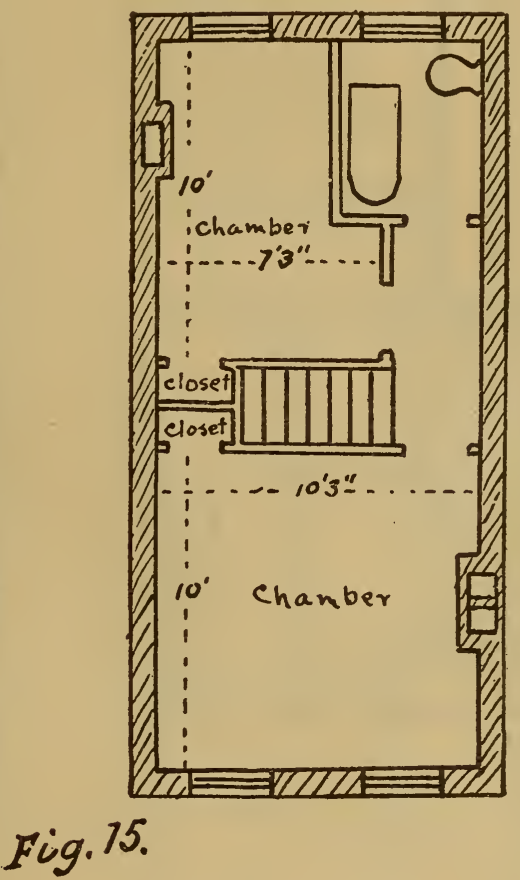

Fig. 75 .

and Floor.

TYPES OF NEW DWELLINGS OF LOW COST IN WASHINGTON, D. C.

It will be shown in the chapter on the house famine that little or nothing has been done in the past five years by ordinary commercial activity in the way of building dwellings for the least resourceful people. Not one dwelling erected within that period was found which could be rented for $\$ 12$ a month. There have been erected, however, a few dwellings of a desirable type, perhaps not above 15 in the entire city, which may be rented for from $\$ 14$ to $\$ 16.50$. The plan of this type is shown in figure 15 .

There is nothing new in this type of house, but the requirements of the building regulations have greatly improved their quality. They are all well above the ground level, are ventilated under the 
ground floor, and have back yards of sufficient size. They are light, dry, and are supplied with bathroom and water-closet. They are heated by stoves and are provided with a kitchen range, which supplies hot water to the bath and sink. Two of these, however, had no provision for hot-water supply, all the stoves being furnished by the

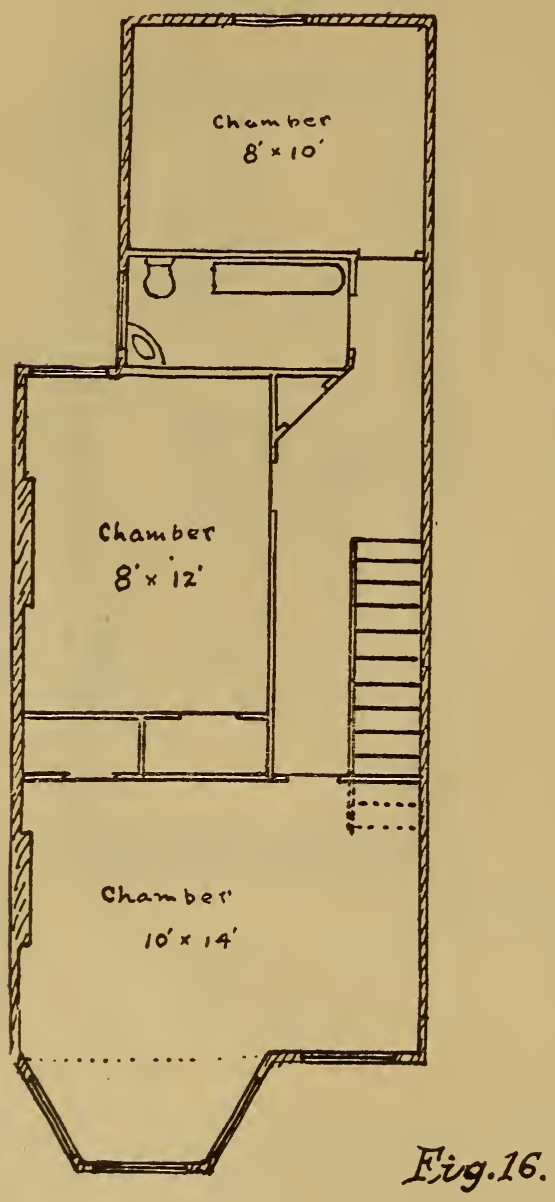

2nd. Floor

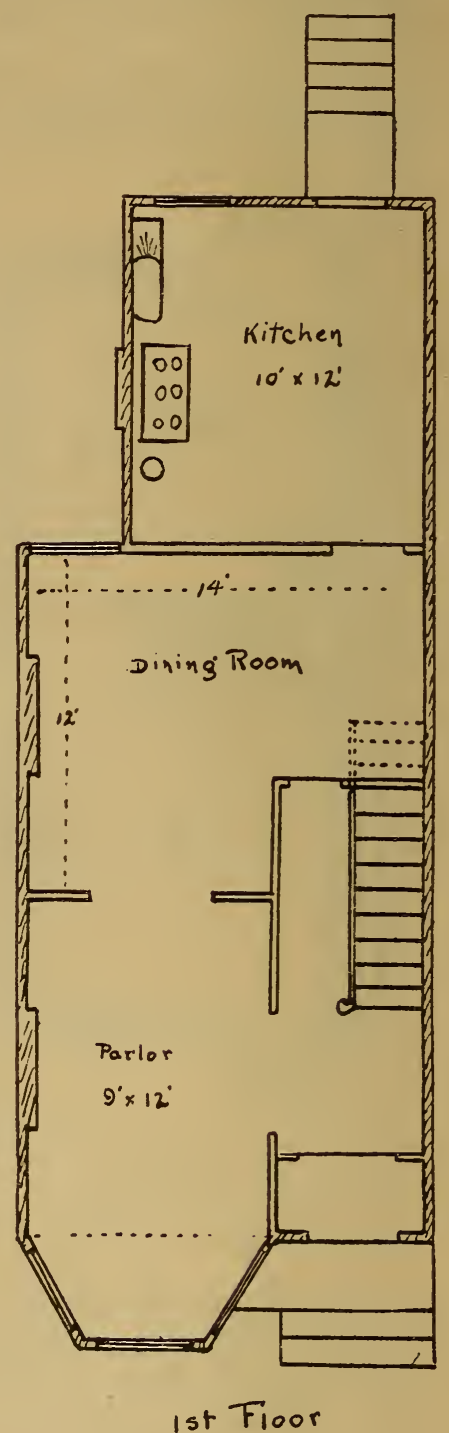

occupant. The estimated cost of such dwellings was given as approximately $\$ 1,200$. Most of them are located in Georgetown and are occupied by colored tenants.

An observation of interest made in visiting houses occupied by colored people was that in most instances the gas meter had been removed, oil lamps being used instead of gas. Fear of the gas was 
the explanation given for this in several instances, and inquiry elsewhere tends to confirm the statement. It is quite possible, however, that the deposit required to secure gas service, the mandatory character of gas bills, and the frequency of change of abode may be the true explanation. Might not this fact make it desirable to save the

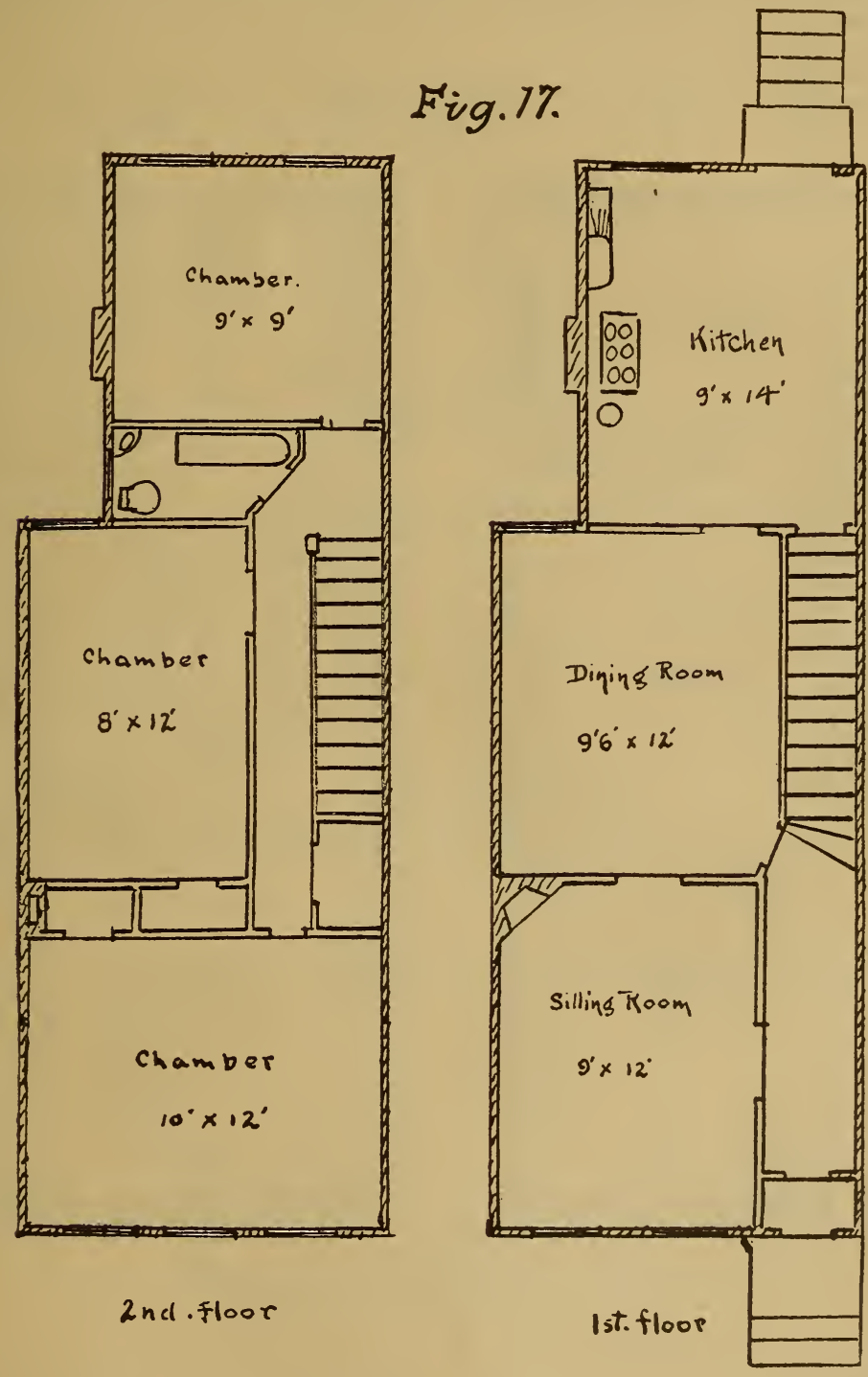

cost of installing gas piping and fixtures in cheap dwellings intended for colored tenants and thus further reduce the rentals?

The great majority of new dwellings of low cost are of one general type-six rooms and bath, two stories in height. Figures 16 and 17 illustrate two varieties of the type most frequently seen, the width of the lot determining whether the stairway shall be closed or whether 
there shall be a thoroughfare hallway. Very many dwellings of this class have been built and are building on desirable streets and avenues all over the city. Such houses are ventilated under the ground floor, or frequently have a large concrete cellar; in the first instance they are heated by latrobes, in the latter by furnaces. There is a grass plot in front usually; entrance is through a tiled vestibule; within,

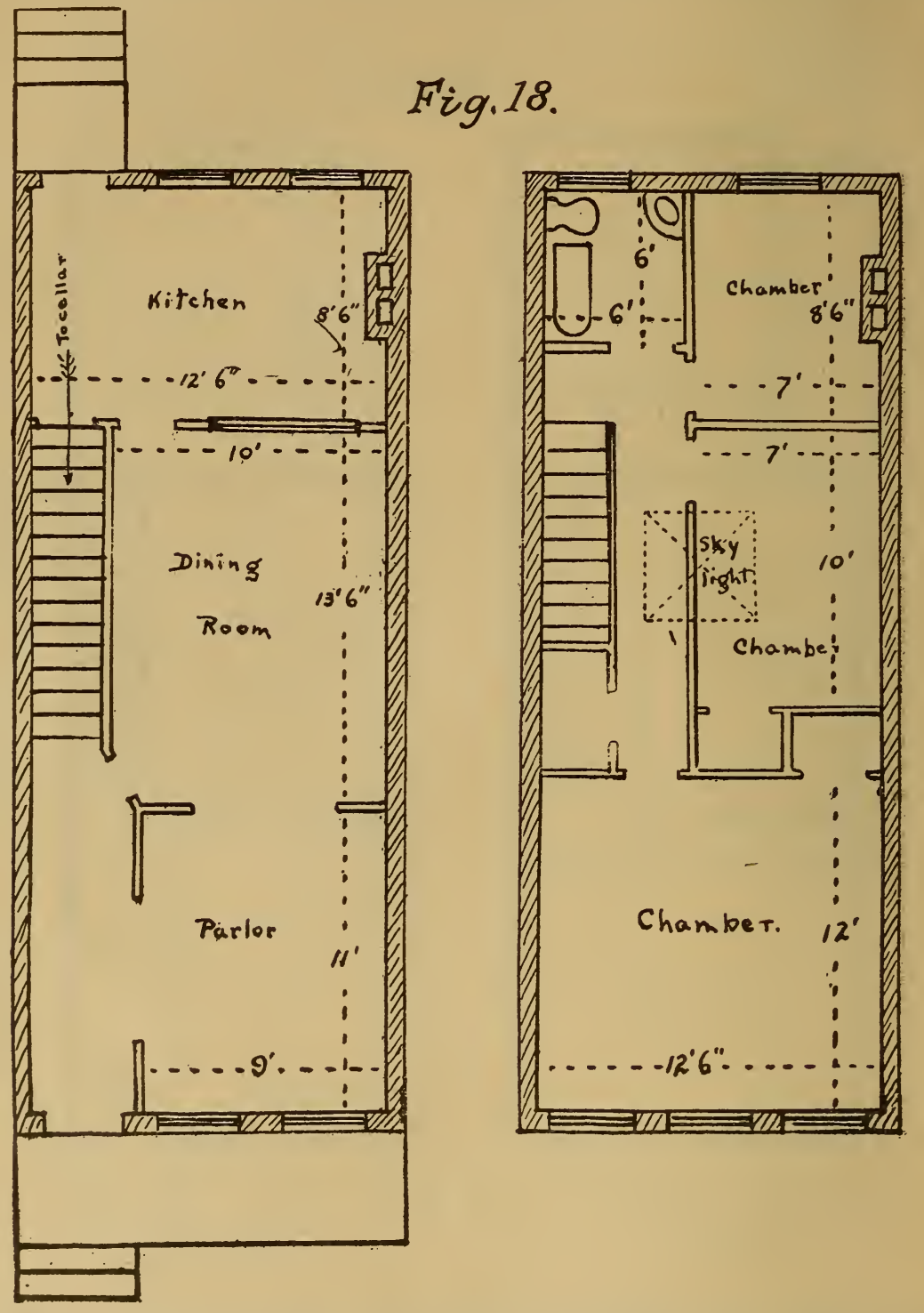

the woodwork is pleasing, the rooms commodious, the walls nicely papered, the bathroom tiled; there is a good yard in the rear, often a porch, and nearly always exit on an alley. Such dwellings are supplied in adequate numbers, and leave no ground for criticism from a sanitary standpoint. It may be noted that not a few colored people 
have availed themselves of these homes, even when they are of such circumstances that the women have to do laundry work to help pay the rent of $\$ 20$ or $\$ 25$ which these houses bring.

Figure 18 illustrates a type in which the entire width of the lot may be utilized. It may be seen that the dining-room and one bed room have no outside windows; the dining-room being lighted by cross illumination through the parlor and kitchen, and the bedroom
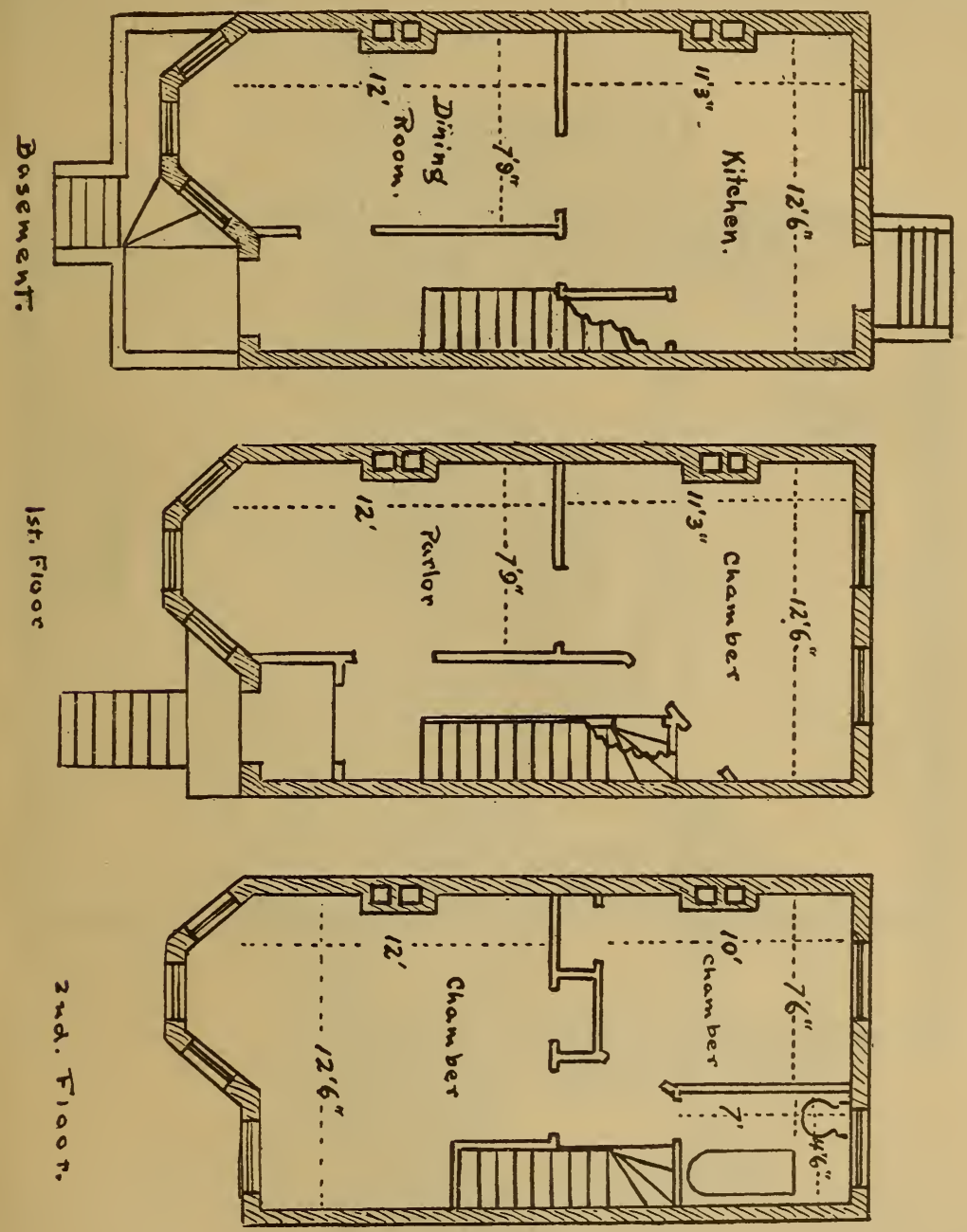

FIG. 19.

being provided with a skylight. Inspection of these dwellings, of which there are many in the southeast, demonstrated that ample light reaches both rooms.

A type adapted particularly for short lots, frequently to be seen about the city, is illustrated by figure 19 .

Very few of this variety have been built recently, but there are so many of the kind in the city that it is of interest to note the type, and. 
on account of the basement rooms, it is a matter of satisfaction to note the passing of the type from general use.

A design not seen until 1907 is illustrated by figure 20 .

Houses of this kind are always provided with a cellar and are furnace heated; in the kitchen a gas range only is supplied, hot water for domestic purposes being supplied from a coil in the furnace in winter and from a gas water heater in the summer. This style of dwelling gives the impression of space and comfort, and the plan lends itself well to refinement of living. Such houses are estimated, according

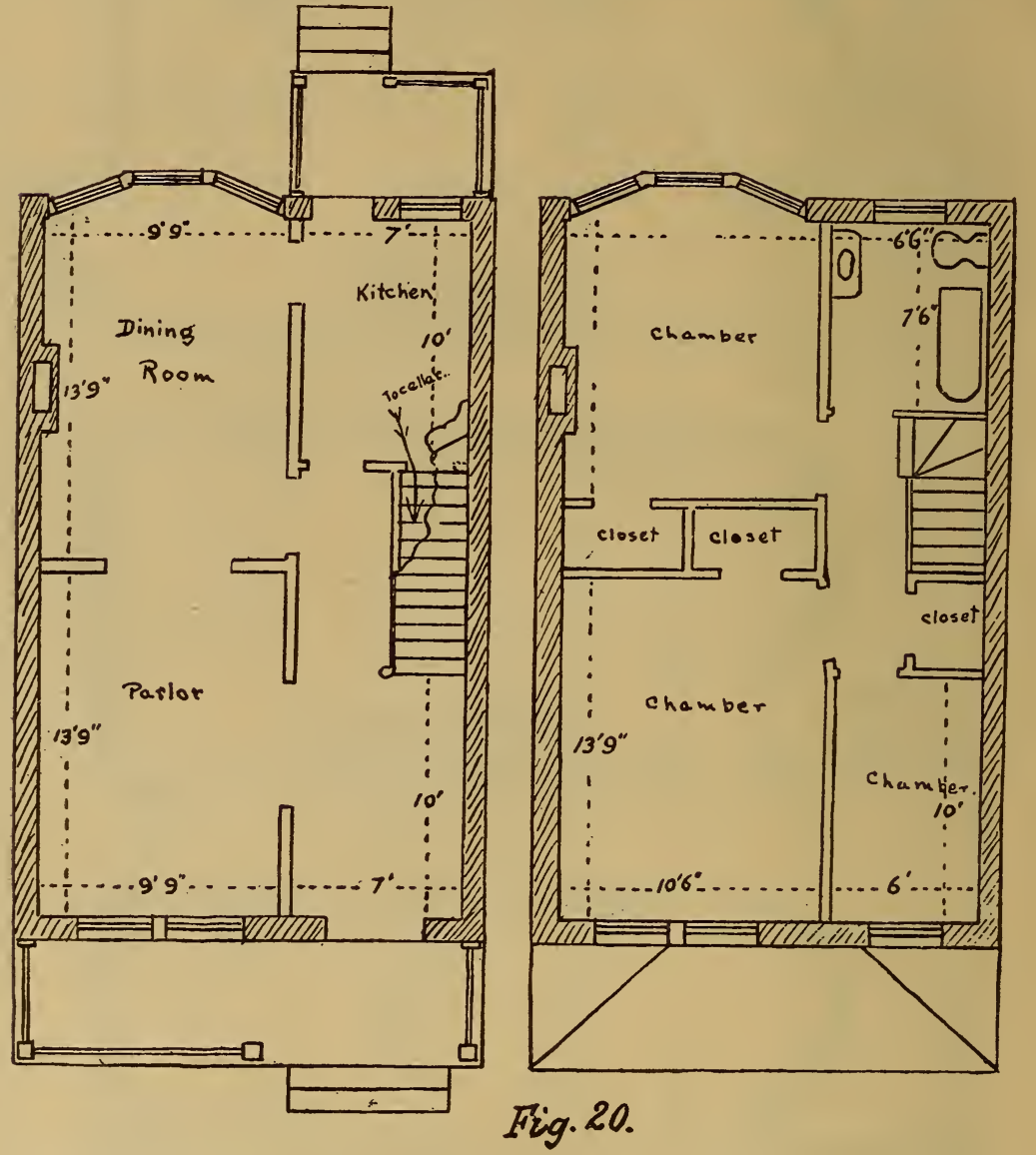

1st. Floor.

2nd. Fioor.

to the application for building permit, to cost from $\$ 1,500$ to $\$ 2,000$, but as they are put on the market for as high as $\$ 4,000$ and even $\$ 5,000$ for a corner house, the accuracy of the estimate given is questioned. Most of the houses of this type were built for sale and have been quickly sold; when rented they bring from $\$ 27.50$ to $\$ 35$.

It may be stated, therefore, that the type of brick dwellings of low cost erected at this period can not be criticised either on the ground of comfort or of sanitary construction and equipment. For the skilled laborer, the mechanic, the clerk, and other wage-earners of like resourcefulness, homes may be had in abundance and of the best 
quality. Nor can fault be found with the type illustrated by figure 15 ; these houses are very desirable, comfortable, and sanitary; but they are not being constructed in any considerable numbers. If they

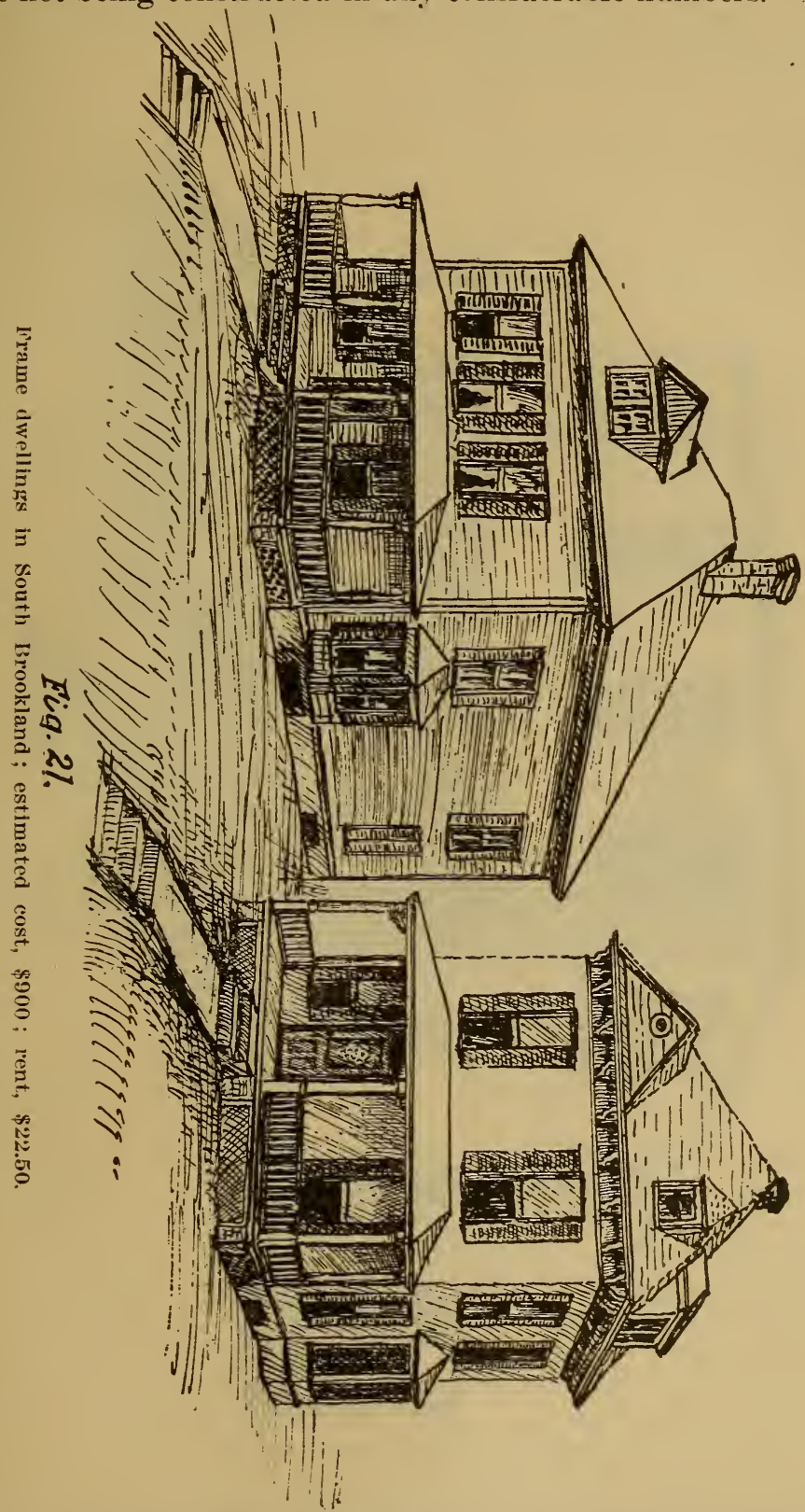

can be built and rented for $\$ 16.50$, their construction should be encouraged.

The two-family apartment houses are all of the same general plan as the four and five room flats of the Washington Sanitary Improvement Company, a full description of which has been given. A con- 
siderable number, however, have been constructed with a concrete cellar under the entire building, the cellar containing a separate furnace for each apartment and a fuel bin. All of these houses follow the plan of the Sanitary Improvement Company in providing porches and a back yard for each flat.

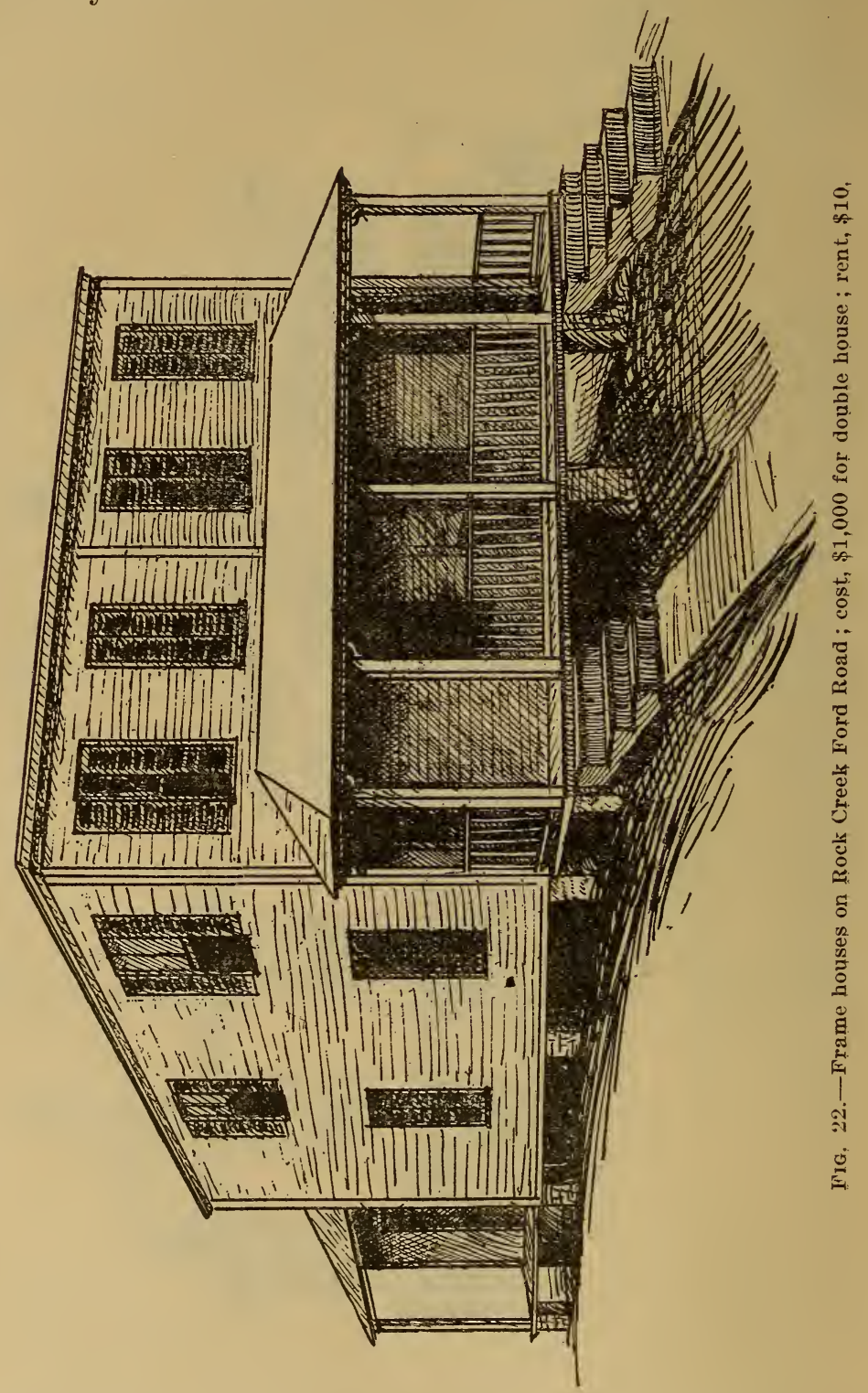

On the outskirts of the city and in the suburbs most of the dwellings are of frame construction. There are two general types to be seen :

(1) A cottage type, in which great diversity of floor plan and exterior finish obtains. Examples of this type are illustrated in figure 21. 
Drellings of this type are usually provided with furnace heat, and have water, gas, and sewer connections when these public utilities are available. They contain usually six or eight rooms, with bath; they have large porches and are surrounded by a yard, part of which may be utilized as a garden. The great majority of this type have been built and are owned by the occupants; none is available for the day-laborer class, because when rented they bring from $\$ 18$ to $\$ 30$ rent. The estimated cost, as given in the applications for building permits, is from $\$ 900$ up to $\$ 2,000$ for the kind of houses investigated, although there are many cottages of the bungalow plan, containing four and five rooms and bath, which were estimated to cost from $\$ 500$ to $\$ 750$. The great majority of the suburban, dwellings recently erected belong to this cottage type. Far out, of course, the water supply is obtained from wells, and the water-closets give place to box privies, but even here many of them are built with a bathroom, anticipating the extension of the public water supply. The more costly houses have a tank in the attic from which running water is distributed through the house, the tank being filled by hand pump,

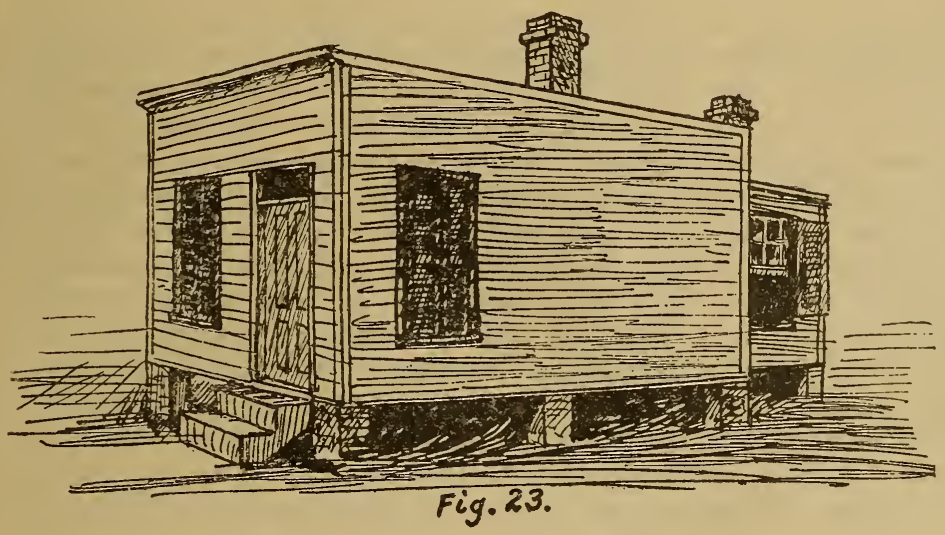

Frame dwelling in Deanwood; cost, $\$ 200$; rent, $\$ 6$.

gasoline engine, or windmill, the waste water being cared for in a cesspool.

(2) A type of frame dwellings built for renting purposes exists in limited numbers. Figure 22 illustrates this type wherever seen, although they are not always built double, as in the illustration.

Such houses are of the plainest construction; no ornamentation outside, bare plaster inside; they are heated by stoves; have no bath nor water-closet, and obtain water in some instances from a hydrant in the yard, more often from a well in the yard, or from a well or hydrant in the neighborhood. These houses are identical in plan with many of the old frame dwellings which are a present source of trouble in the city, but the new ones are sound, plumb, have water-proof roofs, and are dry because they are usually set upon brick piers. Colored people usually occupy these houses and pay $\$ 10$ for them, whether near the city or far out on some county road. Rather better houses of the same type, but with larger rooms and set upon wall foundations, with some slight ornamentation about the exterior, shelter white tenants, and bring $\$ 15$ per month in rent. 
In addition to the two general types just described, there are many habitations of a typical sort, which have been built in communities like Deanwood, Burrville, and Barry Farm by colored people at a cost of $\$ 200$ to $\$ 100$. These houses are two or three room structures, usually one story in height, set upon piers, and without water supply; gas and sewer connections are out of the question. Figure 23 shows a dwelling of this sort in Deanwood; it is said to have cost $\$ 200$ and at present brings $\$ 6$ rent.

Most of these little houses are owned by their occupants, however, and there is no commercial movement to build such shacks. It may be of interest to note that according to information obtained from colored people in the Barry Farm neighborhood the shacks in that village are being bought by certain real-estate dealers as fast as they are offered for sale, and that as soon as they fall into the hands of these dealers the rentals asked are immediately advanced.

IV. TYPES OF HOUSES OCCUPIED BY THE LABORINY CLASSES IN PHILADELPHIA AND BALTIMORE.

For the purposes of this report a special investigation has been made in the cities of Philadelphia and Baltimore to ascertain the types of houses now being built in these cities for the laboring classes and the rents paid, especially by unskilled workmen. These cities have been selected because climatic and other conditions are similar to those which obtain in Washington, and there is a tendency in both these cities to provide independent homes for the working classes rather than to have them in tenement houses of three or more stories. The investigation of housing conditions in these cities has been made for the committee by Dr. H. C. Macatee, whose report follows:

The city of Baltimore has its housing problem, no less than Washington, as may be ascertained by perusal of a pamphlet published by the Association for the Improvement of the Condition of the Poor, entitled "Housing Conditions in Baltimore." But an inquiry into the question of construction and rentals of small dwellings reveals a wide difference between that city and Washington. In the older portions of Baltimore the same squalor and overcrowding, which as yet is a condition inseparable from urban life, exists as in our worst alley hovels; aggregation in large tenement houses obtains there also, but not to the extent that this eril has reached in New York and Chicago.

TVe wish, however, to see what is the state of affairs in the newer portion of Baltimore. There has been, and now is, great activity in the construction of small houses of low cost in the northeastern section of the city. Block after block of dwellings of the same type may be seen, some giving the appearance of well-seasoned habitations, some showing signs of recent occupancy, and others under construction.

Three features are so universally prevalent as to be characteristic of the city: (1) White marble trimmings and front steps; (2) cellars; and (3) frame extensions in the rear of the second story, overhanging the back yard.

(1) The white marble trimmings and front steps appear to be indispensable appurtenances to a respectable dwelling place. On fashionable streets, bordered by homes of the wealthy, or upon minor 
streets, giving access to monotonous rows of six-room dwellings, each doorway is guarded by a white marble pile of such immaculate cleanliness as to forbid approach. No matter what time of day, somewhere in the block may be seen the housewife or domestic on her knees, with scrubbing brush in hand, scouring this emblem of respectability. Even in rows where the cost has been so reduced as to preclude stone, the wooden steps are painted white, and scrupulous care is given to these also, for here and there may be seen a temporary portable bridge-like set of steps to give entrance to the house, while a fresh coat of paint is drying.

(2) Even the cheapest alley houses are provided with cellars, though in such cases unpaved. 'This customary excavation is a source of difficulty in older portions of the city because of stagnation of water, overflow of privy vaults, or because used for improper purposes, such as storage of edibles or keeping of poultry. In new dwellings, however, usually the cellar is cemented and well lighted, and provided with a hot-air furnace.

(3) The frame projection in the rear may be an uninclosed porch, an addition to a bedroom, an additional room, or a bathroom-known as "swinging bath." The second-floor joists are set lengthwise of the building and extended through the rear wall, thus saving the construction of brickwork.

The most prevalent type of dwelling in Baltimore is a 14-foot front, six-room, bath-and-cellar house. Such houses are two stories in height. They are set close upon the sidewalk in front, and have a small back yard. While these houses give the impresion of comfort and respectability, and are sufficiently well lighted and rentilated to meet all sanitary requirements, construction has been reduced to a remarkable degree of cheapness. Outside walls and party walls are 9 inches in thickness; the interior trimming woodwork-doors, door frames, stairways, etc. - are as light as possible; no moldings, beadings, or other millwgrk are used when flat surfaces may be used instead. The floors appear to be laid with low-grade material. Furnace, range, and bath fixtures are cheap and do not appear very durable. The existing system of surface drainage, only now giving place to a serrer system under construction at great cost, malkes it necessary to use privy vaults, hence the water-closet is almost always placed in the back yard, the only bathroom fixture being the tub.

Such houses as these are built for sale, as a rule, and only the house itself may be purchased. The ground-rent system prevails in Baltimore and few owners of cheap houses own the ground upon which they stand. The sale price of houses such as described above is $\$ 800$ to $\$ 1,000$; the ground rent being about $\$ 36$ per year. It is thought that it would not be profitable to build houses of this grade for renting purposes, as the repair account would inevitably be very great.

Houses of this type, however, may be rented and bring $\$ 12$ to $\$ 15$ per month, the customary rent being $\$ 13$.

Thus in Baltimore, a six-room house, improved with bathroom, with hot and cold water, range and kitchen sink with hot and cold water, hot-air furnace, cement cellar, papered walls. gas and gas fixtures, and electric call bell-and, indispensable item, white marble steps-may be found without difficulty and rented for $\$ 13$. This type of house in Washington brings $\$ 22.50$; here it is no more sanitary nor comfortable, but it is decidedly better constructed. and the 
addition of bay windows, peaked roof, or tower, in front, hardwood mantels, and embellishments of millwork, add to the cost, and must be paid for in rent, but do not add to the hygienic quality of the habitation. The Washington dwelling will be habitable, however, long after the Baltimore house has fallen into decay.

The above-described type is the prevailing kind of dwelling now being erected. In alleys and minor streets, however, large numbers

\section{Fig.24.}
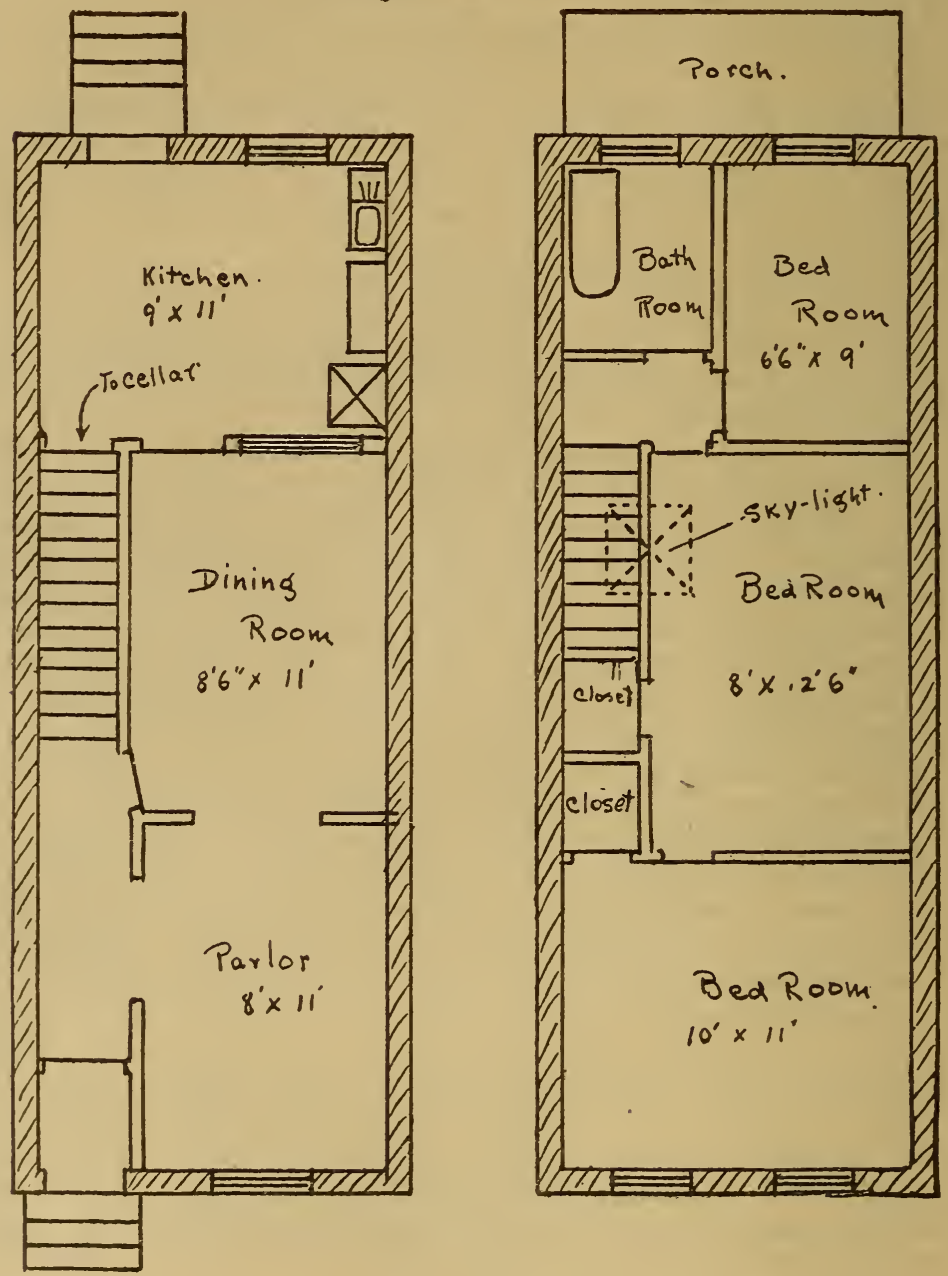

of four-room dwellings may be found which appear to have been constructed some years ago. Such houses vary in the improvements provided; some were found without gas supply, and without separate bathroom, but with a kitchen sink and cold-water supply, and a bath tub in a bedroom upstairs. The rooms were papered; there was a cellar, and back yard, where the closet was placed. The tenant provided all the necessary stoves. Such drellings rent for $\$ 7$ per 



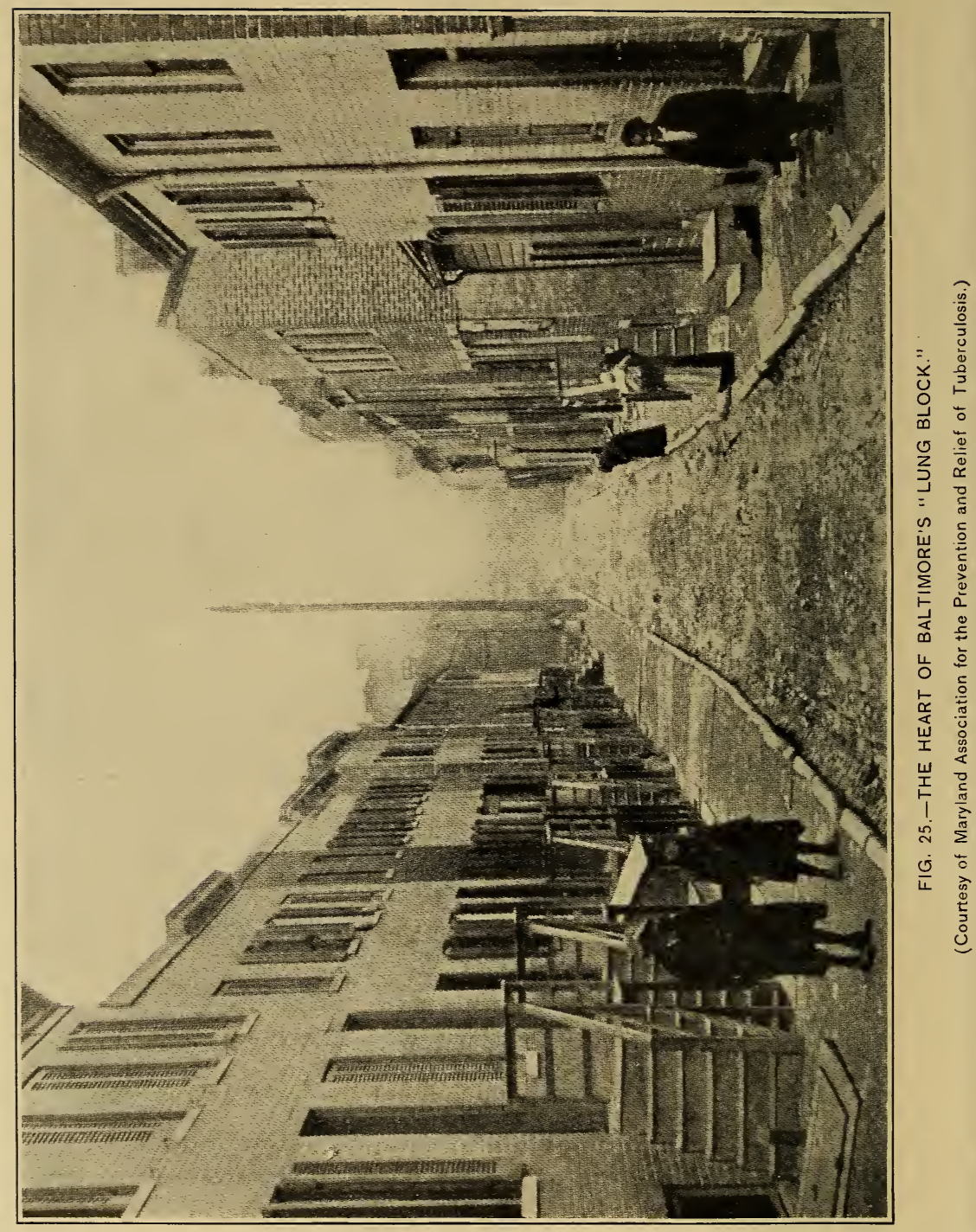


month; the owner paying for ground rent $\$ 24$ per year, taxes $\$ 12$, and water rent $\$ 2.50$. In another and somewhat better location, slightly larger houses of the same type were found renting for $\$ 9$; while on the opposite side of this same street were excellent four-room drellings, provided with the "swinging bath" described above, and with a range for supplying hot water, which were rented for $\$ 10$.

All of the dwellings spoken of were occupied by white tenants. There is no building of new drellings for colored people in Baltimore; they occupy dwellings abandoned in the march to more fashionable or newer residence districts. In a section of Baltimore occupied chiefly by negroes (Druid Hill avenue and cross streets and alleys opening upon it) the rents were found to be comparatively higher. On the larger streets, the 8, 10, or 12 room hou'ses were occupied by very respectable and well-to-do colored people, who paid from $\$ 25$ to $\$ 35$ in rent. The "room to rent" sign was frequently seen, and it is thought that there may be overcrowding here. In the minor streets and alleys opening upon Druid Hill avenue are very many houses of one type, all occupied by negroes. These are two and three stories in height, all with basements and all two rooms deep. Occasionally such houses have running water in the kitchen, but usually there is only a hydrant in the yard. An eight-room house of this type (two rooms in the basement) rents for $\$ 15$; a five-room house (one room in basement) rents for $\$ 12$.

There is also an old type of four and five room and cellar house to be seen in the alleys, most dark, dismal, and insanitary, which rents by the week at from $\$ 1.50$ to $\$ 2.50$; but even these houses seemed better structurally than the old frame houses on our main streets which bring from $\$ 12$ to $\$ 15$. The Baltimore house of this type is, however, so small and situated in such narrow alleys that area congestion must enter into the equation.

In general it may be said that in Baltimore housing of the negroes is a problem awaiting solution; the homes available for the least resourceful are unfit in many respects, and there is no building of new dwellings for colored people.

For white tenants rents are very much lower than in Washington, as has been pointed out. Also the supply of small dwellings is large and constantly increasing. But the six-room dwellings, now the popular type, seem to be occupied by the skilled-laborer class. The fourroom minor street house is available for unskilled laborers; but this type is no longer built, because the six-room house can be constructed for a trifling increase of cost, and the rentals can be disproportionately increased.

For the present people of small resources are able to secure comfortable and sanitary homes very much more reasonably in Baltimore than in Washington, and superficially it would appear that if construction could be carried out as cheaply here, the erection of the Baltimore type of dwelling should be in every way encouraged. But it is much to be feared that Baltimore will find future embarrassment from the early decay of these houses, or that the large expense to keep them in proper repair will soon teach builders that they are a poor investment, and the laborers who buy them will find that they have bought very dearly after all.

$$
\text { S. Doc. } 599,60-2-5
$$


"Philadelphia has been called 'the city of homes,' and it is that," said an official in the building inspector's office. As in Baltimore, the northeastern section of Philadelphia, in the textile district, where are large manufactories of woolens, silks, hosiery, and carpets, is the seat of constant and extensive building operations.

The best type of cheap dwelling is the two-story, porch-front house. This is the dwelling which at present is most popular and most frequently seen. The cost of erecting this type of dwelling varies in different portions of the city. In West Philadelphia very large numbers of such houses have been erected at such cost as will permit of rentals of from $\$ 18$ to $\$ 25$ per month. These dwellings shelter skilled mechanics, clerks, tradesmen, and the like, and so do not concern this inquiry.

In the "textile district," above alluded to, the two-story, porchfront house shelters mill operatives and skilled laborers of that type. In this locality the cost of construction is such that the maximum rental found was $\$ 16$; several houses in one such block were vacant,
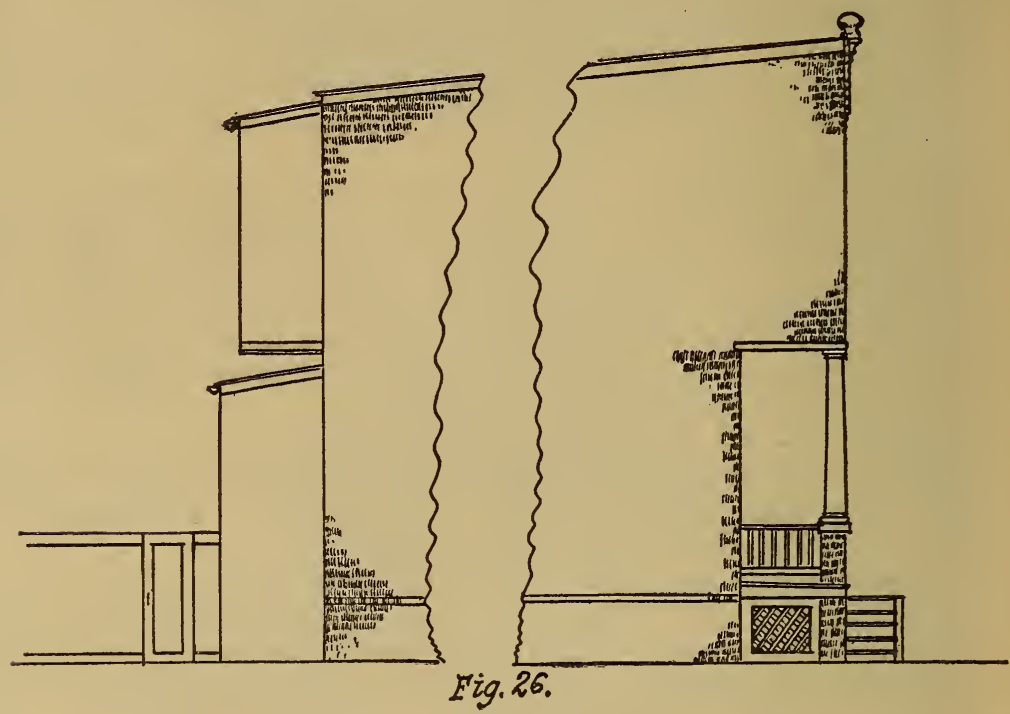

and a resident stated that the rental formerly asked was $\$ 18$; that it was found necessary to make a reduction to $\$ 16$ to keep tenants, and that a further reduction to $\$ 15$ would probably have to be made to attract new tenants. These houses are most attractive in appearance, convenient and sanitary in design, and apparently substantial in construction. It may be well to mention here a feature of construction almost universal in its application to small dwellings, namely, a frame overhang from the second story and a frame shed in the rear of the ground floor. The frame overhang in six-room houses constitutes one-half of a bedroom; in four-room houses, later to be described, it constitutes the bathroom-entirely similar to the "swing bath" of the Baltimore houses. The frame shed is used as a summer kitchen, or in many instances stationary laundry tubs are placed therein. Figure 26 illustrates this construction. The brick party wall is extended in the rear so as to afford fire protection between adjacent frame overhangs or sheds. 
furnace; the walls are all nicely papered; the parlor, reception hall, and dining room have pleasing mantels; the gas fixtures are good, and include a drop light in the dining room; and the front bedroom, in addition to a closet, is provided with a wardrobe built in the wall, with hardwood doors, fitted with mirrors, and two drawers underneath. Figure 27 gives the floor plan and figure 28 the elevation of this type of dwelling. Such houses may be bought for $\$ 2.600-$ $\$ 200$ cash, balance in monthly installments, amount not ascertained, probably mutually agreeable to purchaser and vender.

Another type not so frequently seen was found on a neighboring street; the floor plan of these was not essentially different, but there was no reception hall. The internal improvements were less expensive, and some space was lost by reason of the encroachment of the

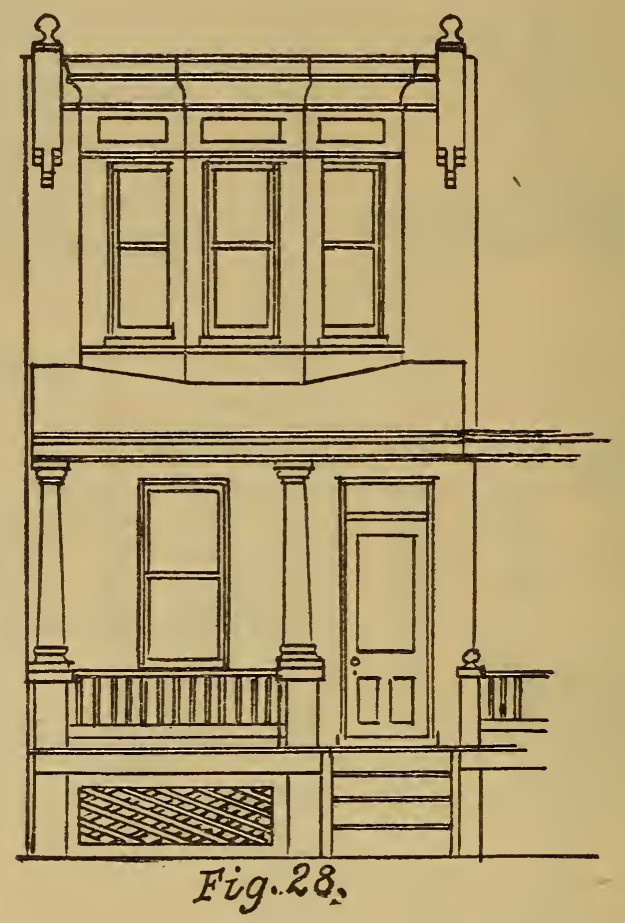

porch upon the first floor as shown in figure 26. These dwellings rented for $\$ 15$ and could be bought for from $\$ 1,900$ to $\$ 2,100$, easy terms. The heat for these also was furnished by a hot-air furnace, or in Philadelphia parlance, "a heater."

The cheapest type of dwelling recently erected is a four-room, bath, and shed house, as shown in figure 29, copied from a set of plans obtained from the building inspector's office. Such houses rent for from $\$ 10$ to $\$ 13$, and are papered, have gas supply, range, and hot and cold water supply, cellar and cemented yard.

Since the house illustrated in figure 29 can be converted into a five or six room dwelling, by constructing the shed of brick. and continuing these walls to the roof, at the additional expense of only $\$ 150$ or $\$ 200$, and as the resulting dwelling commands $\$ 15$, instead of $\$ 10$ 
The small alleyway, cemented so as to make a slightly concave gutter drained at intervals, and the cement-covered yards appeared to be kept in the perfection of cleanliness.

The impression made by the survey was that homes are prorided in Philadelphia in abundance and at very reasonable rentals; that sanitary, comfortable dwellings may be had there in large numbers at rentals which we consider available for unskilled laborers; but that, so far as this investigation went, this class of humanity has not
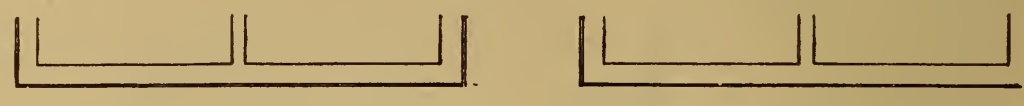

M.n..

5treat
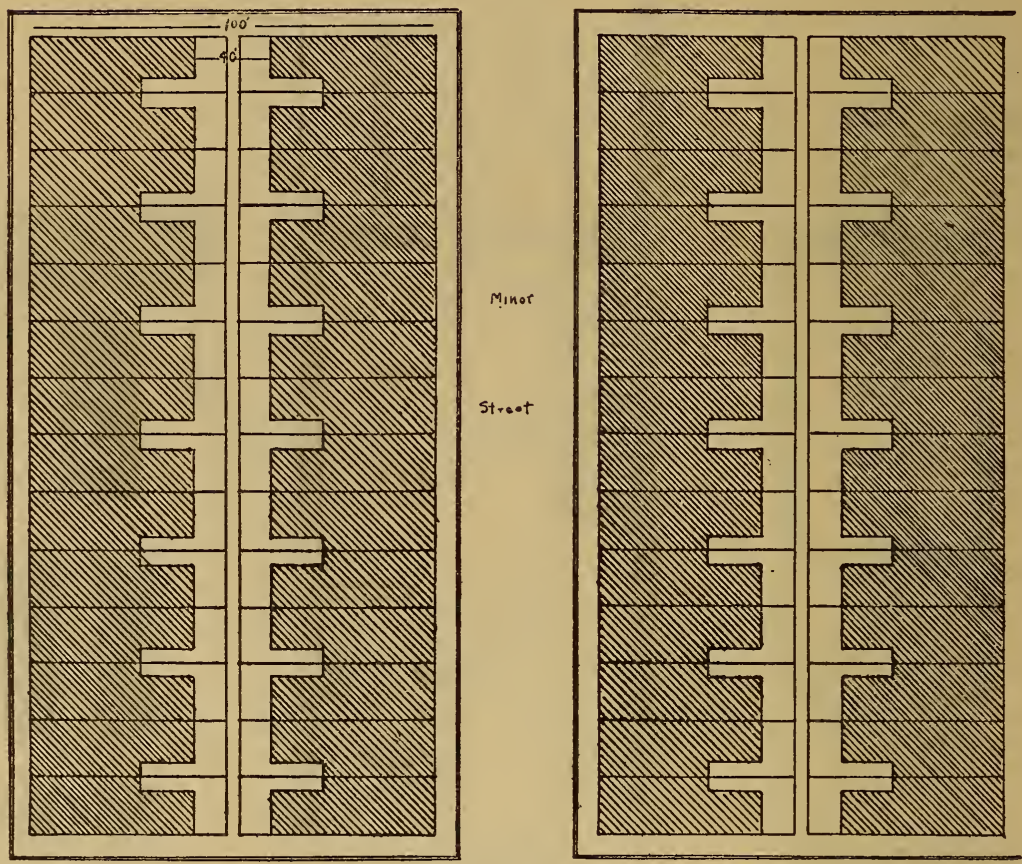

FIG. 30.

availed itself of these dwellings, but, as everywhere else, has sought and remained content with minimum rentals and the accompanying congestion and squalor.

V. THE HOUSING PROBLEM IN ENGLAND AND GERMANY.

While the problems connected with the housing of the laboring classes are somewhat different in different countries and in different parts of the same country, there are many points in common, and in considering these problems we will do well to take advantage of the experience gained abroad. In England, especially, this subject has occupied the attention of philanthropists and of legislators for many years. During the past fifty years no less than 28 acts of 
Parliament have been passed dealing with the housing question and for the last ten or twenty years a strenuous agitation in favor of housing reform has been steadily growing.

In the practical work of eradicating insanitary houses and providing sanitary houses for their occupants two plans of procedure have been adopted, as described below by Nettlefold: ${ }^{a}$

Under part 1 the local authority mist satisfy itself that the sanitary defects of any area can not be effectually remedied otherwise than by making an improvement scheme for the rearrangement and reconstruction of the streets and houses on the area. This entails heavy expense and great delay in the preparation of exhaustive reports and minute detailed maps and estimates. The schene has to be advertised several weeks; notice has to be given every owner and an answer obtained; the local gorernment board has to be petitioned, and names of dissenting owners have to be given. The local government board has to hold an inquiry to ascertain the correctness and sufficiency of the scheme and to hear objectious. An act of Parliament has to be obtained to confirm the order of the local government board and either House of Parliameut may refer the scheme to a committee of the House. The costs of the local authority in promoting the scheme, the costs of the local government board itself, and also the costs of any owners opposing the scheme may be charged to the local authority by the local government board.

In addition to all this, there is a probable obligation to provide accommodation in a congested district for a working-class population equal in number to that displaced. It is the almost invariable experience of these schemes that the population displaced does not return to the new houses, but finds accommodations elsewhere; while other's move in who would be much wiser to live outside the town.

All the land and buildings have to be bought up by the local authority on the terms of compulsory purchase, which entails paying anything from 10 per cent to 50 per cent above the real value. All the old buildings must come down, good and bad together. Very often manufactories and public houses have to be purchased and demolished. The worse the neighborhood the more the ratepayers have to pay for the public houses, while the demolition of the manufactories deprives the inhabitants of their means of livelihood. Most schemes under part 1 entail the construction by the corporation of new roads, new sewers, and new water mains, on the top of which comes the rebuilding of the houses, some of which-indeed, often many of which-were quite satisfactory.

The expenditure incurred is very large for the result obtained, but that is not the worst feature. Bad landlords are rewarded for neglecting their houses, while good landlords are often penalized.

Tnder part 2 the procedure is by no means as easy as it might be, but it is far simpler, and less expensive than part 1.

It is the duty of the medical officer of health to draw the attention of the local authority to any houses in his district that, in his opinion, are unfit for human habitation. The local authority considers the representation of the medical officer of health, and if they consider it to be justified, then an order is made that notices shall be served on the owners to repair their houses at their own expense, and not as under part 1, at the expense of the ratepayers. If the necessary repairs are not executed within a reasonable time, then the magistrates are asked to make a closing order, on the ground that the houses are unfit for human habitation. The object of applying for a closing order is to enable the local authority to prevent the owner from receiving rents for houses that are unfit to live in. If the closing order is granted, then the houses remain empty until the necessary repairs are executed, or until the time has elapsed (three months), which the act allows the owner for doing what is required. If at the end of that time the owner has done nothing, then the case is again considered by the local authority, and if circumstances justify such a course, a resolution is passed by them deeming it adrisable that the houses shall be demolished. The owner is advised of the passing of this resolution and invited to attend a statutory meeting of those who have passed it, and state his reasons why the house should not be demolished. If the local a uthorities are satisfied with the reasons given, then the houses are allowed to remain standing. If

a "Practical Housing," by J. S. Nettlefold. Published by the Garden City Press, Letchworth, England. Price, 1s. 
they are not satisfied, a demolition order is made, against which the owner has a right of appeal to quarter sessions.

In my experience, which is now fairly long, this right of appeal has never been exercised, owing, perhaps, to the fact that demolition is not resorted to unless there is a strong ground for doing so.

If a property owner shows the slightest inclination to meet the authorities, it is always advisable to exercise patience and give him a chance of carrying out his promises.

The object of part 2 is to insure that houses that are unfit for human habitation shall be made fit to live in or demolished. It is generally impossible to achieve this end without removing one or more of the adjacent buildings, because the most insanitary houses of all are generally found in thickly built neighborhoods.

The necessity for the removal of obstructive buildings is specially provided for in part 2, section 38, of the 1890 act, which empowers local authorities to pay compensation in these cases. This power, carefully used with due consideration for the interests of the ratepayers and sympathetic consideration of the wishes of property owners, not only facilitates the work of slum reform, it also makes it possible to insure thorough repair in place of the slum patching which is only too prevalent.

By dealing with individual houses in this gradual manner only bad property is repaired or demolished, while what is sound is left standing, thereby avoiding one of the causes of great waste under part 1 , and also all danger of creating a house famine.

The procedure under part 2 is not only far less expensive than under part 1 , it is also fairer, because it puts the cost of repairing insanitary houses on the right shoulders and makes the neglect of small house property unprofitable. There are some who would amend part 1 in order to make it more workable, and no doubt the procedure might be improved in detail; but my contention is that part 1 is thoroughly unsound in principle, whereas part 2 is fair in principle, besides being efficient, and in practice very cheap.

My experience is that part 2, administered with vigor and discretion, is capable of doing what is required without putting any serious burden on the ratepayers, and it should be much more freely used. One thing, at any rate, is quite clear, part 1 has not failed for want of being tried.

It is probable that far better results would be obtained if part 2 were adopted all over the country instead of part 1.

To avoid confusion I will take only those houses provided under part 1, the cost of which is clearly given; 10,805 houses have been dealt with; $£ 4,202,-$ 655 has been spent; 54,030 persons rehoused, giving an average of $£ 77$ 15s. per person.

The cost per head of rehousing varies from $£ 40$ 19s, in some places to $£ 197$ 4 s. in others.

Very many more than 10,805 houses have been dealt with under part 1 , and of course a great deal more money spent, but the data is not sufficiently clear and reliable to justify their inclusion in this calculation and comparison.

The cost per head of rehousing under part 1 averages $£ 7715 \mathrm{~s}$. all over the country, but let us for the purposes of this comparison take it at $£ 50$.

The cost of replacing hovels with good cheap houses under part 2 works out in Liverpool at $f 7$ per house. Taking the usual arerage of five persons to a house, this works out at $£ 1$ 8s. per head. The cost per head in Birmingham of similar work under part 2 comes to $£ 14 \mathrm{~s}$. $3 \mathrm{~d}$.

As Liverpool gives the best example of work done under part 1, a short description of their Hornby street scheme (for which I am indebted to Mr. F. T. Turton), will be interesting, and may be compared with what has been done in Birmingham, where part 2 has been used to a greater extent than anywhere else.

When the Hornby street area was scheduled as an " unhealthy area " in 1902, under the housing of the working classes act, 1890, the number of insanitary houses which it contained was 511, in addition to which there were 23 sanitary houses, making a total of 534, representing a population of 2,431 .

The insanitary houses were of the back to the back type, situated in narrow and ill-ventilated courts, each court containing from 10 to 12 houses. The sanitary arrangements were very defective, in many cases one convenience being used by the occupants of five or six houses.

The total contents of the area were 27,600 square yards, and the freehold of the land and buildings was acquired at a total cost of $£ 56,000$, or $£ 2$ per yard; 
but it must be mentioned that five licensed public houses were included in the area. Excluding these public houses the cost of acquiring the area represents 33s. per square yard.

Hornby street is 36 feet wide, but by setting the buildings back from the existing building line for a considerable length of the street, the width between the main line of the buildings is now about 70 feet.

The frontage to the dwellings in Hornby street have been laid out as grass plots flanked with a low wrought-iron ornamental railing, and here-and there strong seats are provided for the use of the tenants only, while at the rear of all the buildings separate yards have been avoided and the whole space thus a vailable finished so as to form large playgrounds for the children, it being expected by this means the children may have room to play their games away from the dangers of street traffic.

The whole of the area comprises, as preriously stated, a total of 27,600 square yards. Of this amount 2,019 square yards have been 'voluntarily given up for street widening and 3,200 square yards allocated for the provision of grass plots in front of the dwellings.

In addition the scheme provides for a recreation ground of 1,633 square yards in the center of the area, surrounded on three sides by shrubberies 6 feet wide and provided with gymnastic apparatus and a sand pit about 40 feet by 20 feet. A large shelter is placed in one corner of the ground and a drinking fountain near by for the use of the children.

The new dwellings comprise 23 blocks, containing 453 tenements, which it is estimated will accommodate 2,446 persons. There are 50 four-roomed, 211 three-roomed, 173 two-roomed, and 9 one-roomed dwellings, together with a superintendent's house, office, and stores, seven shops, a coal yard, and a recreation ground of about a third of an acre in extent.

The buildings, with the exception of the superintendent's house, are three stories in height, the height from floor to floor being, generally speaking, 9 feet 10 inches.

The construction of the buildings is of a fireproof character, the subfloors consisting of rolled-steel joists spaced about 3 feet apart and embedded all a round in a thickness of 7 inches of coke breeze concrete.

In the first place, a portion of the area was demolished which contained a population of 724 persons, and on the site so cleared new dwellings were erected to accommodate 768 persons.

A second portion was then demolished and the persons dispossessed, riz, 822, had the opportunity of inhabiting the new dwellings erected on the first portion rebuilt. In like manner a third portion was cleared, from which 885 persons were dispossessed, and were accommodated in the new dwellings erected on the site of the second portion cleared. The new dwellings to be erected on the third portion are in course of erection at the present time.

As is generally known, a special feature of the work in Liverpool is that the corporation will only accept as tenants those persons who have been dispossessed through the demolition of insanitary property; and in this connection it may be mentioned that when the first portion of the Hornby street area was demolished, 71 per cent of the persons dispossessed became tenants of the corporation in their rarious blocks of dwellings in the ricinity.

When the portion at present in course of erection is completed the disposition and rents of the whole area will be as under, viz, ground floor, 15 four-roomed tenements at $5 \mathrm{~s}$. 3d. per week each; 72 three-roomed tenements at $4 \mathrm{~s}$. $6 \mathrm{~d}$. per week each; 61 two-roomed tenements at $3 \mathrm{~s} .6 \mathrm{~d}$. per week each; three one-roomed tenements at $2 \mathrm{~s}$. $6 \mathrm{~d}$. per week each, and six shops with tenements, one let at $14 \mathrm{~s}$., one at $12 \mathrm{~s}$. $6 \mathrm{~d}$., and four at $12 \mathrm{~s}$., respectively, per week, and coal yard at $7 \mathrm{~s}$. $6 \mathrm{~d}$. weekly. First floor, 16 four-roomed tenements at $5 \mathrm{~s}$. per week each; 76 threeroomed tenements at $4 \mathrm{~s}$. $3 \mathrm{~d}$. per week each; 56 two-roomed tenements at $3 \mathrm{~s}$. per week each; 5 one-roomed tenements at $2 \mathrm{~s}$. per week each. Second floor, 18 four-roomed tenements at $4 \mathrm{~s}$. $6 \mathrm{~d}$. per week each; 72 three-roomed tenements at $4 \mathrm{~s}$. per week each; 48 two-roomed tenements at $2 \mathrm{~s}$. $9 \mathrm{~d}$. per week each; 1 oneroomed tenement at $1 \mathrm{~s} .9 \mathrm{~d}$. per week each.

Total gross rental per week, $\mathfrak{1} 899 \mathrm{~s} .6 \mathrm{~d}$.

Total gross rental per annum, $£ 4,65214 \mathrm{~s}$.

When the portion of the buildings at present in course of erection is completed the total cost of the dwellings on the whole of the area will be about $£ 80,786$, to which must be added $£ 56,000$, the total cost of the land including parliamentary and general expenses, which makes a total expeuditure of 
$£ 136,786$, without counting a few odd extras which, I think, may fairly be omitted. The tenements provided are: 49 with 4 rooms; 220 with 3 rooms; 165 with 2 rooms; 9 with 1 room; total, 443.

These 443 tenements are allowed by the local gorernment board to provide accommodations for 2,446 persons, $£ 138,786$ total expenditure divided by 2,446 gires an expenditure of just £56 per head.

For building alone the cost represents 5.TTd. per cubic foot, but taking into account the formation of back streets, passages, and open spaces, it represents 6.06d. per cubic foot, or $£ 66$ per room.

In granting the loans necessary for carrying out of this work the local government board allowed eighty sears for the repayment of the loan for the purchase of the land, and sixty years for the repayment of the loan in respect of the buildings.

The rents charged are as high as the tenants can afford to pay, and approximate very nearly to the rents paid by them in their former insanitary habitations.

The porerty of the tenants generally can be imagined when it is stated that several thousand families in this city subsist on an average of less than $10 \mathrm{~s}$. per week, and a greater number on less than $15 \mathrm{~s}$. per week.

The improrement in the condition of the tenants in their new surroundings is very noticeable. The cleanliness of their houses has been greatly improred, and in the general conditions of the neighborhood there is a distinct change for the better.

That these and other dwellings provided by the corporation under similar conditions are appreciated by the tenants is best shown by the fact that there are rarely any to be let and that during last vear 96 per cent of the rent actually due was collected.

Those who consider municipal house building the only satisfactory remedy object to the Birmingham work, because the houses dealt with are not all "brought up to the present by-laws standards." In my opinion what is done in Birmingham under part 2 is much better than the barrack dwellings built elsewhere under part 1 ; but this question can not be settled by argument. Those interested are cordially invited to come and see for themselves.

Another objection is the rise in rents consequent on repairs. In Birmingham the arerage rise has been 7 d. per week. (See Doctor Robertson's report, 1905.)

Under part 1, when there is no charge on the rates direct or indirect, overt or corert (such as taking the land at "housing ralue" instead of at its real value, etc.), the rise in rents is nearer $2 \mathrm{~s} .6 \mathrm{~d}$. than $7 \mathrm{~d}$., and, in consequence, rery few of the tenants turned out of the old houses were able to go into the new ones, except in the special case of Liverpool, where this point has been particularly watched. Under part 1, therefore, slum reform is either a considerable charge on the rates or else the rise in rents is prohibitive to the old tenants.

Under part 2, on the other hand, tenants hare often been asked about this arerage rise of $7 \mathrm{~d}$. per week, and their general reply is that this small rise in rent for a "house" instead of a "hovel" pass them very well in the long run. They hare not the same temptation to spend the erening in the public house.

No thoughtful man will adrocate the letting of houses below their economic rent by means of subsidies from the rates, in one form or another, either orert or corert.

Wages follow rents, and therefore that policy would only result in providing capitalists with cheap labor at the expense of the general body of ratepayers. Capitalists as a body are quite able to take care of themselres without any outside assistance, and there is no reason for providing them with cheap labor at the expense of the general body of ratepasers.

The object of housing reformers should be to level up, not to level down; we should endearor to secure the best possible housing accommodations within the means of the people and not to reduce rents by cutting quality or manipulating the local rates.

At the same time it must not be forgotten that if house rents are too high, owing to bad organization or bad management, then either we shall not get the people we want to help into the houses provided, or if they do go in they will overcrowd them with lodgers in order to pay the rent.

Some may think that municipal inspection ought to prevent this evil; but practical men know that no amount of inspection will correct the results of a policy that is economically unsound. The driving forces behind unsound 
economic conditions are far two strong to be affected to an appreciable degree by any inspectoral arrangements, especially in this country, where we set so much store by the liberty of the subject.

The following comparison of housing conditions in England and in Germany is made in the Report of the Housing Committee of the City of Birmingham (1906):

VISIT TO GERMANY.

Your committee submit the following observations upon the general impressions of the deputation:

\section{HOUSE ACCOMMODATION.}

Ererywhere the deputation found the dwelling houses of the artisan classes were in a beantifully clean condition and that house pride appeared to be more evident than in England. The deputation asked to be taken to the poorest parts of the cities and towns, but in no case did they see any of the conditions of filth and dirt in the houses nor of dirty, ragged children in the streets that one meets in the lon-class districts in Birmingham and other large English cities. Ererywhere these conditions of cleanliness of houses and children and clean, healthy people were in some measure due to the great care and thrift displayed by the German workingman.

The houses themselves appeared to the deputation to be incomparably inferior to those in English towns, when the amount of accommodation and the lighting, ventilation, and air space surrounding the house is taken into consideration. Everrwhere in the tomns the "flat" system is prevalent, producing imposing buildings on either side of relatirely wide streets. In this respect the German towns resemble very closely most of the Scotch towns, in many of which the buildings are as high and the streets as wide and as well laid out and handsome as those in German towns.

Just as it is impossible to judge of the conditions in prorincial towns in England from those existing in the metropolis, so those existing in the German metropolis differ from those in the provincial towns. While this is so, ererywhere it was evident that the number of rooms per family is considerably less than in our English towns.

General arrangement of the buildings.-The effect of town planning in the newer parts of the German towns risited was distinctly in the direction of insuring the erection of suburbs which are pleasant to live in and convenient of access. It appeared to hare the effect of preventing straggling suburbs, which are difficult to provide with means of transit on account of their sparse population and which requires costly roads to be made without much use being made of them for many rears. Immediately the derelopment of the extension plan is commenced it becomes possible to contemporaneously derelop tramway and railway systems. In this way it appeared to be beneficial to owners of estates, because they did not require to spend money in laying out until just before the time the whole of the estate would be dereloped.

General healthiness. - The statistics of the German towns are scarcely comparable with those in this country, because customs differ so much in the two countries and there are so many influences at work other than housing conditions in producing high mortality. Speaking generally, the mortality rates for the last five years for which figures are available are as follows:

\begin{tabular}{|c|c|c|c|}
\hline The United Kingdom. & & The German Empire. & \\
\hline 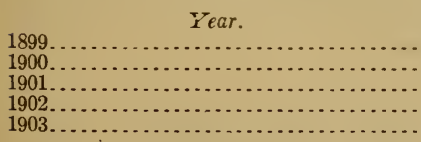 & $\begin{array}{r}\text { Death rate. } \\
18.2 \\
18.4 \\
17.1 \\
16.5 \\
15.8\end{array}$ & 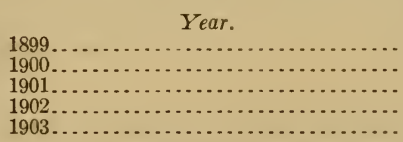 & $\begin{array}{r}\text { Death rate. } \\
21.5 \\
22.1 \\
20.7 \\
19.5 \\
20.0\end{array}$ \\
\hline
\end{tabular}


As a rule most of the German towns show higher death rates than corresponding towns in England. The mortality rates from certain diseases, such as typhoid ferer and diphtheria, are also considerably higher.

There is a high mortality among infants, amounting to 207 per 1,000 born in the year 1901, as compared with 151 in England during the same year.

Notes on the housing question.-About the year 1900 the city board of Berlin, like all boards and gorernments in Germany, experienced the disagreeable fact that small and cheap lodgings had become extremely rare. The prices for small lodgings were raised to a height that made it almost impossible for workmen, subaltern officials, small traders, etc., to pay the rent. The disinclination of the private building speculators to provide for the sudden want had different social causes which may be known to you sufficiently, so that we may pass over them here. Only the measures taken by the Berlin city board shall be discussed. We shall also not consider what has been done for the homeless poor by public institutions (Offentliche Armenpflege). The municipal and provincial magistrates in Germany are obliged to provide for the poor.

Until it was proved that private organizations and private men were not able to satisfy the present want for lodgings, the administration themsel res could not begin to build at their own risk. The support consisted, as is usual here, in the grant of mortgaged credit. But it needed special care to prevent the possibility of single private men having the profit of the facilitated credit, in order that the advantage be not lost to the public. During the last rears three unions have received such a loan of 500,000 marks $(£ 25,000)$ bearing interest at about 3 per cent, and due for repayment in a period of about ninety years. This rate of interest is in our country rather low, especially in consideration of the fact that other mortgages have the preference. In exchange the unions are obliged to present their projects of building to the city council, to finish the buildings in a fixed time, and to subject themselves to a continual control by the administration. The rents have to be fixed in such a way that they cover the costs of the interests and the maintenance of the buildings. The surplus must not be used for accumulating capital, but for making the rents of lodgings cheaper, for improving the lodgings, and for sanitary and beneficiary purposes. The unions must inform the city council of their resolutions; the balance sheet must be approved of, the city reserving the right to acquire the property when the union is dissolved, also a right of preemption.

RENTS AND WAGES.

The arerage rent in Berlin of workingnien's dwellings for two rooms and a kitchen in a flat is from $20 \mathrm{~s}$. to $24 \mathrm{~s}$. per month. Other rents are: One-roomed tenement at back, $3 \mathrm{~s}$. per week; two-roomed tenement at back, 4s. 6d. per week; three rooms in front, 8 s. pel week.

The water rate is included in the rent, but gas and rates are excluded.

No rate is paid on a dwelling house. The ratepayer pass a rate to the council equal to his income tax paid to the State, from which it follows that workmen who are exempt from income tax to the State are also exempt from the payment of rates to the council.

The average wages of the unskilled laboring class in Berlin are about $\mathfrak{f 5}$ a month.

\section{SUPPORTING PRIVATE ENTERPRISES.}

The town of Stuttgart is endearoring to assist as much as possible private building enterprises that are useful to the community. Lately it supported the Society for the Welfare of the $T$ orking Classes by a loan of $4,000,000$ marks at a low rate of interest ( 3 per cent), when this society decided to pull down and rebuild a considerable part of the old town. As a rule it endeavors to promote building enterprises of general utility without discouraging private building enterprises.

VI. THE HOUSE FAMINE.

In speaking of a "house famine" in the national capital we refer entirely to houses for the poorer classes of the community. The 
population of the city is rapidly increasing and houses are being built in sufficient numbers for the accommodation of those who are able to pay monthly rentals of $\$ 25$ and upward. Very many new brick houses containing five or six rooms are being built in various parts of Washington, and especially in proximity to street-car lines on the outer edge of the ever-expanding city. A considerable proportion of these are sold on easy terms to clerks, skilled mechanics, etc. They are as a rule attractive in appearance, well arranged, and provided with all modern sanitary conveniences. They are sold at prices ranging from $\$ 3,500$ to $\$ 5,000$ and rented at from $\$ 25$ to $\$ 40$ per month. But these houses are quite beyond the reach of day laborers, who can not afford to pay more than $\$ 8$ to $\$ 10$ a month. When they are compelled to pay more than this, they find it necessary to sublet one or more rooms. When the building of cheap frame shanties in the alleys of the city was unrestricted, the building of such houses was likely to keep pace with the demand, as they cold be readily rented at rates which would give a return of 10 per cent or more on the money invested. But under existing regulations no more house can be built within the alleys and no more frame houses can be built within the fire limits of the city. There has, therefore, been an almost complete arrest of building houses to be rented for $\$ 12$ or less per month. The house famine for this class of houses is also being accentuated by natural decay and the condemnation of insanitary houses. A law was enacted in May, 1906, establishing a board for the condemnation of insanitary dwellings, and up to June 30,1908 , this board had taken action upon 959 houses, of which 545 have been demolished and the rest are under notice for demolition or repair.

The condemnation of insanitary houses by the board of health then in existence was authorized by section 9 of an act of Congress approved February 21, 1871, which reads as follows:

SEction 9. That any dwelling house or building wherein people live or assemble which is deficient in rentilation, drainage, or other provisions essential to health, which has a leaky roof or is below grade, so as to render the walls thereof damp and the rooms unhealthy, or is decayed or filthy, and premises which are filthy and offensire are hereby declared nuisances injurious to health; and any person who shall create or maintain such nuisances, and who shall fail, after due notice from the board, to abate the same, shall, upon conviction, be fined not less than fire nor more than fifty dollars for every such offense.

Under this authority 389 dwellings were condemned in 1874 ; in 1875,694 houses were reported as unfit for human occupation and 198 were condemned; in 1876, 424 houses were reported and 371 condemned.

In his paper on "The history and development of the housing movement in the city of Washington, D. C. (1907)," Dr. George M. Kober says:

Unfortunately for the residents and the fair name of the city, the board of health was abolished and the office of the health officer created by an act of Congress approved June 11, 1878, and, most unfortunate of all, in the legalization of the health ordinances in $1 S S 0$ the section under which the health department acted in the condemnation of houses unfit for human occupation was omitted and the good work stopped.

It is shocking to know that twenty-six years ago it was possible for men with mean and selfish motives to arrest this battle for humanity, for higher standards 
of living, for improved sanitation of the national capital, and it is equally humiliating to contemplate that it required ten years of agitation to secure a legislative remedy to deal with this cancer as did the health department from 1872 to 1880 .

This battle against the slums does not concern a few well-meaning citizens alone; it is a question of vital importance to the health, not only of every permanent resident, but to the Chief Magistrate, his Cabinet, the foreign ministers, thousands of public officials, the members of the Senate and House of Representatires, and all citizens having business with Congress, besides the countless numbers of risitors who annually pay homage to the city of Washington.

It is evident that with an ever-increasing population and the decay and condemnation of existing houses now occupied by the poorer classes of the community the house famine will constantly become more acute, unless the construction of new houses for the unskilled laborers of the city can be stimulated in some way. In a subsequent chapter an account will be given of the efforts which have been made in this direction and suggestions will be offered with reference to practical measures for the relief of the situation. In the present chapter we shall give some precise data with reference to building operations in the city of Washington during the past five years, as regards houses costing less than $\$ 1,500$. As a matter of fact, an unskilled laborer who is married and seeks an independent home for his family is restricted in his selection to a house renting for $\$ 12$ or less per month. Taking the maximum figures, the yearly income to a landlord will be $\$ 144$ per annum. When we consider the cost of repairs, insurance, taxes, water rents, collection of rents, etc., it is safe to calculate that 10 per cent gross is about as low a figure as would tempt capital to build houses as an investment for this class of tenants.

This would mean that a house renting for $\$ 12$ per month should not cost more than $\$ 1,440$-including lot, sidewalks, charges for semer extension, and all incidental expenses. For a house renting at $\$ 10$ per month, the entire cost should not exceed $\$ 1,200$. The records of the building inspector's office show that the number of houses built during the past five years, the cost of which is stated to be $\$ 1,500$ or less. is only 91 . But the records of the building inspector only give the cost of construction, and to this must be added cost of lot, grading, sidewalks, sewer extension, and in some instances street improvements. It is therefore evident that the actual cost of construction should not greatly exceed $\$ 1,000$ if the house is to be rented for $\$ 12$ per month. But our investigations show that during the past five years only 7 houses have been built the cost of which is given at $\$ 1,000$ or less.

The following data compiled for the committee on building of model houses, by Dr. H. C. Macatee, will give more in detail the available information with reference to the construction of houses of low cost in the city of Washington during the past five years.

The tables here given are arranged for three types of dwellings: Brick, frame, and two-family apartment houses, the latter being almost without exception of brick.

The tabulation by geographical sections seemed most convenient, and in all the tables dwellings in the suburban communities are included in that geographical section in which they would lie if the dividing lines of the city were extended to the District line. 
TABLE 1.-Brick duellings costing $\$ 3,500$ and less erected during five years.

\begin{tabular}{|c|c|c|c|c|c|c|c|c|}
\hline Section. & $\begin{array}{l}\$ 3,000 \text { to } \\
\$ 3,500 \text {. }\end{array}$ & $\begin{array}{l}\$ 2,500 \text { to } \\
\$ 3,000 \text {. }\end{array}$ & $\begin{array}{l}\$ 2.000 \text { to } \\
\$ 2,500 \text {. }\end{array}$ & $\begin{array}{l}\$ 1,500 \text { to } \\
\$ 2,000 .\end{array}$ & $\begin{array}{l}\$ 1,000 \text { to } \\
\$ 1,500 \text {. }\end{array}$ & $\begin{array}{l}\$ 500 \text { to } \\
\$ 1,000 \text {. }\end{array}$ & $\begin{array}{l}\text { Under } \\
\$ 500 .\end{array}$ & Total. \\
\hline \multicolumn{9}{|l|}{ Year 1903.} \\
\hline Northwest.. & 41 & 132 & 64 & 36 & 5 & & & 278 \\
\hline $\begin{array}{l}\text { Northeast.. } \\
\text { Southeast.. }\end{array}$ & $\begin{array}{l}35 \\
35 \\
16\end{array}$ & $\begin{array}{l}26 \\
26 \\
12\end{array}$ & $\begin{array}{r}5 \\
5 \\
30\end{array}$ & $\begin{array}{l}5 \\
5\end{array}$ & $\begin{array}{r}3 \\
10\end{array}$ & & & $\begin{array}{l}10 \\
74 \\
73\end{array}$ \\
\hline \multicolumn{9}{|l|}{ Year 1904.} \\
\hline $\begin{array}{l}\text { Northwest.... } \\
\text { Southwest.... } \\
\text { Northeast.... }\end{array}$ & $\begin{array}{r}67 \\
1 \\
16\end{array}$ & $\begin{array}{r}21 \\
1 \\
43\end{array}$ & $\begin{array}{l}17 \\
30 \\
31\end{array}$ & $\begin{array}{r}8 \\
18 \\
11\end{array}$ & $\begin{array}{l}3 \\
5\end{array}$ & 5 & & $\begin{array}{r}116 \\
60 \\
101\end{array}$ \\
\hline Southeast......... & 25 & 7 & 52 & 20 & 10 & & & 114 \\
\hline \multicolumn{9}{|l|}{ Year 1905.} \\
\hline $\begin{array}{l}\text { Northwest. } \\
\text { South west. }\end{array}$ & $\begin{array}{r}149 \\
14\end{array}$ & $\begin{array}{r}26 \\
4\end{array}$ & $\begin{array}{l}22 \\
19\end{array}$ & $\begin{array}{r}7 \\
29\end{array}$ & 2 & & & $\begin{array}{r}206 \\
66\end{array}$ \\
\hline $\begin{array}{l}\text { Northeast.......... } \\
\text { Southeast........ }\end{array}$ & $\begin{array}{l}61 \\
22\end{array}$ & $\begin{array}{r}63 \\
4\end{array}$ & $\begin{array}{l}47 \\
29\end{array}$ & 30 & & & & $\begin{array}{r}171 \\
85\end{array}$ \\
\hline \multicolumn{9}{|l|}{ Year 1906.} \\
\hline $\begin{array}{l}\text { Northwest.. } \\
\text { Southwest.. }\end{array}$ & $\begin{array}{r}224 \\
3\end{array}$ & $\begin{array}{l}50 \\
11\end{array}$ & $\begin{array}{r}27 \\
7\end{array}$ & $\begin{array}{r}22 \\
9\end{array}$ & $\begin{array}{r}17 \\
2\end{array}$ & 1 & & $\begin{array}{r}341 \\
32\end{array}$ \\
\hline $\begin{array}{l}\text { Nort } \\
\text { Sout }\end{array}$ & $\begin{array}{l}6 \\
65 \\
36\end{array}$ & 17 & 16 & 2 & $\ldots$ & & & $\begin{array}{r}52 \\
100 \\
149\end{array}$ \\
\hline Year 190\% & & & & & 1 & $\cdots$ & & \\
\hline Year $190 \%$. & , & & & & & & & \\
\hline North west. & 145 & 30 & 66 & 61 & 9 & & & $\begin{array}{r}311 \\
33\end{array}$ \\
\hline $\begin{array}{l}\text { Southw } \\
\text { Northe }\end{array}$ & $\begin{array}{r}0 \\
42 \\
27\end{array}$ & $\begin{array}{l}15 \\
57\end{array}$ & $\begin{array}{r}5 \\
12\end{array}$ & 25 & $\begin{array}{l}0 \\
6 \\
-\end{array}$ & $\dddot{i}$ & & $\begin{array}{r}35 \\
143\end{array}$ \\
\hline Southea & 37 & 44 & 14 & 26 & 5 & & & \\
\hline $\begin{array}{c}\text { Total for five } \\
\text { years......... }\end{array}$ & 1,005 & 597 & 554 & 342 & 84 & 7 & & 2,589 \\
\hline
\end{tabular}

Brick single dwellings included in this table are nearly all situated within the city limits; a small minority have been built in the suburbs, but in most instances they have been built for private ownership. In Petworth, Brightwood Park, and Tacoma Park a number of brick dwellings have been erected which for character and rentals may with advantage be considered with the city dwellings.

Attention is directed to the fact that only 84 dwellings are listed as costing between $\$ 1,000$ and $\$ 1,500$, and 7 as costing under $\$ 1,000$. Of the 7 cheapest dwellings, 5 are located in the southwest and rent for $\$ 15.50$, while the remaining two have been erected in the suburbs for private ownership.

Inspection of 365 of the dwellings here tabulated, in all parts of the city, care being taken to include those of the lowest cost and least desirable location, revealed the fact that not one was found which could be rented for $\$ 12$, the unskilled laborer's maximum as estimated by General Sternberg. Two were found which were rented to colored tenants for $\$ 14$ and five to white tenants for $\$ 14.50$.

If dwellings renting up to $\$ 15$ be considered possible for the unskilled laborer, only seven out of the 2,589 brick dwellings erected in the past five years could be considered as in any sense relieving the house famine in this city. 
TWO-FAMILY APARTMEN'T HOUSES.

There has been considerable activity in the erection of two-family dwellings during the past five years, as the following table will show:

TABLE 2.-Tuo-family apartment houses erected during five years.

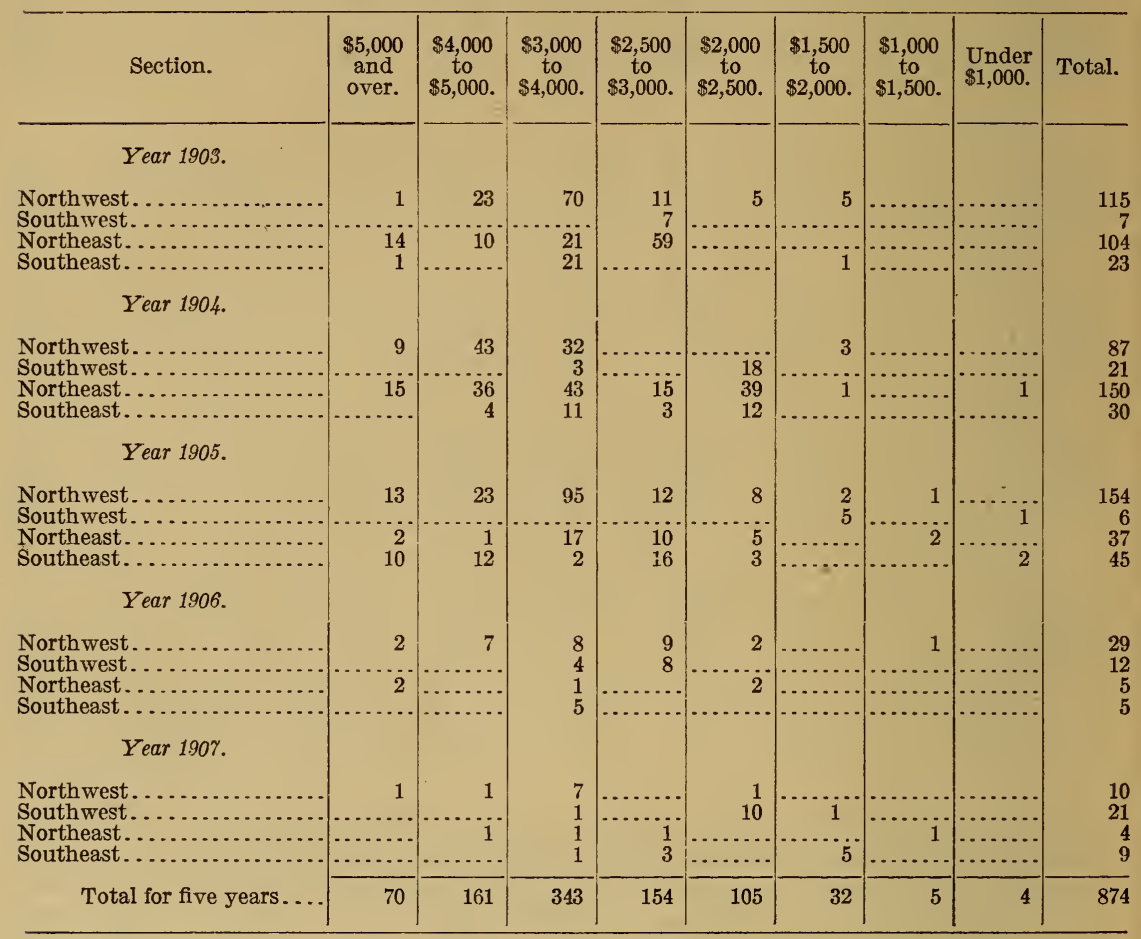

The 9 two-family dwellings listed as costing under $\$ 1,500$ do not properly belong in this table, as upon investigation they were found to be double frame dwellings located in the outskirts of the city and in the suburbs. There remain, then, 865 two-family apartment houses which have been erected between January 1, 1903, and December 31,1907 . Of these, 366 have been examined. Excluding houses erected by the Washington Sanitary Improvement Company and Sanitary Housing Company, 48 habitations may be rented for $\$ 15.50$, 68 for $\$ 14.50$, and 24 for $\$ 13$. No apartment house in this number cost above $\$ 2,800$; all cost $\$ 2,500$ and less except 21 far out on the edge of the city. It is fair to say, then, that not over 137 two-family apartment houses have been provided in which flats can be rented for approximately $\$ 15$. These houses would relieve 274 families of the house famine, if it be allowed that the people suffering from the famine could pay up to $\$ 15$ for rent; as a matter of fact, however, 22 of the flat dwellings investigated fall within the limits of cost of the 137 above mentioned, but rent as high as $\$ 21.50$ for four-room flats. This fact at once reduces the number of flats available for $\$ 15$ or less to 230 , and there can be no doubt that if all the houses erected were investigated the reduction would be still greater. 
Reference to the table will reveal the further fact that there has been a steady decline in the erection of such dwellings during the past three years, the high-water mark having been reached in 1904.

FRAME DWELLINGS.

TABLE 3.-Frame dwellings costing $\$ 3,500$ and less erected during five years.

\begin{tabular}{|c|c|c|c|c|c|c|c|c|}
\hline Section. & $\begin{array}{l}\$ 3,000 \\
\text { to } \\
\$ 3,500\end{array}$ & $\begin{array}{c}\$ 2,500 \\
\text { to } \\
\$ 3,000 .\end{array}$ & $\begin{array}{c}\$ 2,000 \\
\text { to } \\
\$ 2,500 .\end{array}$ & $\begin{array}{c}\$ 1,500 \\
\text { to } \\
\$ 2,000 .\end{array}$ & $\begin{array}{c}\$ 1,000 \\
\text { to } \\
\$ 1,500 .\end{array}$ & $\begin{array}{c}\$ 500 \\
\text { to } \\
\$ 1,000 \text {. }\end{array}$ & $\begin{array}{l}\text { Under } \\
\$ 500 \text {. }\end{array}$ & Total. \\
\hline \multicolumn{9}{|l|}{ Year 1908.} \\
\hline Northwest...... & 6 & 1 & 7 & 12 & 3 & 11 & 5 & 41 \\
\hline $\begin{array}{l}\text { Northeast............. } \\
\text { Southeast......... }\end{array}$ & $\ddot{2}$ & $\begin{array}{l}3 \\
3 \\
3\end{array}$ & $\begin{array}{r}18 \\
4\end{array}$ & $\begin{array}{l}10 \\
18\end{array}$ & $\begin{array}{r}17 \\
3\end{array}$ & $\begin{array}{l}12 \\
18\end{array}$ & 9 & $\begin{array}{l}7 \mathrm{7i} \\
50\end{array}$ \\
\hline Year 1904. & & & & & & & 6 & \\
\hline Northwest..... & 6 & 8 & 3 & $\begin{array}{l}6 \\
1\end{array}$ & 10 & 12 & 3 & 48 \\
\hline $\begin{array}{l}\text { Northeast............ } \\
\text { Southeast............ }\end{array}$ & $\ddot{6}$ & $\begin{array}{r}\ddot{9} \\
1\end{array}$ & $\frac{4}{7}$ & $\begin{array}{l}1 \\
15 \\
16\end{array}$ & $\begin{array}{l}13 \\
21\end{array}$ & $\begin{array}{l}14 \\
21\end{array}$ & $\begin{array}{l}\dddot{2} \\
6\end{array}$ & $\begin{array}{l}1 \\
63 \\
72\end{array}$ \\
\hline \multicolumn{9}{|l|}{ Year 1905.} \\
\hline $\begin{array}{l}\text { Northwest...... } \\
\text { Southwest..... }\end{array}$ & 11 & 2 & $\begin{array}{l}7 \\
1\end{array}$ & $\begin{array}{l}1 \\
1\end{array}$ & $\begin{array}{l}6 \\
2\end{array}$ & $\begin{array}{l}6 \\
4\end{array}$ & 4 & $\begin{array}{r}37 \\
8\end{array}$ \\
\hline Northeast....... & 7 & ii & 8 & 18 & 12 & 37 & 10 & 94 \\
\hline Southeast............... & 4 & 7 & 8 & 20 & 6 & 9 & 5 & 59 \\
\hline \multicolumn{9}{|l|}{ Year 1906.} \\
\hline $\begin{array}{l}\text { Northwest...... } \\
\text { Southwest. }\end{array}$ & 10 & 3 & 3 & $\begin{array}{l}5 \\
1\end{array}$ & 8 & $\begin{array}{l}7 \\
2\end{array}$ & 3 & $\begin{array}{r}39 \\
3\end{array}$ \\
\hline Northeast... & 7 & 5 & 10 & 19 & 19 & 35 & 10 & 99 \\
\hline Southeast..... & 2 & 10 & 18 & 12 & 3 & 18 & 5 & 68 \\
\hline \multicolumn{9}{|l|}{ Year 1907.} \\
\hline $\begin{array}{l}\text { Northwest...... } \\
\text { Southwest... }\end{array}$ & 16 & 5 & 3 & 7 & 3 & 1 & 6 & 41 \\
\hline Northeast.. & 4 & 7 & 21 & 13 & 19 & 10 & 6 & $\ddot{80}$ \\
\hline Southeast. & 3 & 5 & 13 & 11 & 9 & 13 & 2 & 56 \\
\hline Total for 5 years. & 84 & 80 & 135 & 186 & 154 & 230 & 77 & 946 \\
\hline
\end{tabular}

The dwellings included in this table are all situated outside the fire limits of the city and the great majority of them are, of course, in suburban communities.

Definite figures for the number of dwellings investigated in this table can not be given because of the uncertainty of locating the particular dwellings and because of the widely scattered locations of all. The examination developed the fact, however, that laboring men have no interest in any of these houses as possible dwelling places, except those in the last two columns-houses estimated to cost $\$ 1,000$ and less; in these columns are 307 dwellings. Fully 50 per cent of these have been built and are ornned by the occupants. a more independent class of people than those whom this commission needs to help. Eliminating, then, half of the dwellings costing $\$ 1,000$ and less, 153 frame dwellings have been provided in the past five years for people who can pay only $\$ 10$ or $\$ 12$ per month for rent.

It is apparent from all the facts set forth above that the house famine has met with scant relief. To sum up these facts, the case may be stated thus: Within the city not a single habitation, so far as

s. Doc. $599,60-2-6$ 
this investigation has disclosed, has been provided which can be rented for $\$ 12$ per month, except dwellings of the Washington Improvement Company and Sanitary Housing Company. Exclusive of these, 7 brick dwellings can be rented for from $\$ 14$ to $\$ 14.50$; and 140 flats can be had for from $\$ 13$ to $\$ 15.50$. Outside the city, 153 frame dwellings have been erected which may be rented for from $\$ 8$ to $\$ 12$ per month. Thus it appears that for the overcrowded, badly housed, laboring class of this city, 300 possible habitations have been constructed, under ordinary commercial conditions, in the past five years, or, expressed in another way, the house famine is being relieved at the rate of 60 dwellings a year.

H. C. Macatee.

The preceding report relates chiefly to new houses constructed during the past five years and shows that the supply has been entirely inadequate for the wants of the unskilled wage-earners of the city. This being the case, overcrowding of existing houses was to be expected, and that such is the case is shown by the investigation which has been made for the committee, under the direction of Mr. Gustavus A. Weber, statistician of the Department of Labor. To obtain the data desired with reference to housing conditions in various parts of the city the following schedule was prepared, and agents were employed to visit houses in the selected localities and fill the blanks in this schedule:

Schedule No. 1.-Housing of the People.

Washington, D. C., 190-.

1. House or apartment, No. —— street. 2. Brick, frame, concrete. 3. Stories, 1, 2, 3. 4. Story (apartment), - 5. Number of rooms, 6. Number of bathrooms, - 7. Number of closets, - - 8. Cellar, - 9. Back yard, —. 10. Exit to alley in rear, ㄴ. 11. Bathroom contains bath tub, water-closet, stationary wash basin. 12. Kitchen contains range, with water back, sink with hot and cold water, dresser, pantry. 13. No water in house or apartment. 14. Nearest water supply, closet in yard, in basement, in common hallway (apartment). 16. Privy in yard; condition of, - - 17. Porch in front of house or apartment rear - 18. House, old, new, in good repair, dilapidated, unfit for occupation. 19. Rent, - 20. Are walls damp? - 21. Is there ventilation under first floor? ——. 22. Roof of tin, shingle, slate, or ——; does it leak? 23. House front on street or alley, - 24. Width of street or alley, - 25. Dimensions of sitting room, _dows, -26 . Dimensions of dining room, $\_$; outside windows, $\overline{\text { - }}-$. 27. Dimensions of kitchen, ㄴ ; outside windows, - - 28. Dimensions of bedroom No. 1, — ; ouside windows, ——; number of occupants, ——. 29. Dimensions of bedroom No. $2, \longrightarrow$; ouside windows, $-\ldots$; number of occupants, - 30. Dimensions of bedroom No. 3, . 32. Is dining room so used? -33 . Is kitchen so used? - . 34. Gas in house, - 35. Heated by stove, steam, hot water, hot air.
36. Estimated ralue of house and lot, house, - 38. Number of families in house or apartment, - - 39. Number of boarders, - . 40. Number of occupants of apartment or of house in daytime, $\longrightarrow$; at night, ㄴ. 41. Adults, —— 42. Children, 43. Remarks :

NoTE.-Blank to be filled out for unskilled laborers, mechanics, clerks, and others having a yearly income of less than $\$ 1,000$.

The total number of schedules which have been completed is 1,251. The houses to which they relate are located as follows:

Northwest.-Cissel alley, Temperance avenue, Linger's court, Brainard street, Potomac street, Jackson Hall alley, King's court, 
Philip's court, Cleveland street, Shepherd alley, Valley street, O Street alley, Bank street, Snow alley, Goat alley, Jefferson street, Thirtieth street, Twenty-seventh street.

Northeast.-Gales street, Levis street, Brewer's court, Pleasant alley, Krramer street.

Southwest.-Riley's court, Twelfth street, Maryland avenue, Huntoon place, Union street, Van street, McLean street, Willow Tree alley, Nolan's court, F street.

Southeast.-L street, K street, Fourteenth street, Twelfth street, Fifth street, Thirteenth street, Georgia avenue, Mechanic's place.

Overcrowding of sleeping rooms is evidenly most important from a sanitary and also from a moral point of view; The investigation shows that 9 persons were sleeping in two of the bedrooms visited, 8 persons in another, 7 persons in three others, 6 persons in 9 others, 5 persons in 35,4 persons in 108 , and 3 persons in 404 . Three persons in a room, or even four, in the case of a married couple with one or two small children, could not be considered objectionable if the room were of sufficient size and properly ventilated. But the investigation shows that in 40 bedrooms the cubic air space for each occupant was less than 200 cubic feet, that it was more than 200 but less than 300 cubic feet in 167 , that it was more than 300 but less than 400 in 272 , that it was more than 400 but less than 500 in 276 , and that it was more than 500 but less than 600 in 302 bedrooms. It is difficult to fix upon a standard as to the number of cubic feet of air space per person which should be required by regulation as a minimum allowance. Evidently 300 cubic feet per person with an open window is better than 600 cubic feet with closed windows and doors. No doubt many poor people who are obliged to live in houses having small bedrooms are in the habit of learing the bedroom door open at night. But there is great objection, especially among the colored population, to sleeping with an open window. While it would be extremely desirable to provide at least 600 cubic feet of air space for each person, this appears to be difficult of attainment from an economical point of view, and in the absence of any ventilation it would be inadequate. To give this amount of air space to two persons a bedroom should be 10 by 12 feet in floor area and 10 feet high. But bedrooms of this size are the exception in houses built for the lowest class of wage-earners. Ample ventilation will compensate to a great degree for restricted air space; on the other hand, a hermetically sealed bedroom is insanitary, no matter how ample the cubic air space may be. The probability is that in the bedrooms referred to above as occupied by four, five, six, seven, and even by eight and nine persons having an air space of less than 300 and even of less than 200 cubic feet per person the window or windows are not left open at night in winter weather and the occupants are obliged to rebreathe this vitiated air until it is absolutely fetid and poisonous. Our investigtion shows that 856 bedrooms scheduled have more than 600 cubic feet of air space per occupant, and most of these were occupied by one or two persons only. It also shows that 803 bedrooms had one outside window and 1,109 had two outside windows. The comparatively large number of bedrooms with two outside windows indicates that the old houses in Washington are better provided in this way than are those recently bulit. It is seldom that new houses for this class of tenants have bedrooms with more than one outside window. 
The total number of families included in the investigation made under the direction of Mr. Weber was 1,251. Of these, 666 were colored, 582 white, and 3 mixed. The total number of houses occupied by these families was 1,054 . The different sections of the city are represented as follows: Northwest, 498; northeast, 144; southeast, 141 ; southwest, 277. Seven hundred of these houses are of brick and 354 of frame. Sixty-six are reported as "new and in good repair;" 634 as "old and in good repair ;" 99 as "old and in fair repair;" 237 as "old and dilapidated " and 18 as "old and unfit for occupation." A majority of these old houses have no water in the house. In 569 houses there is water in the yard but not in the house; in 331 there is cold water in the kitchen and in 137 the kitchen is supplied with both hot and cold water; 868 have water-closets in the yard; 153 have bathrooms with water-closet in the house; 5 have water-closets in common hall; 4 have water-closets in basement; and 24 have box privies in the yard. In 13 of the houses scheduled there is no water on the premises. With reference to the number of rooms occupied by each family we have the following data: Sixty-two individuals or families (?) occupy a single room, 171 have two rooms, 116 three rooms, 406 four rooms, 214 five rooms, 244 six rooms, 18 seven rooms, and 20 more than seven rooms. We have the following additional data with reference to the physical condition of the houses: Twenty-eight are of one story, 972 of two stories, 51 of three stories, and 3 of four stories. Four hundred and fifty are reported as having "ventilation under the first floor," and presumably the remaining 604 houses are without ventilation under the first floor. This is a fundamental fault in the construction of a large proportion of the old houses of low cost in the city of Washington. Two hundred and twenty-nine of the houses scheduled have cellars. Nearly all $(1,038)$ have a yard at the back or side of the house. There are porches in front of 264 of these houses, porches in rear of 57 , and porches both in front and rear of 88. The walls are reported as damp in 139 houses and the roofs as leaking in 120 .

The total number of occupants of 1,054 houses scheduled is 5,159. Of these, 2,603 are white and 2,556 colored. The number of adults is 3,381 ; the number of children, 1,778 . The figures given include 246 adults taken as boarders by the families occupying these houses.

VII. RENTS PAID BY WORIKINGMEN IN WASHINGTON AND ELSEWHERE.

The "cost of shelter" will, of course, depend upon the character and locality of the dwelling. A frame house in the suburbs where land is cheap can be rented at a much lower figure than a brick house having rooms of the same number and dimensions in the city. The working man must pay for a central location, sewer connections, city water and gas supply, cement sidewalks, paved alleys, etc. All of these items add to the cost of a sanitary city house, no matter how great an effort is made to build it as cheaply as possible. Building regulations must be complied with as regards foundations, thickness of walls, dimensions of rooms, light, and ventilation. There is, therefore, a minimum cost of construction which varies from year to year according to the cost of labor and materials. And the cost of the completed house will depend upon the value of the land upon which it 
is built; the number of houses built at one time; the plan, including the presence or absence of bathrooms, closets, etc.; the interior finish, including the presence or absence of mantels, painting, papering, etc. In considering the cost of shelter, in the present section, the writer has in view houses intended for workingmen and especially for unskilled laborers, whose income does not permit of a tax, in the shape of rent, upon exterior and interior decorations, mantelpieces, closets, etc. What is absolutely necessary is a certain number of rooms, according to the size of the family, and a water-closet connected with the sewer, either inside the house or in the yard. In the opinion of the writer, a bathroom, with hot and cold water, should also be regarded as necessary, in the present state of civilization, and building regulations should require every house or independent flat to be provided with a bathroom, in which the water-closet should be placed, rather than in the yard. A large proportion of the houses in Washington built to rent to the laboring classes have no bathroom in the house. Many of these houses have a shed in the back yard containing a very cheap form of water-closet. Many others have open-box privies. In the tenement houses of New York and other cities, one water-closet at the end of a common hall is often made to do service for several families. An independent bathroom for each family, of course, adds to the rental value of a house or flat; but it also adds greatly to the comfort and respectability of the occupants. While those who have never taken a bath may prefer not to pay more rent for a house because it is provided with a bathroom, they are likely to learn to use it after a time if it is always at hand. And the children, who go to school and come in contact with clean and well-dressed children from homes a little higher in the scale of civilized life, will soon learn to make use of the bath tub, if it is in a warm room and is provided with an ample supply of hot and cold water. A supply of hot water, to be drawn at will from a faucet over the bath tub, calls for a stove with a water back, or some special appliance for heating the water. In planning houses for wage-earners in Washington, more than ten years ago, the writer had in view these requirements, and all houses built by the two companies with which he is connected have a good range with water back in the kitchen and a bathroom provided with a bath tub supplied with hot and cold water; also a modern type of water-closet, and usually with an enameled wash basin, having faucets for hot and cold water. These appliances, together with a kitchen sink supplied with hot and cold water, add considerably to the cost of a house and consequently to the rent. The problem of providing independent "homes" for day laborers, supplied with these requisites of modern civilized life, at rentals which this class of workingmen can afford to pay, is a difficult one. But we believe it is not insoluble, as will be shown hereafter.

It is evident that it is not fair to compare the rental, per room, of a well-built brick house provided with a bathroom, one or more closets, and a range with water-back in the kitchen, with a more or less dilapidated frame structure, having a "running" water-closet in the back yard. Moreover, in making a comparison as to rentals the size of the rooms must be considered. In many of the old houses now occupied by workingmen in the city of Washington the kitchen is a small shed in the rear of the main building, yet it counts as a room, and as a rule no kitchen stove is provided by the landlord. The rooms 
are also, as a rule, of very modest dimensions - often not more than 8 by 10 feet; yet the monthly rent, per room, of these old houses is from $\$ 2$ to $\$ 3$ or more. The rent per room of a well-built twostory brick house will depend upon its location (cost of land) and upon the demands of the capital invested in the way of interest. We shall show later that it is quite possible to construct houses and rent them at less than $\$ 3$ a room, if the two-flat plan is adopted and dividends of a company organized to construct them are limited to 4 per cent. This is shown by the experience of the Washington Sanitary Housing Company, which was organized under a charter from Congress in 1904. The act of incorporation is as follows:

\section{AN ACT TO INCORPORATE THE WASHINGTON SANITARY HOUSING COMPANY.}

Be it enacted by the Senate and House of Representatives of the United States of America in Congress assembled, That Henry Y. Satterlee, Teunis S. Hamlin, John M. Harlan, S. Walter Woodward, Brainard H. Warner, John Joy Edson, Maximilian G. Seckendorff, Wallace Radcliffe, Clement Brown, John W. Foster, George M. Sternberg, Henry B. Brown, David J. Brewer, Crosby S. Noyes, George M. Kober, Charles C. Glover, Charles J. Bell, Henry F. Blount, Charles B. Purris, Francis J. Grimke, Frederick A. Miller, J. W. Pinchot, Mary L. D. Macfarland, Elizabeth J. Somers, Herbert Wadsworth, George Truesdell, John F. Wilkins, Simon Wolf, Henry A. Willard, J. Henry Small, jr., Augustus S. Worthington, Emily Tuckerman, Thomas W. Smith, Clare G. Addison, John B. Larner, Bernard T. Janney, Tallmadge A. Lambert, Charles F. Weller, G. Lloyd IIagruder, Charles E. Foster, E. Francis Riggs, Alexander Graham Bell, Samuel R. Bond, Caleb C. Willard, and George H. Harries, their associates and successors, be, and they are hereby, created a body corporate and politic in the District of Columbia by the name, title, and style of the Washington Sanitars Housing Company, and by that name have perpetual succession, and it shall be lawful for the said corporation to hare a common seal, sue and be sued. plead and be impleaded, and hare and exercise all the rights, privileges, and immunities for the purposes of the corporation hereby created, which purposes are declared to be to acquire, hold, improre, rent, mortgage, sell, and conrey real estate within the District of Columbia, for the building of sanitary houses for the poor, to replace the insanitary houses now occupied by them, especially in the allers, and to rent such houses at so low a rental that dilapidated and insanitary houses will be abandoned by their tenants when, as a result of this work, better houses can be secured at the same or a lower figure: Provided, That the value of any and all property so acquired shall not exceed the sum of fire hundred thonsand dollars: And provided further, That no land shall be acquired or houses built thereon except of the character hereinbefore described.

SEc. 2. That the capital stock of said corporation shall be twenty-five thousand dollars, dirided into two hundred and fifty shares of the par ralue of one hundred dollars each, and when said amount shall have been subscribed the said corporation shall be fulls authorized and empowered to commence business: Provided. That said capital stock may be increased by the sale of additional stock from time to time, but the total issue thereof shall not exceed the sum of five hundred thousand dollars: And provided further, That it shall be unlawful for the officers or directors of said corporation to declare any greater dividend to the stockholders than four per centum per annum upon the capital stock outstanding at the time of any such dividend.

SEC. 3. That the affairs of the corporation shall be managed by a board of directors consisting of fifteen persons, who shall for the first year be elected by the incorporators hereinbefore named, from their number, and thereafter said board shall annually be elected in such manner as may be provided by the by-laws of the corporation, and such board of directors shall hare porrer to ordain, establish, and put in execution such rules, regulations, ordinances, and by-laws as they may deem essential for the good government of the corporation, not contrary to the laws and the Constitution of the United States, or of this act, and generally to do and perform all acts, matters, and things which a corporation may or can lawfully do.

SEc. 4. That Congress reserves the right to repeal, alter, or amend this act.

Approved, April 23, 1904. 
The object of the company was stated by the present writer as follows:

The object of the company is to build sanitary houses for a deserving class of the population which can not afford to pay the rentals of from $\$ 10$ to $\$ 16$ per month, which the better class of wage-earners pay for the flats of the Washington Sanitary Improvement Company. To bring the rentals within the reach of this class, it is necessary to build on cheaper land and to leave out certain features (bay windows, cellars) which add to the expense of construction. It is not proposed to provide for the idle and the dissolute, and only those who pay their rents and take reasonable care of the apartments will be retained as tenants. The dividends are limited to 4 per cent, but the rentals are placed at such a figure as to insure a 4 per cent dividend and a surplus fund of 2 per cent per annum after paying all expenses. The difference between 4 and 5 per cent in dividends goes to the benefit of the tenant, and enables the company to establish the lowest possible rentals. The company is practically under the same management and will have the benefit of the experience gained in conducting the business of the Washington Sanitary Improrement Company.

The company, organized under the above charter from Congress, succeeded in securing stock subscriptions sufficient to justify it in commencing building operations, and in October, 1904, 20 houses had been completed and were occupied by colored tenants. Seventeen of these houses were on Van street SW. (See figure 7.) The flats of three rooms and a bath were rented for $\$ 7$ per month for lower and $\$ 7.50$ per month for upper flats. The four-room flats were rented for $\$ 8$ and $\$ 8.50$ per month. This is an average of $\$ 2.26$ per room. It should be remembered that each of these flats has a good-sized bathroom, with a bath tub and a modern water-closet. There is a good range with water-back in the kitchen and a small coal stove in the front room. The hot-water boiler connected with the kitchen range is placed in the bathroom and furnishes sufficient heat to make it comfortable. These flats have now been occupied by colored tenants, mostly day laborers, for nearly four years. They are in such demand that there is constantly a waiting list of applicants in case a flat becomes vacant. Many of the present tenants have occupied their flats since the houses were completed. The repairs required have not been excessive and there has been very little loss from vacancies or failure to collect rents. The company has paid 4 per cent dividends from the outset, and at the end of the second year was able to report a surplus of $\$ 1,211.18$. When the statement is made that these flats are rented at an average of $\$ 2.26$ per room per month, it should be remembered that the company only receives eleven months' rent in the year. The twelfth month's rent is devoted to interior repairs in accordance with the plan adopted by the Sanitary Improvement Company at the outset of its operations in 1898, at the suggestion of the present writer. Under this system one month's rent in each year is devoted to interior repairs, and if no repairs are needed a rebate is made of the entire month's rent. The tenant has thus a special inducement to take care of his flat, and when repairs are needed he has the choice of making them himself or of reporting them to the agent, who has them made and charges the cost against the rebate. The tenant certifies in the bill that the repairs have been made and are satisfactory. At the end of eleven months the agent inspects the flat and causes all necessary repairs to be made; whatever balance remains after paying for these repairs constitutes the rebate to be deducted from the twelfth month's rent. This method insures excellent care of the premises, as it is in the interest of the tenant to 


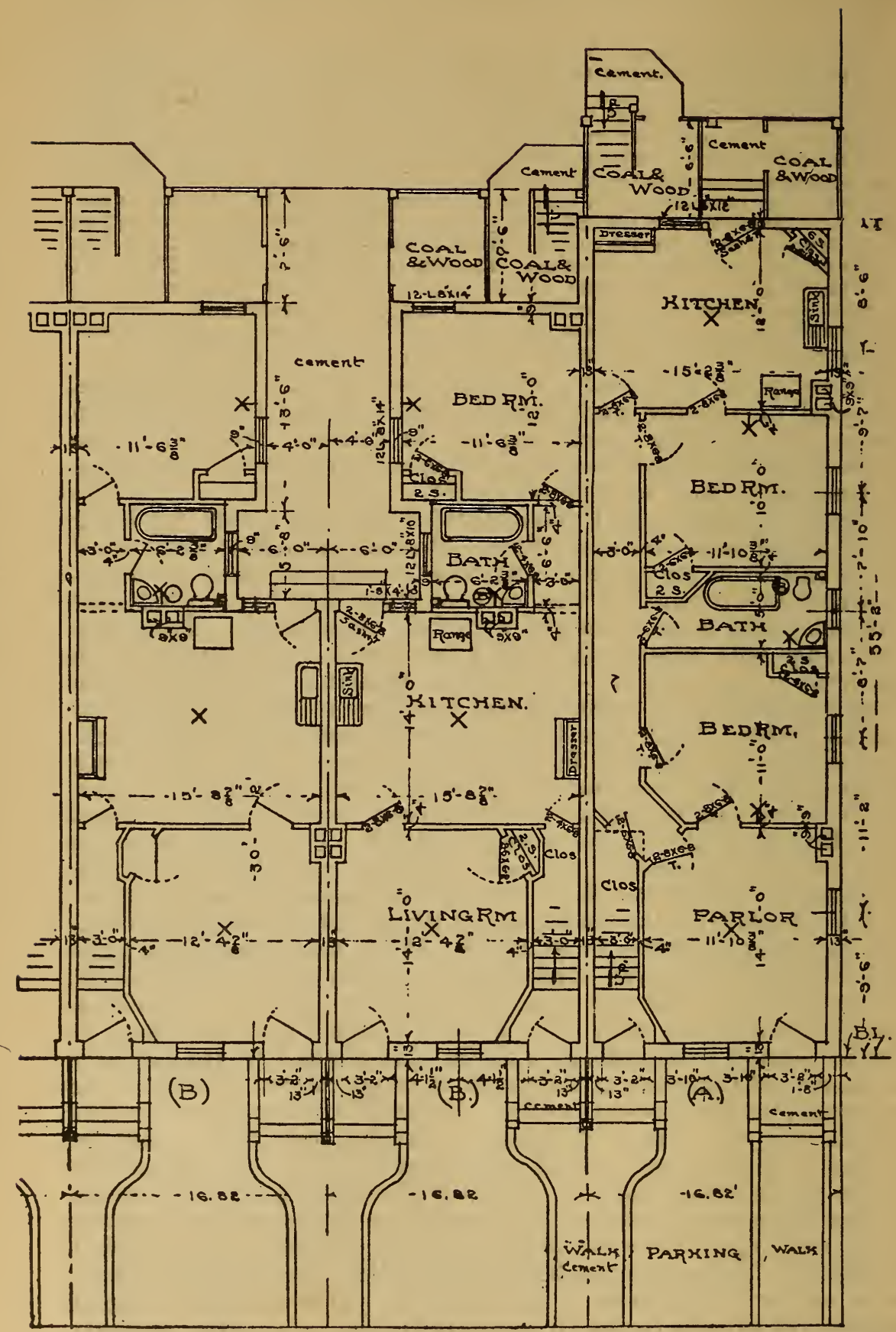

FIG. 31.-First-story plan of three and four room and bath flats of the Washington Sanitary Housing Company. 
make the bill for repairs as low as possible, because it comes out of his "rebate." On the other hand the agent of the company insists that all repairs must be made before the balance, if any, from the twelfth month's rent is paid to the tenant.

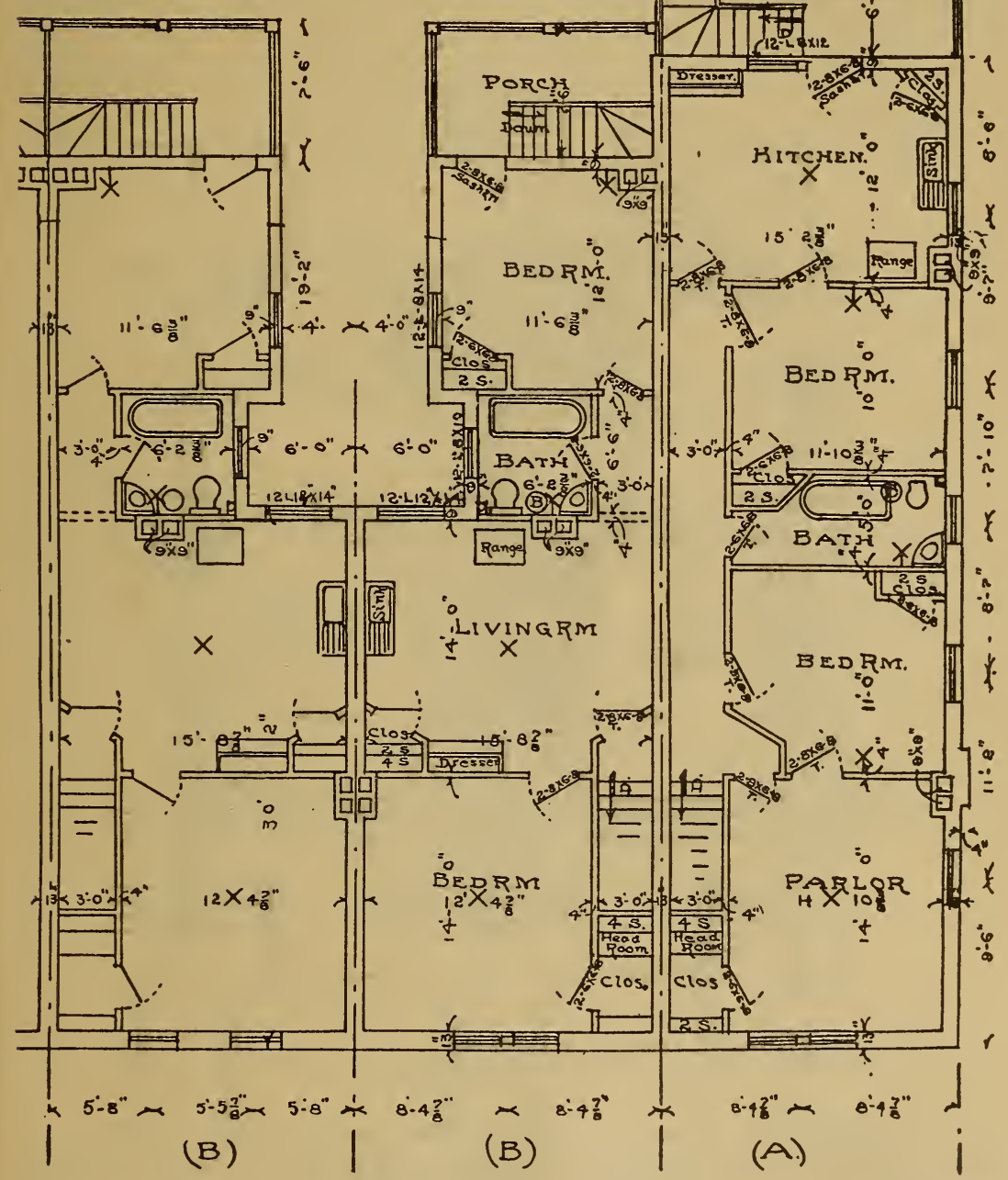

Fig. 32.-Second-story plan of three and four room and bath flats of the Washington Sanitary Housing Company.

In 1907 the Sanitary Housing Company built 20 more two-flat houses on M street SW. At this time the cost of labor and materials had considerably advanced. The plans adopted also involved a greater expense for construction, and when the houses were completed it was found necessary to fix the rentals at $\$ 8$ per month for two rooms and bath, $\$ 11$ for three rooms, and $\$ 14$ for four rooms, or an average of $\$ 3.72$ per room per month. These flats are occupied by white 
tenants. The rooms are of good size and conveniently arranged, as shown by the plans. (Figs. 31, 32, 33, and 34.)

Attention is especially invited to the large kitchens (15 feet $8 \frac{7}{8}$ inches by 14 feet) in the three-room flats. The tenants use this kitchen also as a dining room, and they find that in the three-room flats the fire in the kitchen range heats the whole flat, thus reducing the cost of fuel to a minimum.

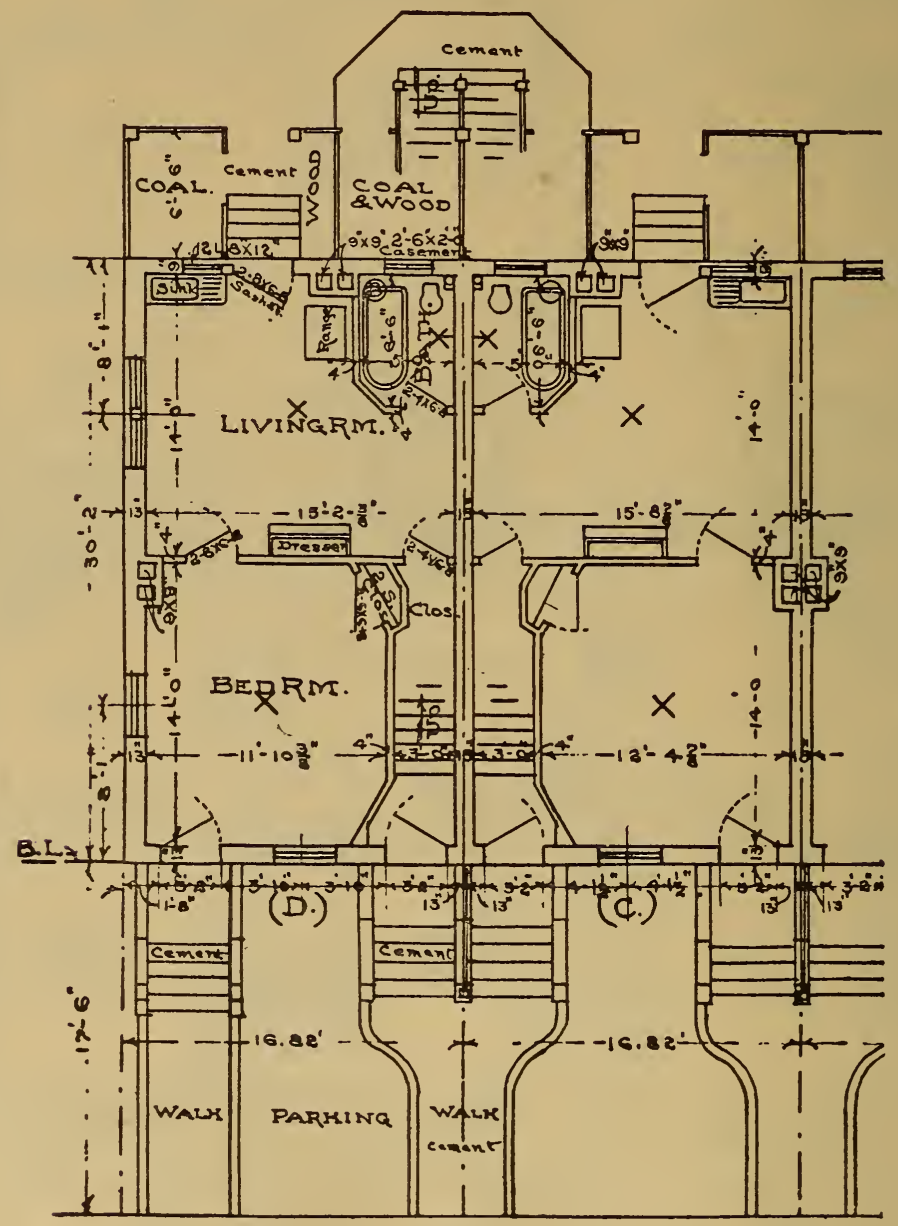

FIG. 33.-First-story plan of houses belonging to the Washington Sanitary Housing Company; two rooms and bath.

The two-room flats were built as an experiment, but it was found that the cost of construction was considerably greater in proportion to the number of rooms than that of three and four room flats.

This is due to the fact that the plumbing, bathroom fixtures, range, etc., cost as much for a two-room flat as for one containing three, four, or more rooms. It was necessary to fix the comparatively high rental of $\$ 4$ per room for these two-room flats. Evidently the persons occupying them must use the front room both as bedroom and sitting 
room. It would seem that in the interest of economy this might often be done by a family of two. Eight dollars a month for an independent apartment of two rooms and bath does not seem excessive, and it is a distinct saving for a young married couple, or old people without children, or a widow, to occupy a two-room apartment at this rate rather than a three-room apartment at $\$ 11$ monthly rental. In considering these plans and rentals, the value to tenants of the porch in the rear of the upper flat should be given due consideration, also the cement areaway between adjoining houses, as shown in figure 31, and the cement walk leading from the front steps to the sidewalk.

The first eight houses built by the Washington Sanitary Improvement Company in 1898 have been rented at an average of $\$ 3.16$ per room. The plan of these houses is shown in figures 35 and 36 .

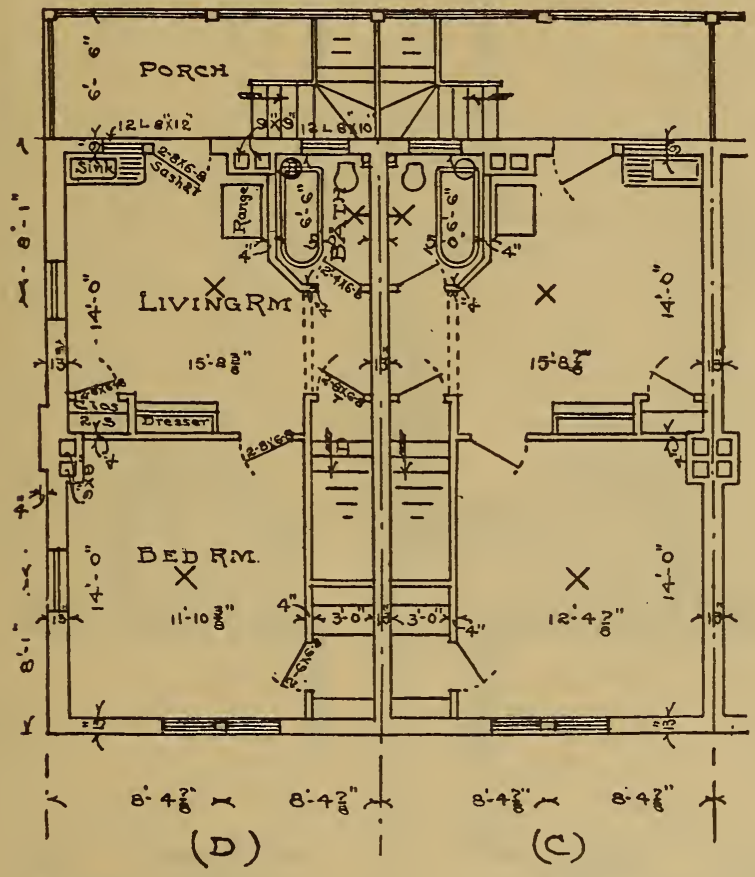

Fig. 34.-Second-story plan of houses belonging to the Tashington Sanitary Housing Company; two rooms and bath.

The block of houses erected by the Washington Sanitary Improvement Company on $\mathrm{O}$ street, between North Capitol and First streets NT., is rented to colored tenants. These houses contain three and four room flats; each flat has a bathroom, with hot and cold water; a back yard, with exit to an alley, and a cellar. The monthly rental (for eleren months) averages $\$ 3.18$ per room. These flats have been continually occupied since their completion in 1902 by a good class of tenants, and losses as a restilt of racancy or failure to pay rent have been insignificant.

The investigations of the committee, made under the direction of Mr. Weber (see p. 82), show that the poorer class of wage-earners in Washington living in old houses, many of which are dilapidated 


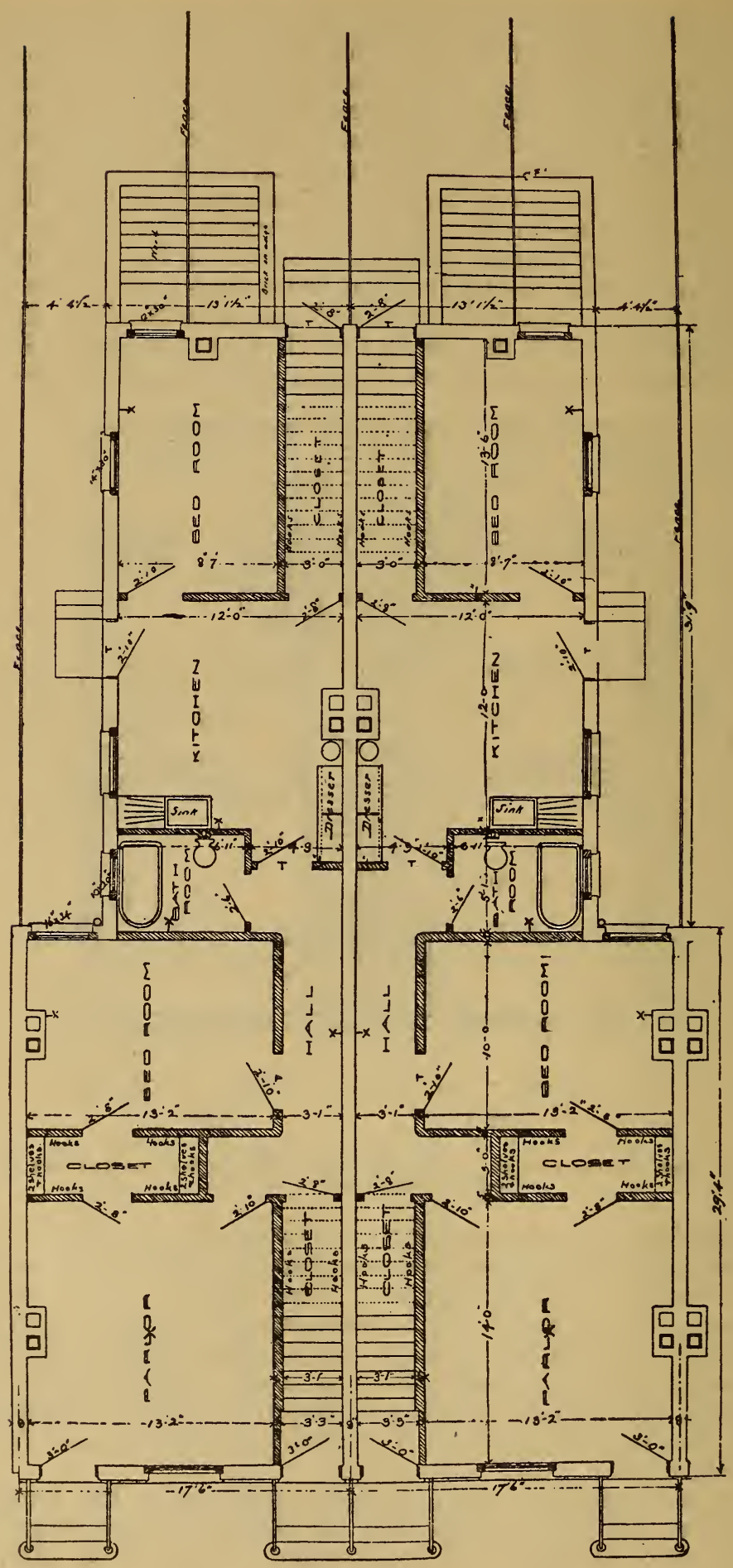

FIG. 35. - First-story plan of houses of the Washington Sanitary Improvement Company. 
and leaky, and a large proportion of which have no water in the house, pay on an arerage from $\$ 2$ to $\$ 2.70$ per room. In comparing these rentals with those paid for new houses, which average from $\$ 3$ to $\$ 4$ per room, it must be remembered that new houses, such as are supplied by the Washington Sanitary Improvement Company, are built of brick, on lots having a frontage of at least 16 feet, in accordance with existing building regulations. Many of the old frame and brick houses have a frontage of only 12 or 14 feet. The rooms of the new houses are in every way superior. Moreover, the bathroom, supplied with hot and cold water; the range, with water back, and the kitchen sink, with hot and cold water, add to the expense of construction considerably more than the cost of an additional room. If, for example, in the new houses now being built in the southwest section of the city (see p. 43), the bathroom should be counted as an additional room, the rentals fixed for the four-room apartments ( $\$ 11$ per month) would only be $\$ 2.20$ per room. No doubt many of the families occupying the old houses with six small rooms would prefer to pay for an additional bedroom or two rather than for a bathroom. They consider the water-closet in the yard quite satisfactory, and an extra bedroom enables them to take a boarder, who gives material assistance in paying the rent. But from a sanitary and moral point of view it is far better for them to get on without the boarder and to acquire the bath habit. The children, especially, who will be taught the gospel of cleanliness in the public schools, should be given an opportunity to put in practice what they learn. It would seem to be the duty of the municipality to see that they have proper facilities for keeping clean as well as for learning the rudiments of sanitation in the schools.

An attempt has been made to estimate the amount paid in rent for houses included in our schedule as compared with the value of the property. The estimated value, as made by our agents, is of course not exact, and in some cases may vary greatly from the market value, which often depends upon the location and dimensions of the lot, rather than upon the building. Taking the estimates given in the completed schedules, we find that a large proportion of the houses are estimated to be worth less than $\$ 1,500$. There is as great discrepancy in the rents paid in comparison with the estimated value. Thus we have 29 houses, estimated to be worth $\$ 2,000$ each, which are rented from $\$ 12$ to $\$ 23.50$ per month. At $\$ 12$ per month the owner would only receive 7 per cent gross on the value of the property. But 10 of these houses are rented at $\$ 15$ per month, which gives a return of 9 per cent gross. This is a fair return, and can not be regarded as excessive. But when we make a similar comparison for the houses of lower valuation we find that the rentals asked are often excessive. Thus we have 15 houses, estimated to be worth $\$ 450$ each, which are rented for $\$ 7$, which gives a return of 18 per cent gross on the value of the property. Nine houses, of the same estimated value $(\$ 450)$, are rented for $\$ 8$, and 8 houses for $\$ 8.50$ per month, which gives a return of about 22 per cent gross. Fourteen houses, estimated to be worth $\$ 500$ each, are rented for $\$ 6$ per month-about 14 per cent on the value of the property. Twenty-three houses, estimated at $\$ 600$. rent for $\$ 10$ per month-a return of 20 per cent gross on the value of the property. We have 24 houses, of an estimated value of 


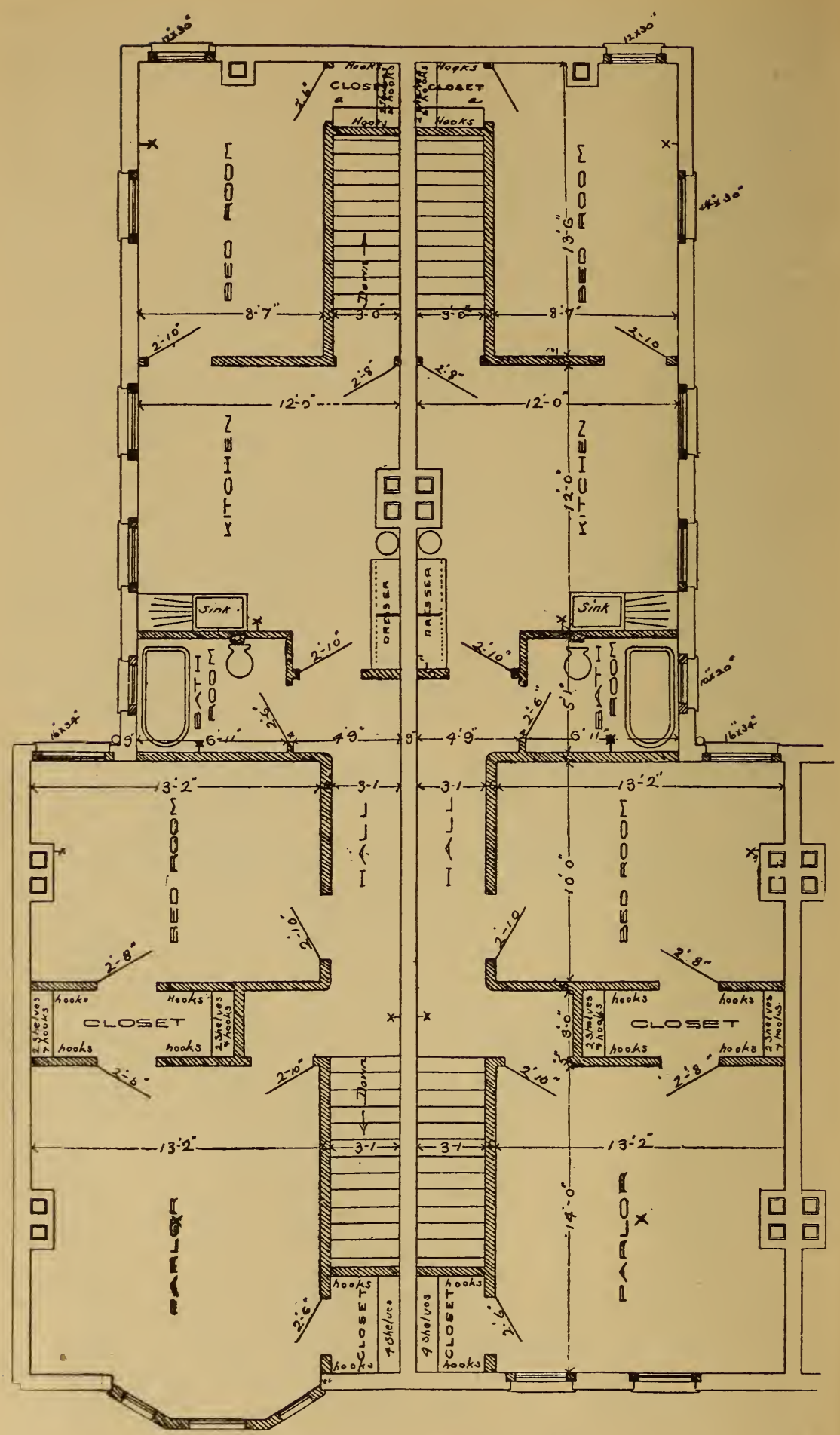

FIG. 36.-Second-story plan of houses of the Washington Sanitary Improvement Company. 
$\$ 800$, which rent for $\$ 8$ per month-a return of 12 per cent gross. Twenty-one houses, of the same value $(\$ 800)$, rent for $\$ 9$-equal to 13 per cent on the estimated value. 'Taking some extreme cases, we have four houses renting for $\$ 12.50$ per month, which are estimated to be worth $\$ 450$ each - a return of 35 per cent gross; 3 houses. valued at $\$ 600$, rent for $\$ 15$ per month-a return of 30 per cent; 1 house, valued at $\$ 350$, rents for $\$ 12$ per month; a house, valued at $\$ 100$, rents for $\$ 12.50$; a house, valued at $\$ 450$, rents for $\$ 12.50 ; 3$ houses, valued at $\$ 500$, rent for $\$ 12, \$ 12.50$, and $\$ 13 ; 3$ houses, valued at $\$ 600$, wrent for $\$ 15$-a return of 30 per cent. It is unnecessary to give additional examples, but it is evident that many of the poorer residents of the city of Washington are obliged to pay exorbitant rents for very indifferent shelter, and these houses are often overcrowded to an extent which should not be tolerated in any civilized community-certainly not in the national capital.

Dr. Henry C. Macatee has collected data for the committee with reference to the rentals now being paid by Washington workingmen for the different types of houses occupied by them. He reports as follows:

Three hundred and sixty-five new dwellings, all erected during the past five years, all within the city, all of brick, and none estimated to cost over $\$ 2,000$, have been examined with respect to rentals charged, and, when for sale, with respect to the sale price asked. The information having been obtained by visiting the houses, it was not always possible to ascertain at what valuation the property was held; in other instances, all the houses in a block of dwellings were owned by the occupants and no information was to be had as to rentals; in many rows some were owned by the occupants, others were rented; in these both sale price and rentals could be ascertained.

The information thus obtained is summarized as follows:

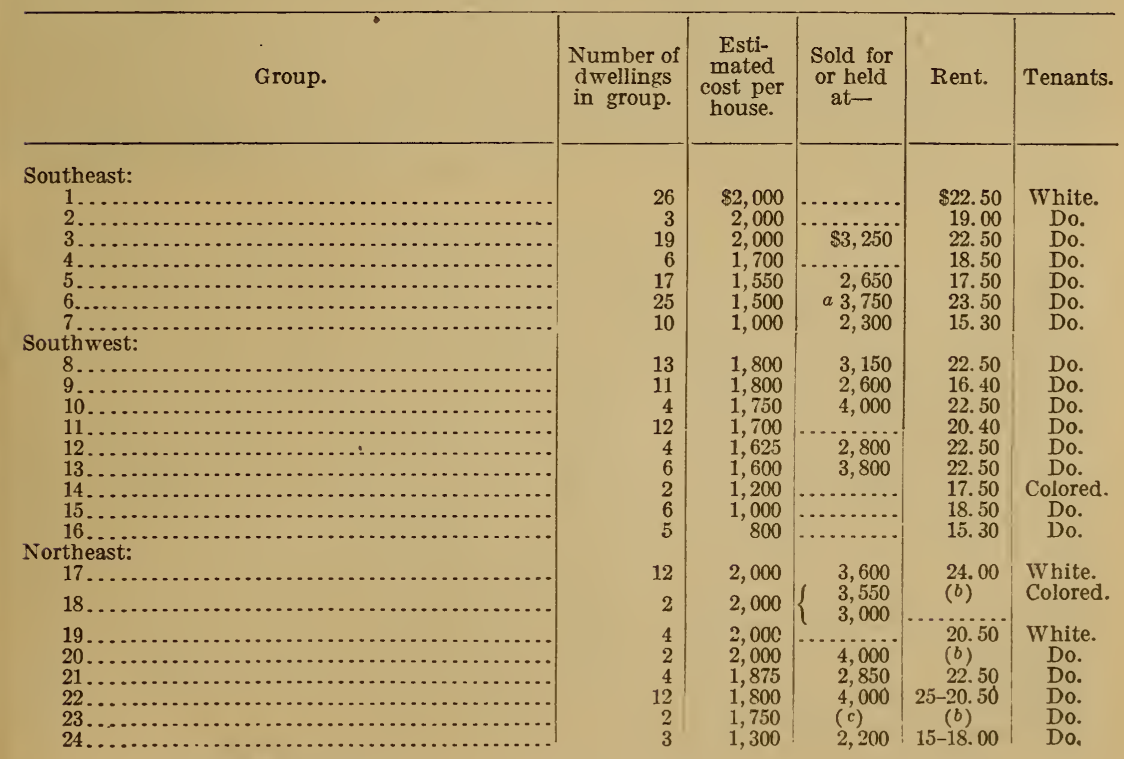




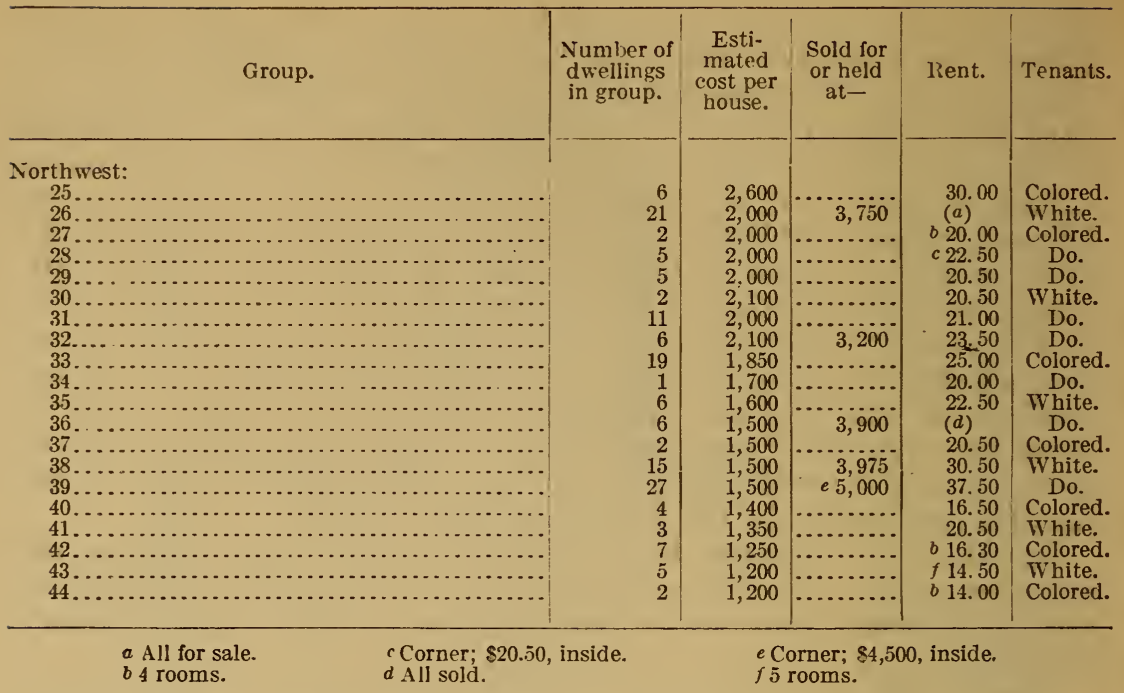

The dwellings investigated were usually built in rows, one building permit having been issued for the entire group. The first column in the table may be used as an index to the various groups; the second column of figures indicates the number of houses in each group. All of these dwellings contain six rooms and bath unless otherwise indicated; they are provided with bathroom containing water-closet, hot and cold water supply, and gas supply, with these exceptions: Groups 14 and 43, no gas supply; groups 16, 40, and 44, no gas supply and no provision for hot-water supply. All are in good condition, except group 43, which are dark, cramped houses on Valley (now Thirty-second) street, in Georgetown; in one of these houses, erected in 1903, the flooring had rotted and was entirely absent over a third of the floor space in the front room. The tenants said that the floor had been in that condition for several months and the owner refused repairs. No ventilation under the ground floor had been provided in these houses, but it was commonly present in the other houses examined.

It may be seen from the table of the 365 dwellings investigated 21.6 per cent rent for less than $\$ 20$, while 1.9 per cent rent for less than $\$ 15$. Selection was made of the houses in the class investigated, so as to bring under inspection dwellings of the least cost and in the most undesirable neighborhoods; it is felt, therefore, that the above figures indicate with a fair degree of accuracy minimum rentals.

The average sale price of 189 of these houses (all six-room and bath) was $\$ 3.260 .94$; the average rental charged was $\$ 22.64$; thus calculated, the average return on investments of this sort is 8.3 per cent. But the average cost of construction of the same houses was $\$ 1,668.75$, leaving a margin of $\$ 1.592 .19$, or 95 per cent for cost of lot, grading, sewer, gas and water connections, etc., and profit on the operation. These 189 dwellings, hotrever, are all occupied by independent white (a few colored) people, many of whom have bought the houses in which they live. 
If we examine groups $14,15,16,27,42,43$, and 44 , all occupied by colored people of the better class of laborers, except group 43 occupied by whites, we find that there are 29 such dwellings, 13 of six rooms, 5 of five rooms, and 11 of four rooms. These houses are unpapered, some have no gas supply, and some no supply of hot water; 5 , group 43 , are in bad repair. The average cost of these dwellings was $\$ 1,235.70$ each; to which if we add 95 per cent for lot, grading, water connection, etc., $\pi$ e arrive at $\$ 2,409.67$ as the total investment. The average rental of these dwellings was $\$ 16.60$; thus, the gross returns on the investment may be set at 8.27 per cent, practically identical with the gross returns from the better houses. It would appear, if these figures be approximately correct, that since the average rental of $\$ 16.60$ for a four or five room house, without gas, and often without hot water, furnishes only the usual return on the investment, to venture below that figure could be attempted in single brick dwellings only with the sacrifice of necessary hygienic space or sanitary equipment.

The table indicates, also, that to dwell in a new six-room house, on a street or avenue in a desirable location, the clerk or mechanic must pay $\$ 22.64$ rent; that is to say, $\$ 3 . \tau T$ per room per month. The day laborer has had provided only a very few new four and five room houses, the arerage rent of which was found to be $\$ 16.60$, or $\$ 4.15$ per room for a four-room house, and $\$ 3.34$ per room for a five-room house, located on minor streets or in undesirable neighborhoods, and wanting gas supply and provision for hot-water supply; the latter fact meaning that the tenant must furnish all of the necessary stoves. It would seem, therefore, that adequate provision is made for housing the clerk and mechanic class at fairly reasonable rates, although the housewives complained rather feelingly of high rentals.

In the provision for the day-laborer class, the greatest difficulty is the scant supply of houses a vailable; the houses of this class and type here tabulated are sound, sanitary, and comfortable as a rule, and if they can be rented for $\$ 16.60$, as we have seen they are rented, there is no excuse for a condition which makes it necessary for day laborers to pay $\$ 10, \$ 12$, and $\$ 14$ for the crazy four-room shacks which crookedly stand along many of our streets.

\section{TWO-FLAT HOUSES.}

In the past five years 1,748 tro-flat houses have been erected, thus providing shelter for 3,496 families. Of these, 139 houses belong to the Washington Sanitary Improvement Company and to the Sanitary Housing Company, and have been already fully described and the rentals given. Stimulated by the operations of these companies, and profiting by the plan used by them, private enterprise has caused the erection of the remaining 1,609 houses of this type. The table on page 86 will throw some light upon the rentals asked when the building is left to ordinary business conditions.

It is evident from a study of this table that the introduction of this type of dwellings has had a good effect, and that shelter of excellent quality at fairly reasonable rates may already be had. In this class of building, as in all others, the disposition, however, is to build for the best class of tenants likely to live in the neighborhood, and for this

S. Doc. $599,60-2-7$ 
reason furnaces for each flat have been installed in many of the houses, thus in most instances bringing the rent above $\$ 20$ for fiveroom flats. In all of the buildings listed the walls have been papered and a back porch and yard provided; for these things, of course, the tenant pays in his rent.

\begin{tabular}{|c|c|c|c|c|c|c|}
\hline Group. & $\begin{array}{c}\text { Number of } \\
\text { houses in } \\
\text { group. }\end{array}$ & $\begin{array}{l}\text { Estimated } \\
\text { cost each } \\
\text { house. }\end{array}$ & $\begin{array}{c}\text { Rooms } \\
\text { contained } \\
\text { (and bath). }\end{array}$ & How heated. & Rent. & Tenants. \\
\hline \multicolumn{7}{|l|}{ Northwest: } \\
\hline 1. & 6 & $\$ 4,100$ & 5 & Furnace.. & $\begin{array}{r}\$ 25.00 \\
27.50\end{array}$ & White. \\
\hline $2 .$. & 6 & 2,500 & 4 & Latrobe and range & $\begin{array}{l}20.50 \\
21.00\end{array}$ & Colored. \\
\hline 3. & 3 & 2,400 & 5 & .....do..... & 20.50 & Do. \\
\hline $4 .$. & 11 & 4,550 & 5,6 & Furnace... & $\begin{array}{l}25.50 \\
27.50\end{array}$ & \}White. \\
\hline 5. & 10 & 4,000 & 5,6 & ..... do.. & $\begin{array}{l}25.50 \\
27.50\end{array}$ & Do. \\
\hline $6 .$. & 11 & 3,000 & 5 & .....do.. & $\begin{array}{l}21.00 \\
22.50\end{array}$ & Do. \\
\hline 7. & 8 & 4,000 & 5 & .....do. & $\begin{array}{l}21.00 \\
22.50\end{array}$ & Do. \\
\hline 8. & 10 & 2,800 & 5 & ..... do. & $\begin{array}{l}20.50 \\
21.50\end{array}$ & \} Do. \\
\hline 9. & 11 & 3,100 & 4 & Latrobe and range & $\begin{array}{l}17.50 \\
18.50 \\
18.25\end{array}$ & Colored. \\
\hline 10. & 9 & 3,000 & 4 & Furnace... & $\begin{array}{r}19.25 \\
a 20.50 \\
21.50\end{array}$ & White. \\
\hline $11 \ldots$ & 4 & 3,750 & 5 & Latrobe and range & 22. 50 & Do. \\
\hline $12 \ldots$ & 4 & 2,000 & 4 & Stove and range. & $\begin{aligned} & 15.50 \\
& \text { b } 18.00\end{aligned}$ & Colored. \\
\hline \multicolumn{7}{|l|}{ Northeast: } \\
\hline $13 \ldots \ldots$ & 21 & 2,800 & 4 & ...do.............. & 14.50 & White. \\
\hline $\begin{array}{l}14 \ldots \\
15 \ldots\end{array}$ & $\begin{array}{r}9 \\
12\end{array}$ & $\begin{array}{l}3,500 \\
2,200\end{array}$ & $\begin{array}{l}5 \\
4\end{array}$ & $\begin{array}{l}\text { Latrobe and range } \\
\text { Stove and range }\end{array}$ & $\begin{array}{l}17.50 \\
14.50\end{array}$ & $\begin{array}{l}\text { Do. } \\
\text { Do. }\end{array}$ \\
\hline 16. & 1 & 1,800 & $\begin{array}{l}4 \\
4\end{array}$ & s.... do............ & $\begin{array}{l}14.50 \\
14.50\end{array}$ & Do. \\
\hline 17. & 11 & 4,000 & 5 & Furnace............... & 22.50 & Do. \\
\hline \multicolumn{7}{|c|}{ 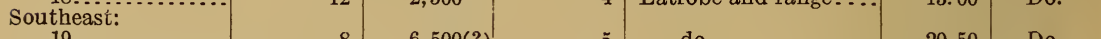 } \\
\hline & 8 & $6,500(?)$ & $\tilde{5}$ & .....do. & 20.50 & Do. \\
\hline $20 .$. & 7 & 3,500 & 5 & ..... do... & $\begin{array}{l}21.50 \\
23.50\end{array}$ & Do. \\
\hline 21. & 13 & 2,500 & 5 & Furnace.. & $\begin{array}{l}20.50 \\
23.50\end{array}$ & Do. \\
\hline \multicolumn{7}{|l|}{$\begin{array}{r}22 \ldots \ldots \\
\text { Southwest: }\end{array}$} \\
\hline $\begin{array}{l}23 . \ldots \ldots \\
24 \\
25 . \ldots\end{array}$ & $\begin{array}{l}7 \\
8 \\
5\end{array}$ & $\begin{array}{l}2,500 \\
2,500 \\
1,600\end{array}$ & $\begin{array}{l}4 \\
4 \\
4\end{array}$ & $\begin{array}{l}\text { Latrobe and range } \\
\ldots \ldots \text { do } \ldots \ldots \\
\ldots \ldots \text { do } \ldots\end{array}$ & $\begin{array}{l}15.50 \\
15.50 \\
15.00\end{array}$ & $\begin{array}{l}\text { Colored. } \\
\text { Do. } \\
\text { Do. }\end{array}$ \\
\hline
\end{tabular}

But how many of these 227 two-flat houses are occupied by the families of laboring men? The following: Groups 12, 23, 24, and $25-24$ houses, or only 48 families. Groups 13, 14, 15, 16, and 18 are occupied by wage-earners, such as street-car conductors, motormen, policemen, and the like. The fact is that while these dwellings have been provided, they are so few that they are at once occupied by thrifty people who take advantage of the moderate rentals, and, being good tenants, are given preference over the day-laborer class. Thus the alley and shack dweller continues to live in his miserable surroundings, waiting until time and natural decay will have reduced the new dwellings of to-day to his rental level or until some happy day when there may be enough good homes " to go around."

\section{RENTS IN THE SUBURBS.}

No statistical information can be given about the rent situation in the suburbs. In the first place, only a few of the laboring people live 
outside the city, usually only those required for the labor customarily going on in their vicinity. Those engaged in labor in the city can not live in the suburbs, because of loss of time in getting to and from work, cost of car fare, and distance from market.

Rents are high, however, for the few laboring men who do live in the suburbs. A five-room house without any internal improvements brings $\$ 10$; a somewhat larger house of the same sort, with a hydrant in the yard, brings $\$ 15$. Two, three, and four room shacks bring $\$ 6$, $\$ 8$, and $\$ 10$ rent; and even the craziest patchwork of a structure of one room may rent for $\$ 5$.

Houses of the cottage type described elsewhere are most frequently owned by wage-earners of the mechanic class, but, when rented, the rentals do not much fall below the city standard. In Brookland, Brightwood, Takoma Park, and communities of that sort, six and seven room cottages rent for $\$ 22.50$ and above; farther out and in less improved localities, where there are no sewers or sidewalks, the same quality of house brings $\$ 18$ or $\$ 20$ rent. The same rents prevail in whichever direction one goes. The tendency in the suburbs is toward ownership; new buildings are not constructed to rent, because winter drives the people to the city unless anchored on their own property. Rented property consists of " remnants," as a rule, and, as in the city, the rule for renting seems to be: "Charge every cent the traffic will bear."

H. C. Macatee.

RENTS IN ENGLAND.

Rents are considerably lower in England than in this country. But it should be remembered that wages, and consequently the cost of building, are also lower.

Mr. William Thompson, in the Housing Handbook, says:

Four years ago Mr. F. Lawrence, of Mansfield House University Settlement, ascertained the following accommodation and rents to rule for trade unionists in the respective large provincial towns: Bristol, 6s. 6d. for five rooms and scullery; Hereford, 5s. 6d. for four rooms and scullery; Birmingham, 5s. to $6 \mathrm{~s}$. for five rooms and scullery; Derbs, $4 \mathrm{~s}$. $6 \mathrm{~d}$. to $6 \mathrm{~s}$. for six rooms; Sheffield, $4 \mathrm{~s}$. $6 \mathrm{~d}$. to $6 \mathrm{~s}$. for four rooms; Leeds, $4 \mathrm{~s}$. $6 \mathrm{~d}$. to $5 \mathrm{~s}$. 6d. for three rooms, scullery, and cellar; Bradford, $4 \mathrm{~s}$. to $7 \mathrm{~s} .$, with an arerage of $5 \mathrm{~s}$. for three rooms and scullery; Rochdale, $4 \mathrm{~s} .6 \mathrm{~d}$. to $5 \mathrm{~s}$. $6 \mathrm{~d}$. for four rooms; and IIanchester and Salford, 5s. 6d. to $7 \mathrm{~s}$. for four rooms and scullery.

In suburban districts outside London the present tendency is for two families to occupy an ordinary six-roomed house and to pay from $6 \mathrm{~s}$. to $8 \mathrm{~s}$. or an arerage of about $7 \mathrm{~s}$. $6 \mathrm{~d}$., for three rooms.

WHAT SHOULD BE THE STANDARD RENT FOR MUNICIPAL DWELLINGS.

But supposing the looked-for improvement in the porrer of authorities and the other adrantages referred to above were realized. With lengthened loan periods, lowered interest, simpler sanitation, and rural sites, with correspondingly low rates, the expenditure will drop to a minimum, so that the rents charged may be lowered below those charged for the same accommodation by the private speculator. Even then the difficulty will be to so fix the rents that all the working classes can pay them; indeed it must be acknowledged from the outset that the subsistence wage of the poor unskilled morker is not sufficient to allow him to pay the mere interest on the bricks and mortar that must form his dwelling. Under present circumstances it is almost impossible to house the very poor in really healthy homes so as to make a commercial profit. The raising of the standard of buiding and the enforcement of structural sanitation by model by-laws, have, while making the houses more habitable, added considerably to overcrowding, and every act of the sanitary reformer will make this problem of housing the very poor more acute. The lowest classes can not 
afford to pay any interest at all or any sinking fund, and the community may find it more profitable to house these people at a merely nominal sum than to allow the present wasteful system to continue-a system that destroys health and life and also demands that wor'st form of all help, viz, poor relief.

To sum up, it may be said that the following inclusive weekly rents per room in cottage dwellings would be about as fair and reasonable as could be expected:

Rent per room per week.

Rural rillages $6 d$.

Small urban districts

Large urban districts $9 d$.

Large towns $1 \mathrm{~s}$.

London suburbs 1 s. $3 d$.

The efforts of housing reformers should be directed toward securing such reforms as will facilitate the erection of a large number of these dwellings in rillages and small towns and on the outskirts of large towns and cities.

The author above quoted gives the cost of building, per room, as $£ 40$ to $£ 60$ in London and as $£ 30$ to $£ 40$ in Liverpool. This is somewhat less than the cost of building in Washington, which may be given as from $\$ 300$ to $\$ 350$ per room, including a bathroom for each three or four room apartment. The rent, to cover all expenses of maintenance and pay a dividend of 5 per cent on the capital invested should be from $\$ 3$ to $\$ 4$ per month per room, according to location and cost of land. It appears that in England, and especially in Scotland, a considerable proportion of the laboring population is housed in one or two room houses or apartments. Investigations made in the city of TYashington show that, as a rule, our day laborers consider a separate "sitting room" essential, not so much to comfort as to respectability. They are willing to use the smallest kitchen as a dining room, or even as a bedroom, but, unless absolutely compelled to do so, will not put a bed in the front room, in which they receive their visitors. They therefore require apartments of at least three rooms. This is an unnecessary extravagance where there are but two in the family, as in the case of newly married couples and old people without children. There are but few two-room apartments available in the city of Washington. The Sanitary Housing Company built 10 houses on $\mathrm{H}$ street SW. in 1906, containing 20 independent tworoom apartments, each one being provided with a bathroom and back yard. These are rented to white tenants. Experience shows that three and four room apartments are in greater demand, and vacancies are not infrequent in the two-room apartments. It may be that the lower rentals would make them more popular with colored tenants. The cost of an additional room need not add more than $\$ 2$ a month to the rent, as the two-room apartments require the same plumbing and the cost of brick walls, roof, floors, etc., is not increased by onethird when an additional room is given.

In New York City, as would be expected, rents are considerably higher than in Washington, and, owing to the high price of land, the poorer classes of the community are obliged to live in tenement houses of from three to six stories in height. The report of the tenement-house department for 1906 shows that in tenement houses constructed under the new law the prevailing type provides for apartments of four rooms, with private bath. Such apartments are probably quite beyond the reach of unskilled day laborers. The cost of shelter in the older tenement houses on the lower East Side of Man- 
hattan is shown by the following extract from a paper by Charles Z. Bernheimer (Charities and Corrections, January 18. 1908, p. 1404) :

Three-room apartments in a tenement on Orchard street which rented for $\$ 10$ in 1902 now rent for $\$ 14$. Those which rented for $\$ 11.50$ in 1902 now rent for $\$ 14.50$. Some which were $\$ 12$ in 1902 are now $\$ 14$ or $\$ 15$. That is to sas, the rise has been from $\$ 2$ to $\$ 4$ per apartment. This rise is characteristic of rentals all over the lower East Side. It is true of a number of houses which I investigated in one block. Be it remembered, too, that these houses are oldlaw, unimprored tenements.

The block investigated by me, with the aid of another resident of the Unirersity settlement, James P. Kranz, is bounded by Allen, Stanton, Orchard, and Rivington streets. It does not differ materially from other blocks in the neighborhood, although it is one of the most crowded.

There are about 500 apartments in the block. We made inquiries of families in 343. The families were Jews from Russia, Roumania, and Galicia. The average residence in the United States for the head of the family mas a little over seren years, and the average tenancy of the apartments mas a trifle more than two years.

The rental on the average was as follows:

Two-room apartments $\quad$ Per month.

Three-room apartments _.

Four-room apartments

Fire-room apartments

The average per room was $\$ 4.63$ a month. The rental of the entire number of apartments averaged $\$ 14.55$ a month, or $\$ 174.60$ a vear.

Then it is considered that the arerage income of families in the block was about $\$ 600$ a year, it can be readily understood how difficult the situation is. This nieans that on the arerage 30 per cent of the income goes for rent. Every increase reduces the amount arailable for food and other necessities.

It will be noted that these rents in the "old-law unimproved tenements " of New York are considerably above those paid by tenants of the Washington Sanitary Housing Company for apartments provided with a bath, which the New York tenement-house apartments, above referred to, presumably are not.

In the third annual report of the tenement house department of New York City we find the following remarks with reference to bathing facilities:

Before the enactment of the present law, the majority of the new tenement houses were provided with no bathing facilities whaterer. The omission of these facilities now, howerer, is exceptional. Indeed they hare come to be recognized as a necessity.

Of the 475 buildings planned in 1906 , 356, or 74.47 per cent, have bath accommodations in each apartment; 64 , or 13.47 per cent, have such accommodations provided in some apartments, but not in all; and 55, or 11.58 per cent, are entirely without them. The, increase in the number of buildings having no bath accommodations is due to the increase in the number of houses erected for certain elements of the foreign-born population. These buildings, generally five and six stories in height and arranged for the use of five and six families on each floor, are constructed in the most economical manner for the purpose of reducing the rental for apartments to the lorrest possible figure.

Mr. Thompson, in The Housing Handbook, remarks:

The double-decker tenement houses of New York and Chicago are dearer and more deadly than London slums, while the working class suburban streets are badly pared, if at all, and lined with houses of cheap anc inferior construction, having possibly another row of small houses on the sites of what ought to be their back gardens. Rents of from 3s. to 6s. per room per week are by no means uncommon.

Taking the figures for 1891 at random, it will be found that Berlin had no less than 367,000 families in 21,600 buildings, or an arerage of 17 families 
under one roof, not one family in 600 having a house of their own. The cellar dwellings of German cities varied from 36,542 , or $6 \frac{1}{2}$ per cent of the population in Hamburg, to 117,702 , or $7 \frac{2}{3}$ per cent in Berlin. In Breslau, Dresden, and Magdeburg nearly half the population live in one-roomed dwellings, if we do not count a small closet or half-room called a "zubehör," which is a characteristic part of most German dwellings, and is not provided with any fireplace for warming or rentilation. Rents on an average take close upon one-third of the wages. The people of Paris live 30 to a house on the average, and in spite of the millions spent on improvements have a death rate higher than that of London.

For the purposes of this report a special investigation has been made in the cities of Baltimore and Philadelphia to ascertain the types of houses now being built for the laboring classes and the rents paid, especially by unskilled workmen. These cities have been selected because climatic and other conditions_are similar to those which obtain in Washington, and there is a tendency in both cities to provide independent homes for the working classes, rather than to house them in tenement houses of three or more stories.

It was pointed out in the section of this report entitled "The house famine" that there had been found within this city only seven brick dwellings, erected in the past five years, which could be rented for less than $\$ 15$ per month. In striking contrast with this condition, it was found that in Baltimore the average rate of rent for a new six-room, furnace-heated house is $\$ 13$ per month. Such a dwelling has been described in Section III. For purposes of comparison, it may be said that this is the type of dwelling which in this city commands rentals of $\$ 20$ and above. In addition to this type, there are in Baltimore very many four and five room houses, provided with running water, which can be rented for $\$ 7$ per month; the same type of house, with a bath added, can be had for $\$ 9$ or $\$ 10$ per month.

In Philadelphia the best types of new six-room dwellings are provided in great numbers at rentals of from $\$ 13$ to $\$ 16$ per month. These houses would bring from $\$ 25$ to $\$ 30$ in Washington. Four and five room houses, of a better type than those in Baltimore, can be had for $\$ 10$ and $\$ 12$ per month. In both cities the dwellings here spoken of are new, or of comparatively recent construction, and they are entirely eligible from a sanitary standpoint. The striking difference between Washington and her two neighbors lies not so much in difference in types of dwellings, but in rents charged. We find negroes and poor whites living in such miserable habitations here that the creation of this commission was considered necessary. They are paying for these same dwelling places rents equal to those paid for new and sanitary six-room dwellings in Baltimore and Philadelphia.

It is true that these houses in the cities named do not house the day laborer class, and it may be true that the day laborers in those cities find difficulty in securing homes within their means; but if this be true, it merely emphasizes the fact that in Washington the rents are enormously above the means of the poorer people, and that, after the rents are paid, they do not therewith secure proper habitations.

\section{PRINCIPLES OF ECONOMIC CONSTRUCTION.}

It is hardly necessary to say that an individual or a company can build a considerable number of houses, in a block, or as separate cottages, more economically than a single house or a few houses can be 
built. A contractor can afford to figure upon a smaller percentage of profit on a large job than he would be justified in taking on a small one, and he can purchase materials on a large scale at lower prices than for small quantities. The private individual of small means is therefore at a disadvantage as compared with the man of wealth or a corporation with ample capital. It is a great advantage in building small houses for the laboring classes to be able to control and subdivide city squares or suburban properties to the best advantage. Where houses are to be built in blocks long and narrow lots are a decided disadvantage, as the lighting of interior rooms is one of the principal problems to be solved. The nearer a house approaches the

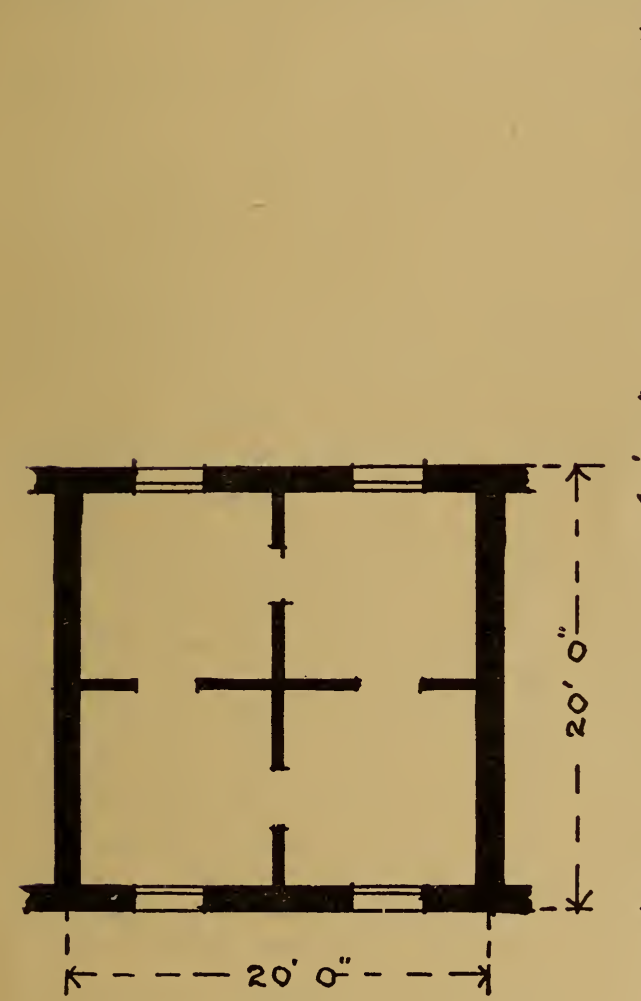

Frg. 37.

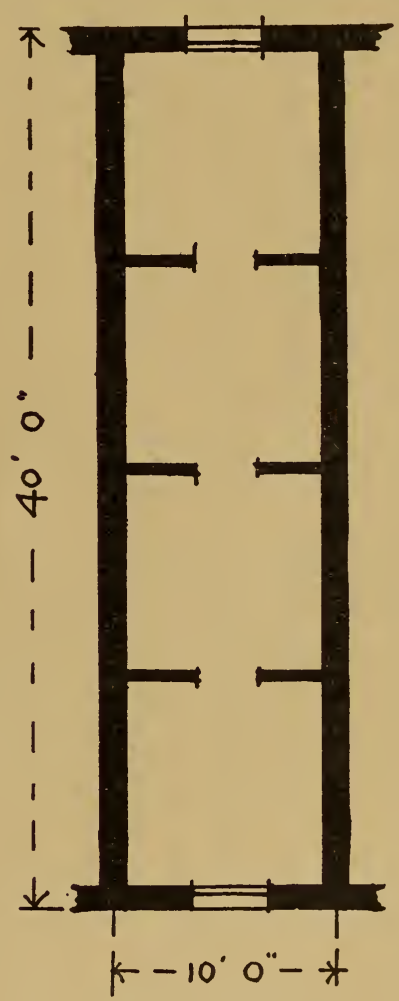

FIG. 38.

form of a square the more economical it will be in construction. This will be apparent from the following figures representing two houses having the same floor space, viz., 400 square feet. In the one case (figure 37 ) the dimensions are 20 by 20 feet, and it is evident that the four walls inclosing this area require to be 80 linear feet in dimensions. In figure 38 , with the same floor area, the walls inclosing this space must be 100 feet in length. It is also apparent that any cut in one of these rectangular figures, for the purpose of lighting interior rooms, will diminish the floor area and increase the number of linear feet of wall required. If figure 37 represents a house in a block, we may divide it into four rooms, each 10 feet square, and each room can have one or more outside windows. Figure 38 may also be divided 
into four rooms, each 10 feet square; but in a block of similar houses two of these rooms will be entirely dark. When it is necessary to build upon long and narrow lots the main problem from a hygienic and economical point of view is how to give sufficient light and ventilation to these interior rooms. To utilize the land in an economical manner it is necessary to build as many houses on a given frontage as the building regulations permit. Formerly many houses were built in the city of Washington on lots having 12 feet frontage. But under existing regulations 16 feet is the minimum width of a lot permitted. Within the fire limits of the city only brick houses can be built, and these must have walls 13 inches thick. If we propose to light the interior rooms in figure 38 from the rear of the house by an open court, we reduce the dimensions of the two back rooms by five feet, as the regulations require a court to be at least five feet in width. When the depth of the court is more than 20 feet, in the house with four rooms in one line, it will be necessary to provide also for a bathroom facing the court, and this will make a court of more than 20 feet. Add to this the thickness of the walls (9 inches on court and one-half of 13 inches for the party wall), and we find that on a 16-foot lot the width of our two rear rooms is reduced to 9 feet $8 \frac{1}{2}$ inches. If a hallway is provided to pass from the front room to the rear of room of the house this will further reduce the width of one of these court rooms by at least 3 feet, making it too narrow to serve either as a bedroom or as a kitchen. It will, therefore, be necessary to pass through a bedroom to reach the kitchen, or through the kitchen to a bedroom in rear of the house. Passing through the kitchen will be the least objectionable, and it is desirable to have this kitchen near the middle of the house, so that adjoining rooms may be heated in winter by the kitchen range. Experience shows that in three and even in four room houses tenants usually do not require any more heat than is furnished by the kitchen stove. Another way to light the interior rooms, which does not diminish the floor area of any of the rooms, is by means of a light shaft, which, under existing regulations, must not be less than 8 feet square. This, of course, must come between the two interior rooms, and it adds 8 feet to the depth of the house. Upon a deep and narrow lot (80 to 100 feet) this addition to the depth of the house still leaves a good-sized yard in the rear. A light shaft having the required dimensions gives ample light to the upstairs apartment. It should be whitewashed or painted white, in order that the first-floor apartments may be sufficiently lighted. The advantages of building upon shallower lots, having a wider frontage, are apparent, and for this reason the problem of economic building is much simpler when a city square can be subdivided for the special purpose of building upon it houses of small cost for occupancy by workingmen. The Washington Sanitary Improvement Company has recently purchased a city square in southwest Washington, and has subdivided it, as shown in the diagram (fig. 39).

The original subdivision of square 651 is shown in figure 10 . The objectionable alley houses of Washington have been built upon "blind alleys" such as are shown in this diagram.

The lots in this subdivision cost the company about $\$ 350$ each. Houses are being built upon these lots which have a frontage of 20 feet, according to the plans and specifications given on pages 43 to 53 
of this report. It will be seen that every room in these houses has an outside window, and that there are no courts or projections of any kind to add to the expense of construction. Bay windows, ornamental cornices, front porches, etc., would add to the attractiveness of these houses, but not to the comfort of the occupants, and the object in view is to give the tenants the lowest possible rents consistent with safe business management and the payment of 5 per cent dividends to the capital invested. In considering economic construction the elements of durability and cost of repairs must be taken into account. It is economical in the long run to use materials of good quality. Good foundations are essential and are required by the building regulations. A slate course to prevent dampness of walls is now considered essential. The first floor should be at least 18 inches above the ground, and free ventilation of the space beneath this floor should be provided for. Double floors are desirable, both for the first and second story. The Sanitary Improvement Company some years since gave up the practice of painting interior woodwork. Instead of this the woodwork (Georgia pine) is oiled or varnished. Everyone is pleased with the change. Painted woodwork soon gets dirty, especially where there are children in the house, and repainting at frequent intervals is a considerable item of expense. The walls of stairways and the lower half of the kitchen walls had better be plastered with cement mortar. This is less liable to be broken and is probably more economical in the long run. Tin roofs require frequent painting and repairs. The experience of the Sanitary Improvement Company is in favor of slag roofs. They cost less in the first instance and appear to be more durable.

The Sanitary Housing Company has used cement blocks for the fronts of 20 houses built in 1906 on M street SW. The cost was about the same as for hard brick. The appearance of the houses is quite satisfactory, and this material will probably be largely used in many sections of the country. In Washington sand has to be brought some distance, and cement construction is dearer than in some other localities. For this reason it is doubtful whether Edison's plan of building cheap houses for the poor by filling a complete mold of the house with cement can be profitably employed here, even if it proves successful elsewhere. There is no economy in poor plumbing, but bathroom fixtures can be substantial and durable without being expensive. Mantelpieces and fancy wall paper do not add to a tenant's comfort, but do add to the rent he must pay. However, they add to the attractiveness of a house, and the poorest tenants are often willing: to pay for such things, even if they can not afford them. The Sanitary Improvement Company and the Sanitary Housing Company find that their apartments are in great demand, although the rooms are not papered. The tenants, however, often paper them at their own expense.

The greatest possible economy in construction calls for a perfectly plain front, such as is shown in the block of houses on Van street (fig. 9). The monotony of this type may be relieved by a more or less ornamental cornice, by bay- windows and front porches, as shown in figure 10, or by such a projection as is shown in figure 11. This lattei plan gives a covered entry for the lower apartments in these two-story flats. The upper flats of two adjoining houses have each 
one-half of this projection as a bay window. The entrance doors of two upstairs flats are seen between these projections. Inside these doors there is a small vestibule at the foot of the stairs leading to the apartment above.

These and other exterior additions or decorations may add to the value of a "home" from an rsthetic point of view, but all such additions will, of course, make it necessary to increase the rents, and will

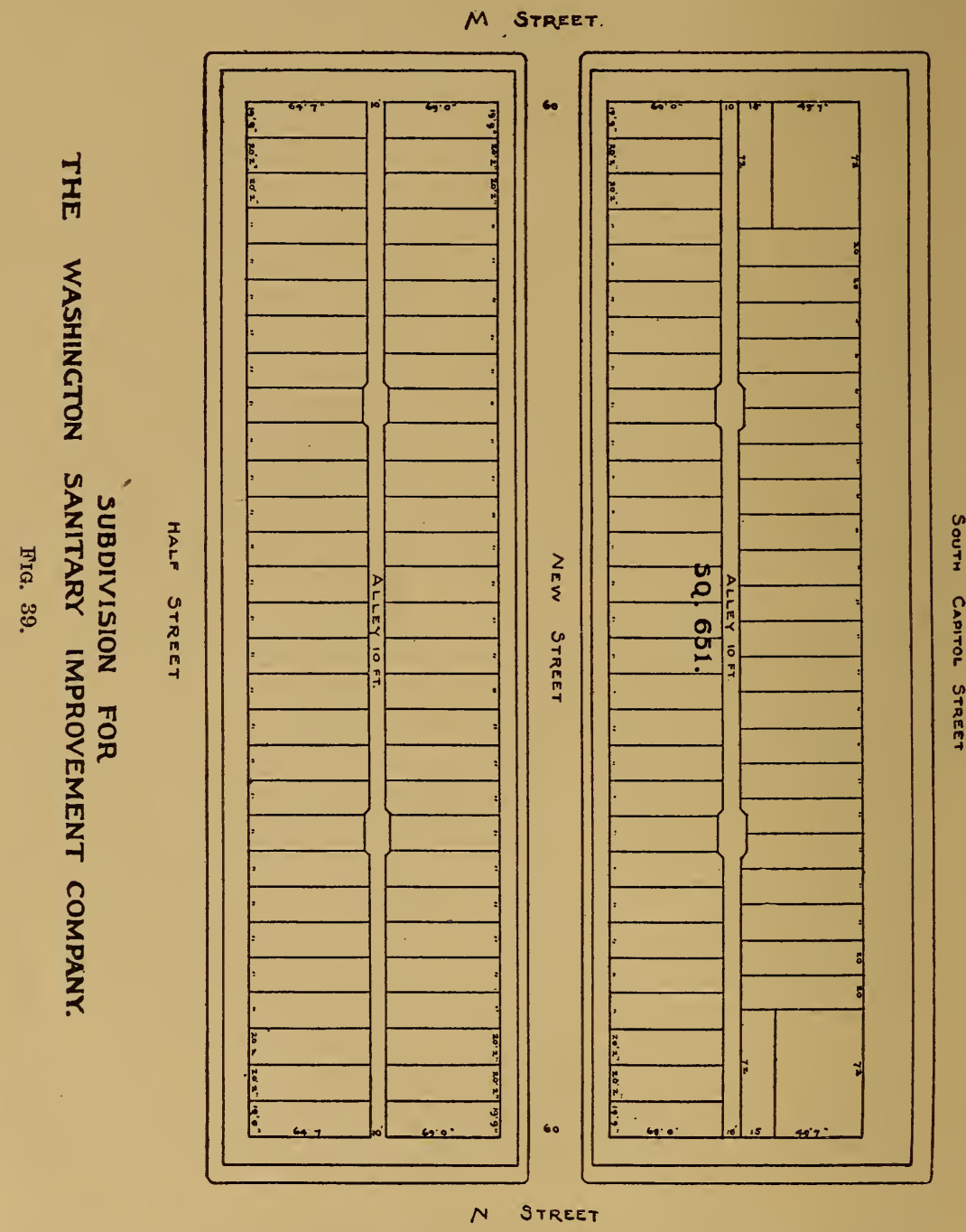

make the houses unavailable for the lowest class of wage-earners. It is evident that the most economical method of construction, for a given floor space, is that obtained by building tenements of several stories, covered by a single roof, and having stairways, hallways, and toilet facilities in common for two or more families. Where ground is expensive, as in the large cities of this country and Europe, there seems to be no method of getting away from this type of " tenement 
house." The best that can be done my municipal authorities where houses of this type are being built to supply the demand for two, three, and four room apartments, renting at figures which bring them within the reach of unskilled workmen, is to enforce suitable regulations as to dimensions of rooms, light, ventilation, width of stairs and hallways, toilet facilities, etc. But such tenement houses are objectionable

M STREeT.

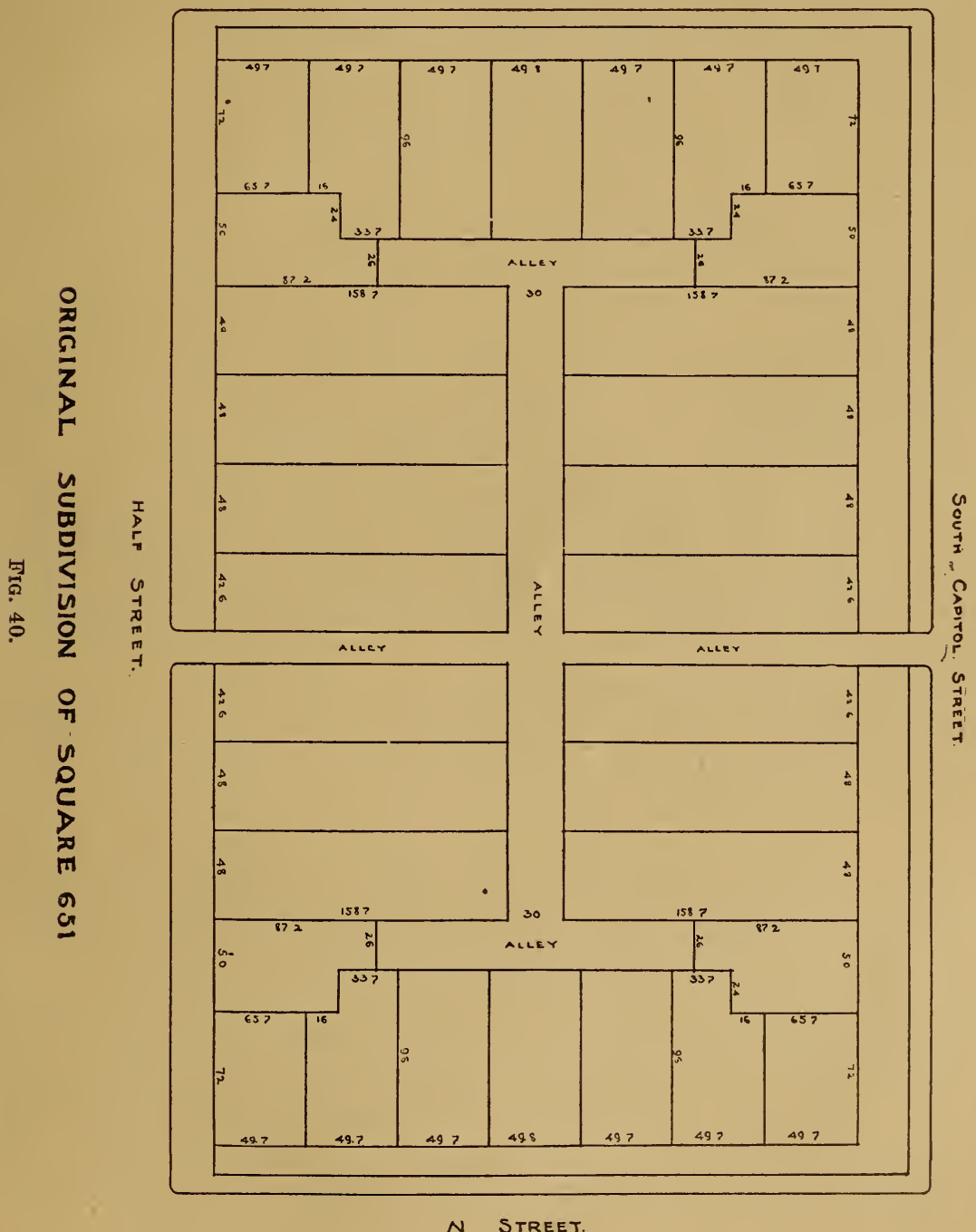

under the best methods of construction and management. When provided with elevators, janitor service, and bathrooms for each apartment, they are no longer classed as tenement houses, and may be made in every way desirable for occupancy by the better classes of wageearners. It is unnecessary to dwell upon the evils of tenement-house 
life as it exists in New York and other large cities. Fortunately, land is so cheap in certain parts of Washington and in the suburbs that we have, to a great extent, escaped these evils. And it is to be hoped that the new building regulations, soon to be issued, will provide against the construction in future of tenement houses of this type. In planning houses for the Sanitary Improvement Company, more than ten years ago, the writer had in view the desirability of furnishing each tenant a separate home, having nothing in common with any other family. But a separate house upon a city lot having a frontage of 16 feet would cost too much to bring it within the reach of an unskilled laborer, or even of a skilled mechanic, or a clerk having a large family and a small salary. Two houses can not be placed side by side upon a 16 or even a 20 foot lot, but two independent homes can be corered by a single roof on such a lot. This entirely removes the tenement-house features and appears to be the most practical method of providing independent apartments, at low rentals, within the city limits. In the suburbs separate frame houses may probably be built upon larger lots to rent at about the same price as it is necessary to ask for one of these apartments. In the two-flat houses above referred to the back yard is divided into two parts by a high board fence, so that each family has an independent yard leading to an alley in the rear. The houses of the Washington Sanitary Improvement Company also have, as a. rule, a cellar, with cement floor, for each apartment. The back stairway for the upstairs apartment is usually constructed in connection with a back porch, but in some cases an inside stairway leads to the back yard. This, of course, diminishes the width of the rear rooms of the lower flat to the extent of the width of the stairway. (See fig. 35.) The back porches are highly appreciated, and the upper flats provided with these porches readily rent for 50 cents per month more than lower flats in the same house.

At present prices of material and labor, the cost of the construction of houses of this type will be from $\$ 350$ to $\$ 400$ per room, including cost of bathroom, back porches, yard fences, sidewalks, etc.

\section{PRINCIPLES OF ECONOMIC MANAGEMENT.}

The economic management of dwellings constructed for the poorer classes of the community calls for special care. The cost of such management will, of course, constitute an important item in the amount of rent which must be paid by the tenants; for, as a rule, such properties will be required to pay a reasonable rate of interest on the capital invested. At the same time provision must be made for the deterioration resulting from wear and natural decay. The average "life" of houses of this class, built of brick, in accordance with modern building regulations, may be placed at about fifty years, and, from a business point of view, it will be necessary to fix rentals at such a rate that a surplus of from 1 to 2 per cent will remain after paying a reasonable interest on the capital invested and all expenses of management. This will be necessary even in the case of corporations organized from philanthropic motives, for experience shows such corporations can not obtain the money required for extensive operations unless their stock is regarded by those who have money to invest as a safe dividend-paying investment. Small subscriptions may be obtained by personal solicitation to inaugurate a movement for the betterment of housing conditions, 
but such efforts will not lead to important results unless it can be shown that the investment is safe from a business point of view. This was recognized at the outset by the writer and his associates when the Washington Sanitary Improvement Company was organized in 1897. The dividends were limited by the by-laws of the company to 5 per cent, and rentals were fixed at such a rate as would pay these dividends and the cost of management, and at the same time afford a surplus to provide for the gradual deterioration of the buildings. At the outset it was difficult to secure subscriptions to the stock of the company, but when, at the end of three or four years, the demonstration had been made that the stock of this company was a safe 5 per cent investment, subscriptions came in more rapidly and without any special effort on the part of the directors. This is shown by the following:

Statement showing grouth of the Washington Sanitary Improvement Company and its surplus earnings.

\begin{tabular}{|c|c|c|c|c|c|}
\hline April 1- & Assets. & $\begin{array}{l}\text { Surplus } \\
\text { fund. }\end{array}$ & April 1- & Assets. & $\begin{array}{l}\text { Surplus } \\
\text { fund. }\end{array}$ \\
\hline $\begin{array}{l}1898 \ldots \ldots \\
1899 \\
1900 \\
1901 \\
1902 \ldots \ldots \ldots\end{array}$ & $\begin{array}{r}\$ 35,959.05 \\
47,952.17 \\
76,123.79 \\
138,344.22 \\
265,668.59 \\
382,538.63\end{array}$ & $\begin{array}{r}\$ 484.88 \\
1,961.43 \\
4,672.76 \\
8,326.02 \\
15,555.38\end{array}$ & 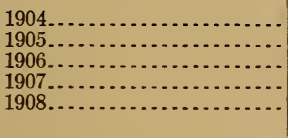 & $\begin{array}{r}\$ 427,910.00 \\
494,663.58 \\
674,265.97 \\
704,033.41 \\
711,720.81\end{array}$ & $\begin{array}{r}\$ 33,371.44 \\
43,328.86 \\
55,057.24 \\
74,233.41 \\
93,320.81\end{array}$ \\
\hline
\end{tabular}

The capital stock of this company is limited by its charter to $\$ 500,000$, but by investing its surplus in houses and by borrowing money upon its real estate it has been able to increase its usefulness, and the assets of the company now amount to $\$ 711,720.81$, with an

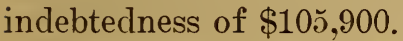

The company now owns 200 houses of the two-flat type described in a previous chapter, and is building 29 more houses for colored tenants in the southwest section of the city. (See Sec. III, p. 19.)

The Sanitary Housing Company, which was organized in 1904, also has an authorized capital of $\$ 500,000$. This company is incorporated by an act of Congress, and its dividends are limited by its charter to 4 per cent. The object in thus limiting the dividends was to give the humbler class of wage-earners sanitary homes at rentals which they could afford to pay. This company has been quite as successful as the other in paying its dividends and earning a surplus. But, in the present state of the money market, it is difficult to obtain subscriptions to the stock of a 4 per cent company, and it is unable at present to continue its building operations. The present state of its finances is shown below:

Statement showing growth of the Washington Sanitary Housing Company and its surplus earnings.

\begin{tabular}{|c|c|c|}
\hline May 1- & Assets. & Surplus. \\
\hline $\begin{array}{l}1905 \ldots \\
1906 \ldots \\
1907 \ldots \\
1908 \ldots\end{array}$ & $\begin{array}{r}\$ 45,463.91 \\
47,095.43 \\
68,288.05 \\
96,939.35\end{array}$ & $\begin{array}{r}\$ 139.09 \\
1,211.18 \\
1,846.16 \\
3,872.80\end{array}$ \\
\hline
\end{tabular}


The writer feels that it is proper in this report to give brief details of the operations of these companies, which were organized for the express purpose of assisting in the relief of the "house famine" in the city of Washington, for the purpose of showing what can be done under careful management and as an incentive to individuals and other organizations to aid in this work. The complete relief of the situation, which has been fully set forth in other sections of this report, will require considerable time and will call for the expenditure of large sums of money. What can be accomplished by organized effort has been shown. The question now is, Where is the money to come from to carry on the work?

Economic management calls, in the first instance, for a system of oversight and rent collection which shall prevent, so far as may be, losses from vacancies or from failure to collect. In order that the loss from vacancies may be reduced to a minimum it is necessary to give tenants attractive and desirable flats or houses at rentals within their means, and at least as low as can be obtained elsewhere. There is no profit, in the long run, in putting rents up to the limit and in neglecting to make necessary repairs. It is far better to receive a reasonable rent all the time than to demand an excessive rent and have a house vacant half the time. The flats of the two companies heretofore referred to are always in demand, and there is usually a waiting list of those who desire to secure one of them when a vacancy occurs. Many vacancies occur, under indifferent management, because the landlord declines to make repairs deemed necessary by the tenant. The companies above referred to avoid this by their rebate system. Under this system, which was adopted at the outset of the enterprise, one month's rent in each year is devoted to interior repairs, and if no repairs are needed a rebate is made of the entire month's rent. The tenant has thus a special inducement to take care of his flat, and when repairs are needed he has the choice of making them himself or of reporting them to the agent, who has them made and charges the cost against the rebate. The tenant certifies in the bill that the repairs have been made and are satisfactory. At the end of eleven months the agent inspects the flat and causes all necessary repairs to be made; whatever balance remains after paying for these repairs constitutes the rebate to be deducted from the twelfth month's rent. This method insures excellent care of the premises, as it is in the interest of the tenant to make the bill for repairs as low as possible, because it comes out of his "rebate." On the other hand, the agent of the company insists that all repairs must be made before the balance, if any, from the twelfth month's rent is paid to the tenant.

Quite a number of the tenants occupying these flats have kept their apartments in such repair that they are entitled every year to the full rebate of one month's rent, and many have taken so much pride in their homes that they have expended the rebate, and often more, in papering the rooms or in other improvements. Many of the tenants have occupied their apartments for several years. Even among the colored tenants on Van street there are several who have held their flats since the completion of the buildings in 1904. Another feature which has proved most valuable has been the plan adopted of having the agent of the company live in one of the flats 
and a subagent in each detached block of houses. This enables wageearners to transact all business connected with the renting, paying rent, etc., without losing any time, as the agents attend to such business after working hours. Moreover, the agent and subagents have a personal interest in having respectable people as their neighbors, and they are always on hand to look after the property and give good advice as to caretaking. Rents are collected monthly in advance, and must be paid; for, while the objects of the company are philanthropic, its management is conducted upon strict business principles.

Not only must rents be paid, but tenants, no matter how humble, must belong to the respectable and industrious class of the community. References are required in advance, and disorderly or immoral persons, if they succeed in obtaining a flat, are notified to leave as soon as the agent discovers that they are undesirable tenants. The provisions of the lease which enable the company to obtain possession on short notice are given below:

\section{THIS AGREEMENT,}

Made this ___ day of __ 190 - between —_, as agent for the Washington Sanitary Housing Company, of the first part, and - , of the second part, all of the city of Washington, D. C., whereby the party of the first part has let, and does hereby let, to the said party of the second part the premises known as - in said city (the same being an apartment) by the month, commencing on the 1st day of - , A. D. 190-, at and for the monthly rent of - dollars, payable in advance; that is to say, on said first day of each and every month during said tenancy as rent in advance for the next ensuing month.

And the said party of the second part has agreed to take, and does hereby, take and hold the said premises as tenant by the month, at the said rent, payable as aforesaid, and that he will not sublet or assign the said premises, or any part thereof, or carry on any business therein, without the written consent of the said lessor, his successor or assigns, or use the same for any disorderly or unlawful purpose.

Provided, that if the said lessee shall fail to pay the said rent in advance as aforesaid, although there should hare been no legal or formal demand for the same, or shall sublet or assign the said premises, or any part thereof, or carry on any business therein, without the written consent as aforesaid; or shall use the same for any disorderly or unlawful purpose, or break either of the aforesaid covenants, then, and in either of said events, this agreement and all things herein contained shall cease and determine, and shall operate as a notice to quit, the thirty days' notice to quit being hereby expressly waived. And the said lessor, his successors and assigns, shall and may proceed to recover possession of said premises under the provisions of the code of law for the District of Columbia to regulate proceedings in cases between landlord and tenants, or by such legal process as may at the time be in operation in like cases; but if no default occurs on the part of said lessee, then he shall be entitled to not less than three days' notice to vacate the apartment and premises, which notice shall be given in writing, at least three days before said tenancy is intended to be terminated, and the said lessor, his successors and assigns, shall be entitled to the same notice from the lessee should he desire to vacate the aforesaid house and premises.

It is also provided, that inasmuch as the Washington Sanitary Housing Company, owner of the property herein described, has for its object the improvement of the sanitary conditions of dwellings and tenements in Washington City, and inasmuch as the right to send representatives of said company to inspect the herein-described premises is necessary in order to carry out this object, it is mutually agreed that said representatives shall have the right to inspect said premises, or any part thereof, at such times as in their opinion may be necessary; and the said party of the second part agrees that the property hereby rented shall be used in a careful manner, that it will be kept free from all unsanitary conditions; that no dogs, pigeons, chickens, or other animals or fowls shall be kept within or upon said premises; that the plumbing and plumbing fixtures shall 
be used with special care, and that generally every effort will be made to assist said Washington Sanitary Housing Company to attain its object as hereinbefore stated. Any neglect or rough use of the premises described shall be considered a breach of this contract, and entitle the said party of the first part to immediate possession.

It is mutually agreed that at the end of each twelre months of this tenancy there shall be paid to the said party of the second part a sum of money equal to one installment of rent, or so much thereof as is not required for repairs; prorided, however, that each of said twelve months' rent shall have been paid promptly. "Repairs" in this connection will include all interior repairs, when considered necessary by the company's agent, whose judgment shall be considered final in the premises.

And it is further provided that if under the provisions of this agreement a seren-days' summons shall be served, and a compromise or settlement shall be made thereupon, it shall not constitute a waiver of any covenant herein contained. And that said lessee hereby agrees to deliver the house in the same order in which it was received, usual wear and tear, fire and storm excepted; and it is hereby agreed that no waiver of one breach of any covenant herein contained shall be construed to waive or in any manner affect the covenant of this agreement.

In testimony whereof we have hereunto set our hands and seals the day and sear first hereinbefore written.

Witnesses :

[SEAL.]

The provision excluding dogs and chickens saves much trouble, as they are liable to be a nuisance to the other tenants in the same house or to those in adjoining houses.

It is apparent that when a desirable home at a low rental can be obtained only on condition of prompt payment of rent, good behavior, and careful treatment of the property, there will be a great inducement for tenants to meet these requirements.

Doctor Kober, secretary of both companies referred to above, in his History and Development of the Housing Movement in the City of Washington, D. C., says, with reference to the colored tenants of the houses on Van street:

Our tenants, all of whom belong to the class of day laborers, and some were formerly inmates of these shanties, have responded promptly to improved environments, and, under the guidance of the subagents, have taken good care of their homes. The repairs required are not greater than in the other company's houses.

In the same publication Doctor Kober refers to the death rate among the tenants of the Washington Sanitary Improvement Company as follows:

We have shown that death rates go hand in hand with bad housing conditions. In some cases the general death rate for large groups of population living in insanitary dwellings amounts to double or even treble what might be called a reasonable death rate.

On the other hand, the rital statistics of London show that the death rate "in the improved dwellings for wage-earners" is far below the general mortality of the city, and the experience of the Washington Sanitary Improvement Company is even more gratifying. During the year ending March 31, 1906, the apartments were occupied by 778 adults and 380 children; total, 1,158; births, 39 , and only 8 deaths-a death rate of about 7 per thousandwhich, with all due allowance for the average age of the occupants, shows a remarkably low mortality when compared with the general death rate among the white population, viz, 15.16 per thousand. 
It is economical to make promptly such repairs as are necessary to plumbing, roofs, etc., and to protect all exterior woodwork by two or more coats of good paint, which should be renewed at intervals of two or three years. Where a considerable number of houses are under one management, it will probably be found to be in the interest of economy to employ one or more men by the month to look after slight repairs. Competent service in the way of oversight of property, renting, and collection of rents, can, probably, not be secured for less than 5 per cent on the amount collected. This is the amount paid by the Washington Sanitary Improvement Company to its very efficient agent. If we add to this the cost of exterior repairs, taxes, water rents, and insurance, we will find that the sum total of necessary expenses is not far from 2 per cent on the capital invested. The net income should, therefore, not be less than 7 per cent, in order to pay a dividend of 5 per cent. And any amount earned in excess of 7 per cent net will count as surplus. When this surplus is invested in additional houses which also pay dividends and earn a surplus, the results will correspond with those obtained when money is placed at compound interest.

This surplus is legitimate and necessary, in view of the deterioration of property by age. In a company organized from philanthropic motives care should be taken not to allow this surplus to exceed 1 or 2 per cent annually on the capital invested. For it must come from the tenants, and a greater surplus than this would indicate that excessive rents were being charged. When a philanthropic spirit controls a business enterprise of this kind, the answer to the question as to how much rent shall be charged should depend, not upon what other houses rent for, but upon what is a fair return in interest upon the capital invested. And it is upon this basis that we must depend, chiefly, for relief from the existing house famine. Now and then a rich philanthropist may build homes for the working classes without reference to the earning capacity of the houses he builds. But sufficient capital to relieve the house famine in a great city like Washington can not be enlisted except upon the terms of a safe investment, or through the assistance of the National Government. It is hardly necessary to say that economic management requires that no officer or agent of an organization formed to build houses for the poor should receive compensation, except at most reasonable rates, for services actually rendered.

The Octavia Hill system of management, which has proved so successful in London and elsewhere, is shown by the following "notes" taken from her pamphlet, Homes of the London Poor. We quote from the Report of the Housing Committee of Birmingham (1906) :

NOTES ON MISS HILL'S SYSTEM OF RENT COLLECTING TAKEN FROM HER PAMPHLET, HOMES OF THE POOR.

1. The chief feature of Miss Hill's system is that the rents are collected by ladies; and Miss Hill gives the following reasons why ladies are so successful in this work:

(a) They are accustomed to household needs and arrangements.

(b) They are generally careful of details.

(c) The wife is the person who pays the rent, and is at home to see collectors.

S. Doc. $599,60-2-8$ 
(d) Ladies are more familiar with all that makes home comfortable for family life and children.

2. One of the principal things is "sympathy with the tenants" and a close contact with their daily lives.

3. On acquiring the control or possession of a new block of property, the houses are overhauled and repaired, and the position and character of the tenants are closely observed.

4. Tenants who will not pay rent, or who lead clearly immoral lives, are ejected. These rooms or houses which they racate are immediately cleansed, distempered, and painted. Those of the remaining tenants who show signs of or a desire for improvement, and appreciation of attention, are allowed to remove into the renovated rooms or houses, and thus each remaining room is attended to.

5. No subletting is permitted and no incoming tenants are allowed to take a decidedly insufficient quantity of rooms. The elder girls of the tenants, or older women, are employed in cleaning any passages, etc., for which the landlords are respnosible, and for this work they are paid. It is also within the authority of the landlord to insist on the cleanliness of the outhouses, staircases, etc., and also to look after the cleanliness of the rooms themselres.

6. Miss Hill has hitherto found such properties pay a very safe 4 per cent on capital inrested, and at the same time a fund for the repayment of capital is accumulating. In some cases 5 per cent is earned on the capital invested.

7. This interest is realized after spending a liberal allowance for repairs. Each property is allowed a certain amount per sear for repairs, and if this amount is not all spent the surplus is used for providing such appliances as the tenants themselres desire. It is therefore to the interest of the tenants to keep the expenditure for repairs as low as possible. This is calculated to restrain the wanton damage common among the tenants of the lower class. They are careful to aroid injury to the property, and are useful in finding economical methods of repairing, eren doing some repairs of their own accord.

8. In connection with the buildings in several neighborhoods a large assembly room has been built, or a large room set aside for gatherings, libraries, etc., and social gatherings are held there at different times for both sexes, and for young and for old.

9. Adrantage is taken during the weekly call for rent to hare a little quiet and unobtrusive conversation with the tenant, and although most landlords find a difficulty in approaching the tenants in any other way than purely as tenants, Miss Hill has, after a short time, been able to enter into the family questions and troubles, and willingly gives advice on and sympathy to all matters concerning the household.

10. All the tenants are numbered; not merely counted, but known individually, man, woman, and child. They are known at their best and at their worst.

11. The tenants are never allowed to involve themselves in debt for rent. ${ }^{a}$ Now and then they are supplied with employment to enable them to pay it, but this is in no way held before them as likely to be done, and every effort is made to develop a sense of independence.

12. Attention is paid to the children. Games and ground are in some cases provided for them, and a general interest taken in their welfare and happiness.

13. Only in extremely exceptional cases is pecuniary help given, and then only through and in cooperation with organized charity, the principle adopted

$a$ The question is often asked, How does Miss Hill manage to aroid any arrears of rent? The answer is, firm but friendly insistance generally brings the rent. When tenants find they have to pay rent for the house they live in, they bestir themselves to earn the necessary money. Miss Hill's lady assistants have many ways of helping them to do this, such as employing them to do repairs to the houses, employing the elder girls to clean the staircases, etc.; but one of the chief causes of success is that the influence brought to bear long before misfortune orertakes the tenants enables them to meet it when it comes. Miss Hill's tenants do not get into straits so easily as the tenants of those landlords who take no interest beyond collecting the rent.

It is impossible to explain in writing the thousand devices adopted by resourceful people for giving sympathetic assistance to those who require to be taught to help themselves. Suffice it to say that ladies trained by Miss Hill do succeed in collecting their rents almost in full, and this with nothing but good results for the tenants, who are also their friends. 
being that it is infinitely better to give work than either money or goocis, and it being most important that the manager should not be an almoner.

14. Each tenant is treated as a man or woman with their own view of life, and is left free to fulfill such views, the aim of the worker being rather to bring a man or woman to a point of considering and judging right.

15. One of the results of this work is that instead of being met on the doorstep with a rent book and half a week's rent, with further entry denied, a warmer welcome is extended to the collector of the rent, who naturally enters the room and in nine times out of ten sits down for a little chat.

The result of Miss Hill's method is that landlords are continually giving her more property to manage (the ecclesiastical commissioners handed orer to her a sear or two ago a further 22 acres of houses), and tenants are always on the lookout for "houses under the ladies."

\section{x. CONCLCSIONS.}

We accept the usual estimate of sociologists that a mage-earner ought not to pay more than one-fifth of his income for shelter. We find that in Trashington many new houses are being constructed which are sanitary and well arranged and which are offered for sale or for rent at rates which bring them within the reach of skilled laborers and others who receive from $\$ 4$ to $\$ 6$ a day. The two-flat houses described in this report provide suitable accommodations for street-car conductors, motormen, clerks, and others whose income is from $\$ 60$ to $\$ 75$ per month, but the number of flats available at a rental of $\$ 12$ to $\$ 15$ per month is entirely inadequate. The construction of tro-flat houses for this class of wage-earners offer's a safe investment for individuals or companies and should be encouraged.

Tery fer houses or flats have been built during the past five years that are available for unskilled laborers on the basis of one-fifth of their income- $\$ 35$ to $\$ 10$ a month. This class of the population has, therefore, been obliged, to a great extent, to live in old houses, many of which are dilapidated and insanitary, and to orercrowd the available houses to an extent which is incompatible with the requirements of modern civilization. Such orercrowding favors the propagation of infectious diseases and greatly lowers the standard as to health and morality among this unfortunate class of the community.

The day laborer is required to do a long day's work for a low wage and is compelled to accept such shelter as he can pay for. Often this is not only in an insanitary. overcrowded house, but in one which gives to the landlord an exorbitant rate of interest upon the ralue of his property.

To supply every family in the city of Tashington belonging to this class of the population with an independent home, having light and well-rentilated rooms, good plumbing, and all sanitary requirements, would greatly reduce our mortality rates and would no doubt have a marked effect in limiting crime and promoting good morals. But to bring about such ideal conditions would call for the investment of a large amount of money. If it could be shown that the building of this class of houses was a safe and profitable inrestment, it is probable that private enterprise might be relied upon to supply the demand. But, as a matter of fact. private enterprise has not done so. and the reasons for this are rery apparent. T'nder present conditions as to the price of land. of labor, and of materials, and in view of existing building regulations: there is no temptation to capi- 
tal to inrest in this class of houses. The builder of moderate means does not build houses to rent, but to sell. By so doing he makes an immediate profit and his capital is available for further operations. But as a rule those who can only pay $\$ 8$ or $\$ 10$ a month rent can not attempt to purchase a home, and buildings of this class would not be salable unless as an investment paying 6 per cent or more on the cost of the property. Such a return in interest is incompatible with the low rentals named. Then land, labor, and materials were comparatively cheap, and the building regulations were less exacting, two-story houses of frame or brick could be erected on a 12 -foot lot at a cost which made such property a very profitable investment. But under existing regulations the house must have a frontage of at least 16 feet, inside the fire limits the walls must be 13 inches thick, and the foundations, plumbing, etc., must conform to a high standard. We are not disposed to criticise these regulations, but simply desire to point out the fact that they have had the effect of arresting the building of houses of low rental. This arrest of building, taken in connection with the condemnation of old houses and the material increase of the population, has accentuated the house famine and must ineritably lead to an increase in the number of inmates of existing houses, i. e., to overcrowding, with all its evils.

As to the remedy for this condition, it is evident that money is of prime importance. Having the capital, good plans and good management are required in order to obtain the desired result-sanitary houses at low rentals.

Leaving out private enterprise, which we have seen to be inadequate for the relief of the situation, we must rely upon one or all of three methods for obtaining the necessary capital, viz, philanthropy, business philanthropy, or governmental aid.

If a Carnegie or a Rockefeller would invest $\$ 10,000,000$ in the construction of model houses for the poor of the city of Washington, placing the trust in competent hands and devoting the returns received for rent to the construction of additional buildings, the situation would soon be relieved, and we venture to say the resulting benefit to wage-earners and to the community generally would be far greater than could be obtained from the same amount of money invested in libraries or in hospitals.

Business philanthropy requires that the capital available shall be safely invested and shall earn a reasonable rate of interest above all expenses. This calls for careful business management by officers who are influenced by philanthropic motives. We have shown that corporations organized upon this basis may be financially sound and successful when dividends are limited to 4 or 5 per cent. To exact rentals which would give dividends of more than 5 per cent would take a corporation out of the class included under the heading "business philanthropy." And, indeed, the stockholders in such a corporation who have purchased stock after the company was well established can lay little claim to philanthropy on account of their investment. Those, however, who organize, foster, and direct the affairs of such a company from philanthropic motives are certainly entitled to whatever credit may attach to such efforts for the amelioration of the evils of the "house famine." And those who subscribe to the stock' of a company paying less than the prevailing rate of interest 
for the purpose of promoting the welfare of the laboring classes are certainly philanthropists. But experience shows that it is difficult to secure sufficient capital upon this basis to insure important results, and the business philanthropy which succeeds in making the stock of a company attractive from a financial point of view will probably, in the long run, accomplish the most good. Such a company, however, will find it difficult to reduce rentals to the limit we have accepted as a proper expenditure for shelter by the day laborer who only receives $\$ 1.50$ a day, viz, one-fifth of his income.

In England and other European countries this difficulty has been met by government aid. Money is loaned, under proper restrictions, at low rates of interest to promote housing enterprises. Such loans are made by the General Government or by municipalities, and are usually for long periods of time-thirty to fifty years.

It would evidently be impracticable for the General Gorernment in this country to assist towns and cities in all parts of the United States by loans of money for the purpose indicated. This would rather be a function of each municipality. But in the city of Trashington the General Government legislates for the municipality, and we can look nowhere else for assistance of this kind. In the face of a recognized evil which requires large sums of money for its relief, it seems to us that Congress would be justified in appropriating money or in loaning monev, upon proper security, at a low rate of interest for the relief of the situation set forth in this report. The Washington Sanitary Housing Company, which has a charter from Congress limiting its dividends to 4 per cent, has been obliged to discontinue building operations because it does not receive subscriptions to its stock, although a demonstration has been made that this stock is a safe 4 per cent inrestment. If this company, or any other similar organization, could obtain loans from the Government at 3 per cent, the house famine in the national capital could be relieved exactly in proportion to the amount of these loans. Without some such assistance it is difficult to see how existing conditions are to be relieved unless by legislation to prevent overcrowding, so rigidly enforced as to turn away from the city all laborers who are unable to secure proper shelter. This would involve rigid inspection and great hardship to a class of citizens whose services are needed for civic improvements, etc. To force the laborers from the city would lead to the development of suburban slums or the overcrowding of other localities. A scarcity of labor would naturally lead to an increase in wages, and those who remained might thus be able to pay for better houses. But for building operations, street improvements, transportation service, care of buildings, grounds, etc., a large number of laborers are required, and it appears to us to be not only the interest but the duty of the citizens of Washington, the municipal authorities, and the Congress to see to it that sanitary houses are provided for this class of the population in sufficient number to enable them to avoid the evil results of overcrowding and insanitary surroundings. 



